Policy Research Working Paper 2232

Market Access Advances and Retreats

The Uruguay Round and Beyond

J. Michael Finger

Ludger Schuknecht
Uruguay Round negotiations on market access were a success. Tariff cuts covered a larger share of world trade than those of the Kennedy or Tokyo Rounds and will save importers some $\$ 50$ billion a year.

The World Bank

Development Research Group

Trade

November 1999 


\section{Summary findings}

In the Uruguay Round negotiations, trade distorting agricultural policies were taken up substantively for the first time in any round of multilateral trade negotiations. Voluntary export restraints outside the Multifibre Arrangement (MFA) were in fact eliminated.

Developing countries became equal partners with developed countries. Their tariff cuts covered as large a share of imports as those of the developed countries and were deeper. Because developing country tariffs were higher to start with, their cuts will save importers more (per dollar of imports covered) than will cuts by developed countries. Tariff bindings for most developing countries, although often above applied rates, were extended to 90 percent or more of imports.

Few countries agreed to give foreigners unlimited market access in services, or full national treatment in more than a few service activities. But developed countries agreed to some liberalization of cross-border provision for 70 percent of service activities (compared with 25 percent in developing countries).
Less positively, although trade restrictions on agricultural products were converted to tariffs, border protection was reduced less on agricultural than on industrial products, and there was little agreement on reducing trade-affecting subsidies.

The textiles and clothing agreement binds developed countries to eliminate all MFA-sanctioned restrictions but allows them to largely put off doing so until 2005 . Concessions to which developing countries agreed are due now. Reciprocal concessions of particular interest are either due in the future (elimination of the MFA) or yet to be negotiated (liberalization of agricultural trade).

Also disquieting, since the Uruguay Round, developing countries have undertaken antidumping cases at a rate (per dollar of imports) three times higher than that for the United States - mostly against other developing countries.

This paper - a product of Trade, Development Research Group — is part of a larger effort in the group to assess the amount of liberalization which resulted from the Uruguay Round. The research was supported by the Global and Regional Trust Fund component of the World Bank/Netherlands Partnership Program. Copies of the paper are available free from the World Bank, 1818 H Street, NW, Washington, DC 20433. Please contact Lili Tabada, room MC3-333, telephone 202473-6896, fax 202-522-1159, email address ltabada@worldbank.org. Policy Research Working Papers are also posted on the Web at www.worldbank.org/research/workingpapers. Michael Finger may be contacted at jfinger@worldbank.org. November 1999. (69 pages)

The Policy Research Working Paper Series disseminates the findings of work in progress to encourage the exchange of ideas about development issues. An objective of the series is to get the findings out quickly, even if the presentations are less than fully polished. The papers carry the names of the authors and should be cited accordingly. The findings, interpretations, and conclusions expressed in this paper are entirely those of the authors. They do not necessarily represent the view of the World Bank, its Executive Directors, or the countries they represent. 


\title{
MARKET ACCESS ADVANCES AND RETREATS: THE URUGUAY ROUND AND BEYOND
}

\author{
J. Michael Finger
}

(The World Bank)

and

\section{Ludger Schuknecht}

(World Trade Organization)

We are most grateful to Felix Eschenbach for very valuable research assistance. We would also like to thank Rolf Adlung, Alberto Campeas, Janet Chakarian-Renouf, Stephane Choremi, Bill Davy, Sameena Dost, Marianna Gagliardi, Jessy Kreier, David Hartridge, Markus Jelitto, Jean-Pierre Lapalme, Denby Misurelli, Heinz Opels, Maria Rosa Perrin, Suja Rishikesh-Mavroides, Andras Szepesi, Raul Torres, and Frank Wolter for their great help and numerous comments in compiling this study. 



\section{TABLE OF CONTENTS}

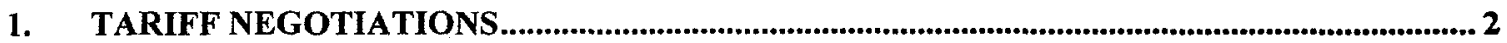

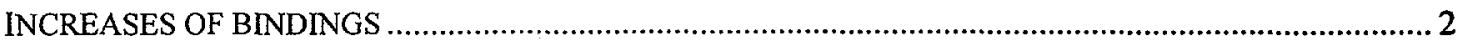

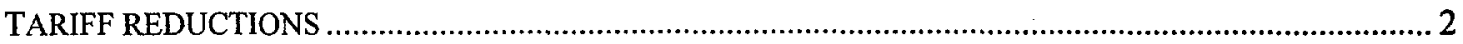

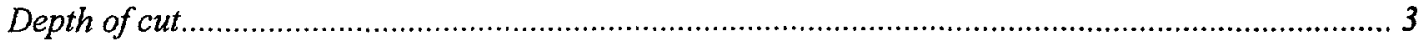

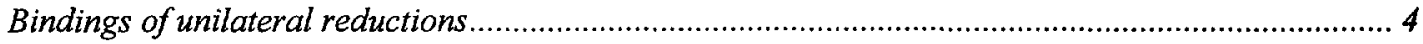

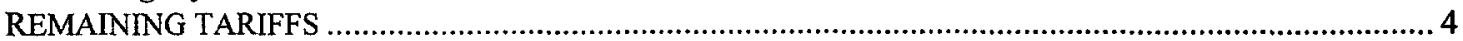

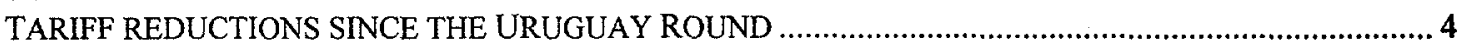

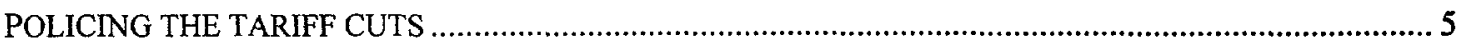

TABLE T1: URUGUAY ROUND TARIFF CONCESSIONS GIVEN AND RECEIVED ................................. 6

TABLE T2: POST-URUGUAY ROUND TARIFF RATES, ALL MERCHANDISE ....................................... 7

TABLE T3: URUGUAY ROUND TOTAL, BOUND AND RECIPROCAL REDUCTIONS OF SELECTED

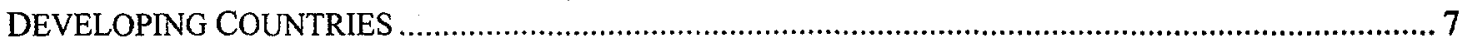

TABLE T4: POST-URUGUAY ROUND TARIFF CONCESSIONS ..................................................... 8

CHART T1: COVERAGE OF GATT TARIFF BINDINGS, PRE- AND POST-URUGUAY ROUND ..............9

CHART T2: DEPTH OF TARIFF CUTS AGREED AT THE URUGUAY ROUND ..................................... 10

CHART T3: POST-URUGUAY ROUND MFN TARIFFS OF DEVELOPING AND OF INDUSTRIAL

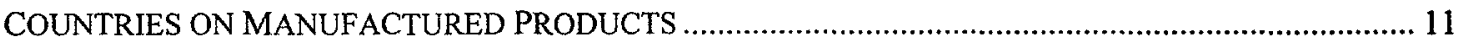

2. QUANTITATIVE RESTRICTIONS ........................................................................................... 12

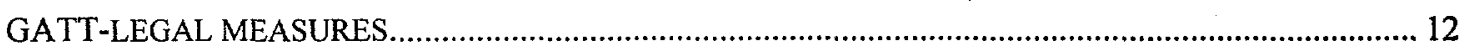

MEASURES NOTIFIED FOR POST-URUGUAY ROUND ELIMINATION ….......................................... 13

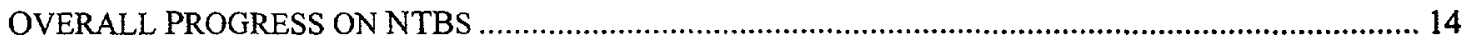

TABLE QR1: INDICATIVE LIST OF NOTIFICATIONS OF GATT-CONSISTENT* QUANTITATIVE

RESTRICTIONS AND JUSTIFICATIONS, BY MEMBER ……............................................................. 15

TABLE QR2: PRE-EXISTING MEASURES NOTIFIED BY MEMBERS AS SUBJECT TO ELIMINATION

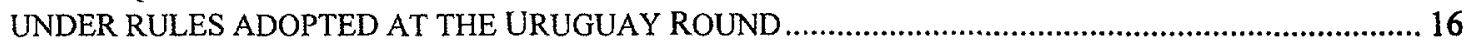

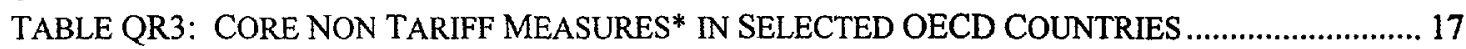

TABLE QR4 CORE NON-TARIFF MEASURES IN SELECTED DEVELOPING ECONOMIES.................... 18

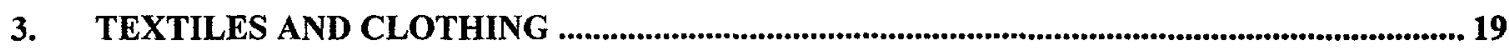

IMPLEMENTATION - CONCENTRATED ON RELATIVELY UNRESTRICTED PRODUCTS .....................20

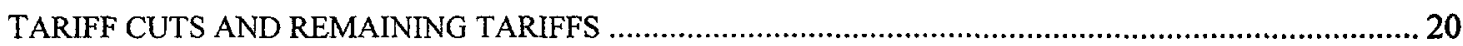

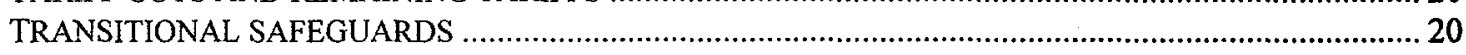

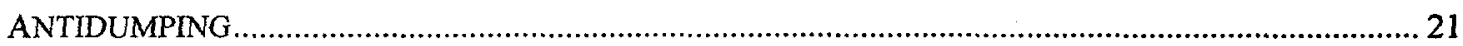

TABLE TC1: NUMBERS OF MFA QUOTA LIMITS NOTIFIED AND ELIMINATED IN STAGES 1 AND 2

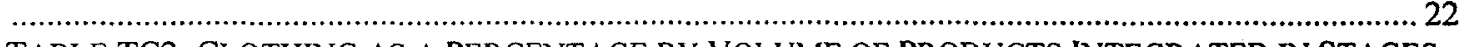

TABLE TC2: CLOTHING AS A PERCENTAGE BY VOLUME OF PRODUCTS INTEGRATED IN STAGES

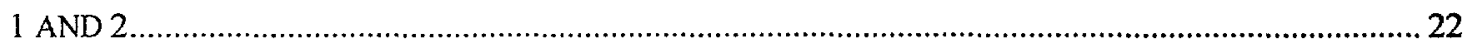

TABLE TC3: POST URUGUAY ROUND APPLIED TARIFF RATES AND URUGUAY ROUND TARIFF

CUTS ON TEXTILES AND CLOTHING AND ON ALL INDUSTRIAL GOODS …….................................23

TABLE TC4: TRANSITIONAL SAFEGUARDS IN TEXTILES AND CLOTHING SINCE $1 / 95 . . . \ldots . . . . . . . . . . . .24$

4. AGRICULTURE ................................................................................................................................ 29

THE INTENT OF THE NEGOTIATORS

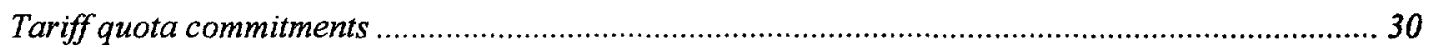

ESTIMATING HOW THE AGREEMENT HAS CHANGED MARKET ACCESS ….................................... 30

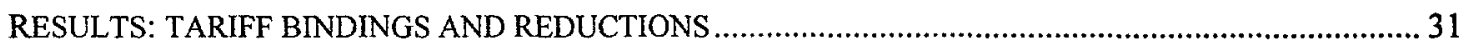

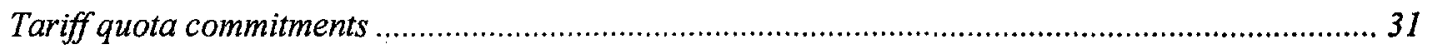

TARIFFICATION ABOVE EXISTING LEVELS OF PROTECTION ............................................................. 32

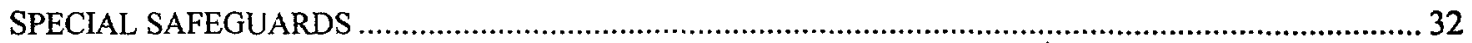

TABLE A1: AGRICULTURAL PRODUCTS: URUGUAY ROUND TARIFF BINDINGS …………….......... 33 
TABLE A2: AVERAGE URUGUAY ROUND TARIFF CUTS ON AGRICULTURAL PRODUCTS, AVERAGE POST-URUGUAY ROUND APPLIED AND BOUND TARIFF LEVELS .

CHART A I: COMPARISONS OF EXTENT AND DEPTH OF UR TARIFF CONCESSIONS ON

AGRICULTURAL PRODUCTS, OF POST-UR BOUND RATES BY DEVELOPED AND BY DEVELOPING

ECONOMIES

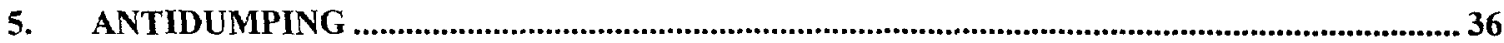

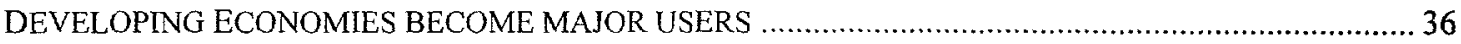

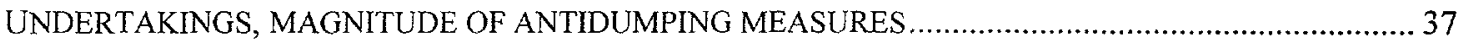

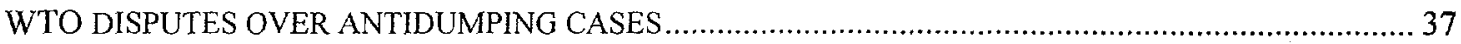

ANTIDUMPING AS AFFECTED BY THE ASIAN CRISIS ……........................................................ 38

ANTIDUMPING CASES IN SECTORS WITH NOTABLE LIBERALIZATION ..........................................38

TABLE AD1: ANTIDUMPING INITIATIONS BY ECONOMY TAKING ACTION …................................ 39

TABLE AD2: ANTIDUMPING INITIATIONS BY EXPORTING ECONOMY ........................................... 40

TABLE AD3: SHARE OF COMPLETED INVESTIGATIONS RESULTING IN PROVISIONAL AND

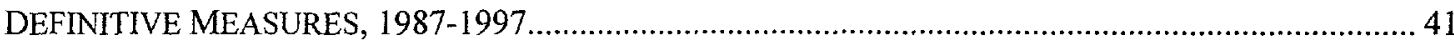

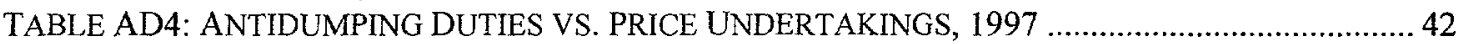

TABLE AD5: ANTIDUMPING INITIATIONS AGAINST SOUTH-EAST ASIAN COUNTRIES IN 1997 AND

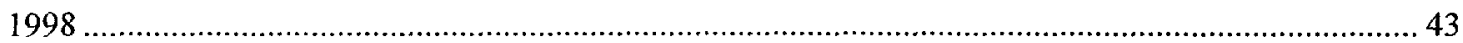

TABLE AD6: ANTIDUMPING CLAIMS BY SECTORS WITH ABOVE AVERAGE LIBERALIZATION,

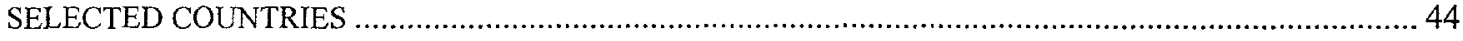

CHART AD1: ANTIDUMPING -TOTAL NUMBER OF INITIATED INVESTIGATIONS, ALL WTO

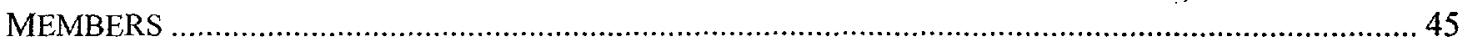

CHART AD2: NUMBERS OF ANTIDUMPING INITIATIONS BY DEVELOPED AND BY DEVELOPING

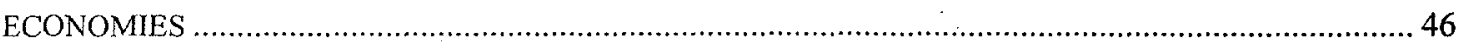

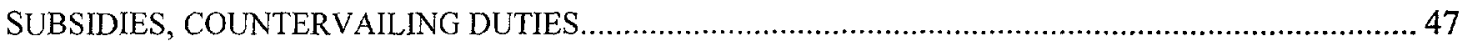

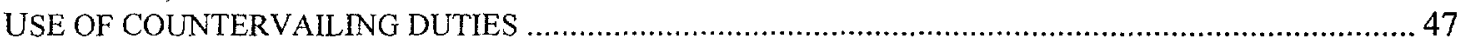

TABLE CV1: NUMBERS OF INITIATIONS OF COUNTERVAILING DUTY INVESTIGATIONS, BY

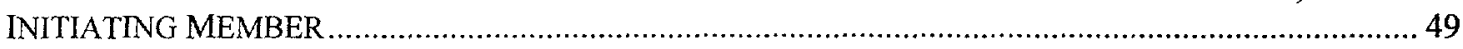

TABLE CV2: NUMBERS OF INITIATIONS OF COUNTERVAILING DUTY INVESTIGATIONS, BY

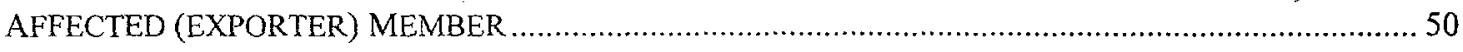

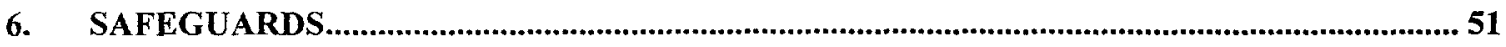

TABLE SG1: SAFEGUARD INVESTIGATIONS INITIATIONS, 1991-1998_.........................................52

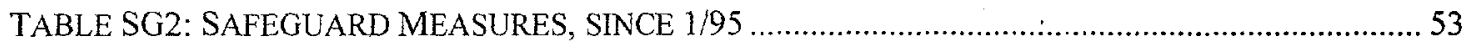

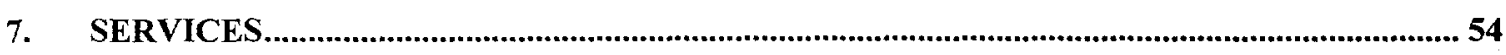

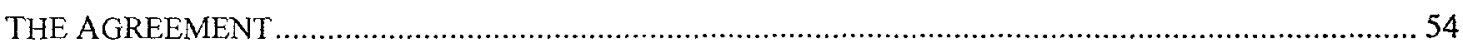

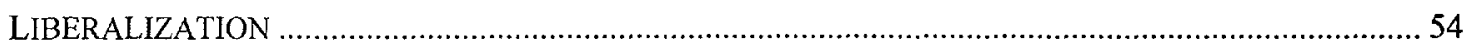

TABLE S1: MODE 1 COMMITMENTS IN SELECTED SERVICES SECTORS …..................................57

TABLE S2: MODE 3 COMMITMENTS IN SELECTED SERVICES SECTORS ......................................... 58

TABLE S3: PERCENTAGES OF DEVELOPING AND OF DEVELOPED ECONOMIES THAT GAVE FULL

MARKET ACCESS OR FULL NATIONAL TREATMENT COMMITMENTS ON SELECTED SERVICE

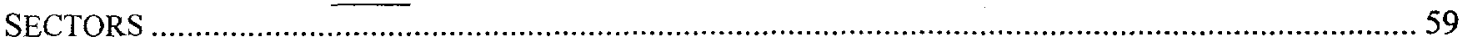

TABLE S4: PERCENTAGES OF DEVELOPING AND OF DEVELOPED ECONOMIES THAT MADE SOME MARKET ACCESS OR SOME NATIONAL TREATMENT COMMITMENTS ON SELECTED SERVICE

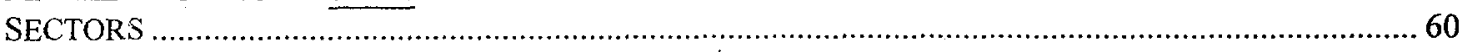

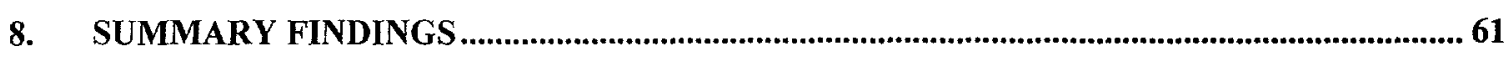

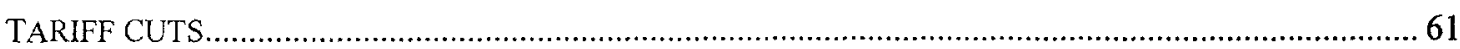

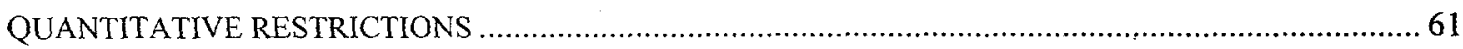

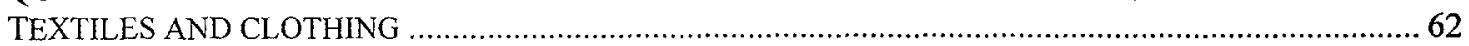

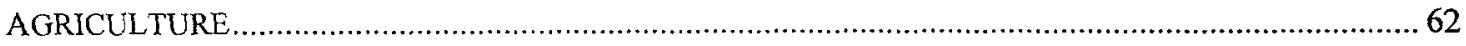

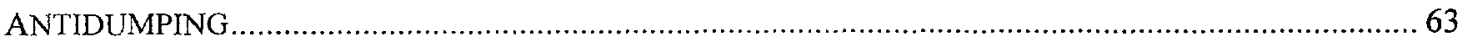

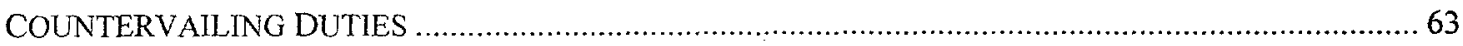

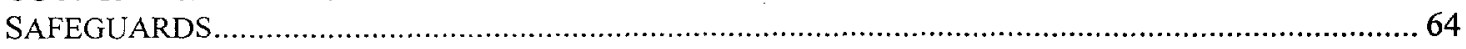

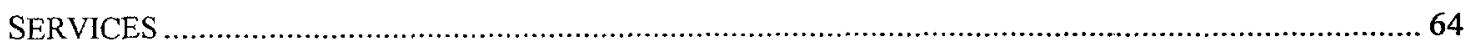


TABLE SF1: TARIFF CONCESSIONS AND LEVELS ON ALL MERCHANDISE, INDUSTRIAL GOODS, TEXTILES AND CLOTHING, AGRICULTURAL PRODUCTS - DEVELOPED ECONOMIES AND

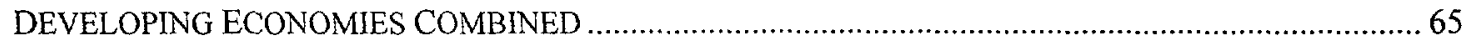

TABLE SF3: POST URUGUAY ROUND TARIFF RATES DEVELOPED ECONOMIES AND DEVELOPING

ECONOMIES -PERCENT AD VALOREM...................................................................................... 65

TABLE SF2: SUMMARY OF URUGUAY ROUND CONCESSIONS BY DEVELOPED ECONOMIES AND

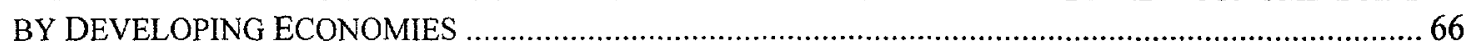

TABLE SF4: PERCENTAGES OF ANTIDUMPING INITIATIONS, JULY 1996 - JUNE 1998 AGAINST

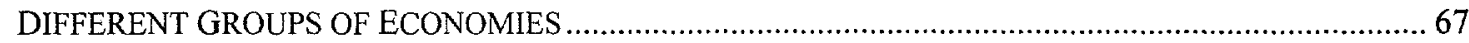

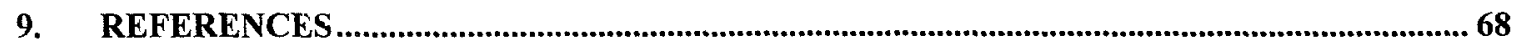





\title{
Market Access Advances and Retreats Since the Uruguay Round Agreement
}

\author{
by \\ J. Michael Finger and Ludger Schuknecht
}

The Uruguay Round has been justly celebrated for the innovations it represents: coverage extended to services, intellectual property, trade-related investment issues, much greater attention to the rules of trade-policy making and administration, a new and unified organization to administer the agreements. At the same time, the Uruguay Round dealt significantly with the more or less traditional subject of the GATT - market access: tariff cuts as broad in scope as those of any previous round were agreed, policies that affect trade in agricultural products were taken up for the first time, agreement was reached to eliminate restrictions on trade in textiles and clothing under the Multi-Fiber Arrangement. ${ }^{2}$ This paper deals only with market access. In it we present a tally of:

- implementation of market access commitments, i.e., of the agreed removal or reduction of import restrictions and,

- use of various "safeguard" and other measures that the agreement provides that allow a member government to introduce new trade restrictions.

Our report thus has no thesis to advance, it is not an essay, it is a tabulation of the amount of liberalization that has resulted from the Uruguay Round Agreements, and of slippage from that liberalization. Our objective is not to count up to see which part is larger, the agreed liberalization versus the allowed "backsliding." No doubt, the liberalization has been larger, by several orders of magnitude. Nevertheless, it is important to keep a close watch on the use of allowed backsliding.

Our major findings are the following:

1. Much was achieved. Tariff cuts compare well to the coverage and depth of cuts achieved at the Tokyo and Kennedy Rounds. Agricultural protection was dealt with substantively for the first time, VERs outside of MFA have been phased out. The agreement to remove MFAbased quantitative restrictions on imports of textiles and clothing is of itself a major accomplishment.

2. There has been minimal backsliding, minimal use of the special or general provisions for imposing new restrictions that the various WTO agreements provide. Antidumping is the one exception.

3. Tariff cuts by developing countries were as broad and at the same time, deeper, than those conceded by the developed economies.

4. The major part of what developing economies gave is due now, the major part of what they receive will not be delivered until 2005 , or is yet to be negotiated. What they gave (apart from the exchange of tariff cuts) was mainly acceptance of "codes" on major areas of

\footnotetext{
${ }^{2}$ We do not review in this paper these "rules" areas of the Uruguay Round agreements. They are taken up in J. Michael Finger and Philip Schuler, "Implementation of Uruguay Round Commitments: The Development Challenge," World Bank Staff Working Paper, forthcoming.
} 
domestic as well as import regulation/institutions (e.g., intellectual property, technical and sanitary standards, customs valuation, import licensing procedures). What they got in return from the developed economies is MFA elimination - not due until 2005 - trade liberalization and reduction of domestic support on agricultural products - yet to be negotiated. Details are provided below.

\section{TARIFF NEGOTIATIONS}

At the Uruguay Round, some 130 countries or customs areas made tariff concessions. Within the mechanics of the GATT/WTO, a member makes a concession by submitting to the organization a schedule of commitments, of bound rates. In doing so, the member accepts a legal obligation not to impose a duty on any listed product at a rate higher than the specified bound rate. Its schedule of bound rates defines a member's legal obligations on tariff rates there was no legal commitment to cut tariffs by a specified amount and thus no "official" measure of the tariff reductions exchanged at the Round.

As the negotiations matured, a frequently mentioned "target" was that developed members should reduce their tariffs by one-third, developing members should reduce theirs by one fourth. The discussion surrounding these targets was not precise, e.g., as to whether the base should be all merchandise imports or only industrial goods, all tariff lines vs. all dutiable tariff lines, or even if the appropriate formula was $\mathrm{dT} / \mathrm{T}$ or $\mathrm{dT} /(1+\mathrm{T})$. Members also engaged in a related discussion of how bindings of unilateral liberalizations would be treated, all of this complicated by an imprecision as to what date should be used to determine the "before" tariff rates.

In Table T1 along with Charts T1 and T2, we summarize our measures of the increase of bindings and the tariff reductions that will result from Uruguay Round commitments. ${ }^{3}$

\section{INCREASES OF BINDINGS}

Expansions of bindings are simple to conceptualize - the amount of some base year's imports that would be covered by the new bindings versus the old. Increased bindings by developing economies are evident from Chart T1. Developing economies sometimes bound tariffs at levels above currently applied rates and some members' tariff concessions consisted of binding tariffs at rates to which they had previously been reduced unilaterally. More information will be provided below both on ceiling bindings and on bindings of unilateral concessions.

\section{TARIFF REDUCTIONS}

We find that Uruguay Round commitments by the developing economies to reduce their tariffs compare well with the commitments of the developed economies.

- developing economies' tariff cuts cover approximately the same percentage of imports,

- developing economies' tariff cuts are actually deeper.

\footnotetext{
3Though we use here the labels "developed" and "developing," the classification of countries used in these calculations is the World Bank's sorting of countries as either high-income economies (HIES) or low and middle income economies (LMIEs), that includes transition economies. The following footnote provides details of country coverage of the two categories.
} 


\section{Depth of cut ${ }^{4}$}

Our calculations of depth of tariff cut depart in two ways from the way that the GATT tariff cuts are traditionally measured. First, GATT tariff cuts are usually measured only over the import categories on which cuts are made; e.g., "a 30\% cut on $40 \%$ of imports" does not mean that the tariff, on average, is now 30 percent lower. It means that the tariff is, on average, $.4 \mathrm{x}$ $30 \%$, or 12 percent lower. We include "zero cuts" in our average. 5

Second, it is obvious that a 50 percent reduction of a $2 \%$ tariff rate does not improve market access the same as cutting a $40 \%$ rate in half. Taking this into account, we have calculated tariff changes from the formula

$$
\mathrm{dT} /(1+\mathrm{T})
$$

where $\mathrm{T}$ is the ad valorem tariff rate, or ad valorem equivalent. From the perspective of an exporter, $\mathrm{dT} /(1+\mathrm{T})$ measures the percentage by which she can reduce her delivered price in the importing country while keeping the net price she collects (after the tariff) the same. This comes to less than 1 percent if a $2 \%$ rate is cut in half, to more than 14 percent if a $40 \%$ rate is cut in half. We consider, thus, the formula $\mathrm{dT} /(1+\mathrm{T})$ to provide the more appropriate measure of market access improvement.

Because of the tariff cuts, exporters on average will be able to reduce an additional 1 percent of what buyers pay in developed economies, 2.3 percent more of what buyers pay in developing economies. These figures are less exciting that reports of "tariffs being cut worldwide by an average of 40 percent," that were in newspapers the day after the agreement was completed. $^{6}$

Generally, the tariff cuts were made in five annual stages, the last on January 1, 1999. There were some exceptions in each direction, toward quicker implementation and toward slower.

\footnotetext{
${ }^{4}$ The results reported in this section come in large part from Finger, Ingco and Reincke. That source provides more extensive information on tariff concessions given and received by major Uruguay Round participants. Finger, Ingco and Reincke also provide a detailed discussion of which date were taken as the "before" and the "after" Uruguay Round tariff rates. Conceptualization of "before" and "after" followed practice developed by the GATT/WTO Secretariat, the dominant concern being to isolate tariff cuts that took place as a result of Uruguay Round commitments, not to count politically unilateral tariff cuts that took place while the round was under way. The basic data source for Finger, Ingco and Reincke is the GATT/WTO Integrated Data Base (IDB) that provides electronic data on the Uruguay Round schedules of commitments plus corresponding trade data for 40 major participants in the Uruguay Round negotiations (counting the then 12 members of the European Union as one participant).

The IDB covers 98 percent of merchandise (excluding petroleum) imports of the GATT contracting parties at the time of the round. Finger, Ingco and Reincke followed the World Bank convention of dividing economies into high income vs. low and middle income. By this classification, the IDB covers 14 high-income economies plus 26 "transition" and "developing" economies. With the exception of Hong Kong, all of the countries classified as high income are OECD members. Mexico and Korea, though OECD members, are classified as developing countries.

${ }^{s}$ That we are focusing on market access may seem an obvious point, but experience with previous drafts indicates that readers will view our information from different perspectives. Some, for example, have commented that in calculating the percentage of imports subject to tariff cuts, we should have excluded already duty-free imports from the denominator - that a country with 80 percent duty free imports at the beginning could not have done more than make cuts on 20 percent. Our figures compare the percentage of countries' imports affected by Uruguay Round concessions, on who did what. They do not compare who was more generous, who might have done what, or who tried harder.

${ }^{6}$ The quote in this sentence is from the Financial Times, December 16, 1993, page 1.
} 


\section{Bindings of unilateral reductions}

Table T3 reports for selected countries the percentage of recent tariff reductions that have been bound at the Uruguay Round. ${ }^{7}$ The countries in Table T3 are not the only countries that implemented unilateral liberalizations, they are the countries for which we could find data to measure the unilateral tariff liberalization, as well as the reduction agreed at the Uruguay Round.

Overall, our figures show that the countries in the group have bound somewhat less than half of the unilateral concessions that they have implemented since 1986. Measured by the $\mathrm{dT} /(1+\mathrm{T})$ formula, that comes to a bound cut of 8 to 12 percent for a number of Latin American countries and a 22 percent cut for India. Again, such figures compare favorably with the tariff cuts agreed and bound by the developed economies at the Uruguay Round.

\section{REMAINING TARIFFS}

Table $\mathrm{T} 2$ presents post Uruguay Round averages of bound and of applied rates. Even though the developing economies agreed to larger cuts at the Uruguay Round, and a number of them also implemented unilateral reductions, their tariffs are still on average considerably higher than those of the developed economies.

Chart T3 provides the same information graphically. Generally, remaining patterns of tariff protection have the following characteristics:

1. Tariffs are disproportionally imposed against the exports of developing economies.

2. Tariffs are disproportionally imposed by the developing economies.

3. Biases against developing country exports are in developing economies' tariffs as much as in the developed economies' tariffs.

Beneath the low average tariffs of the developed economies there remain some significant tariff peaks, i.e., rates which are more than three times the national average. In several developed economies more than 10 percent of tariff lines bear rates more than three times as high as the national average. (Laird, 1999). The sectors with such peaks tend to be those of greater export interest to developing economies: footwear, leather and leather goods, food products, agriculture and textiles/clothing (UNCTAD/WTO, 1998) (a separate discussion of these latter product categories follows below). Both developing and developed economies display this tendency to impose higher import duties on goods of particular export interest to developing economies. That is why we see the pattern that Chart $\mathrm{T} 3$ reports.

\section{TARIFF REDUCTIONS SINCE THE URUGUAY ROUND}

WTO members at several negotiations since the Uruguay Round have agreed to significant further tariff reductions (Table T4). The largest of these reductions came together in the Ministerial Declaration on Trade in Information Technology Products which by the fall of

\footnotetext{
${ }^{7}$ These results are taken from Finger and Winters (1998). The data that were used and the formulas for calculating total, bound and reciprocal reductions are explained there. Intuitively, suppose an applied tariff rate, initially $50 \%$, is reduced in a unilateral liberalization to $20 \%$. Suppose the country also agrees to bind the rate on that tariff line at $30 \%$. The Total reduction is (50-20) or 30 percentage points; the Bound Reduction is (50-30) or 20 percentage points. The Reciprocal Reduction, the reduction conditioned on the Uruguay Round, is what the Uruguay Round adds to the Total Reduction. In this example, the bound rate is above the unilaterally assigned applied rate, so the Reciprocal Reduction is zero. Had the Uruguay Round bound rate been $10 \%$, the Total Reduction would be (50-10), the Bound reduction would be (50-10) and the Reciprocal Reduction would be (20-10).
} 
1997 had accumulated 43 signatories who thereby committed to a stepwise tariff elimination on an MFN basis - on information technology products. ${ }^{8}$

This liberalization is impressive in both scope and depth. The Information Technology Agreement covers some big items like semiconductors, computers, scientific instruments and software - in 1997, more than 10 percent of world merchandise trade. Uruguay Round tariff cuts, we noted above, covered about 30 percent of world merchandise trade. The tariffs in question are more or less in line with the averages in most of the countries involved, hence the depth of cut will be in the same range as the depth of the Uruguay Round cuts.

Another post-Uruguay Round liberalization involved Canada, the European Union, Japan, Macau, Switzerland-Liechtenstein, and the US who agreed to eliminate tariffs by April 1997 on 465 pharmaceutical products, and on another 639 products by July 1999 . These negotiated tariff eliminations followed an understanding during the Uruguay Round to hold such negotiating meetings at least every three years. These eliminations come in addition to 6,000 duty-free products already covered under the pharmaceutical initiative in the Uruguay Round.

The third instance, the EU and the US agreed in 1997 to reduce tariffs on distilled spirits, with the objective of eliminating tariffs on most of these products by 2000 .

\section{POLICING THE TARIFF CUTS}

WTO Members created no specific mechanism to monitor the implementation tariff commitments. "Monitoring" will be done by traders - if a trader is asked to pay a duty above the importing country's bound rate, the trader's government can take the situation to the WTO dispute settlement process. As of March 1999, only one such situation has been brought to WTO dispute settlement, and the case is now under consultation.

The Integrated Data Base ${ }^{9}$ itself is an important instrument for monitoring implementation of tariff commitments and increasing the transparency of tariff protection. The IDB was first pulled together to aid negotiators during the Uruguay Round. Since July 1997, members are required ${ }^{10}$ to notify annually bound and applied tariff rates plus annual import statistics at the tariff line level. As of January 1999, 52 countries had made submissions to the IDB and a further 7 had requested technical assistance to do so. Submissions however were not always complete, bound rates have been included in only 33 of the 52 submissions. ${ }^{11}$

\footnotetext{
${ }^{8}$ For most of the signatories, tariffs will be eliminated by January 2000, for a few, by January 2005.

${ }^{9}$ The IDB is an electronic database. All Members have submitted (at least) paper copies of their schedules of commitments.

${ }^{10}$ General Council decision of 16 July 1997 (WT/L/225).

${ }^{11}$ Adapting data to recent changes and the technical challenge of producing submissions for 8 or 10 thousand tariff lines are the major reasons for delays.
} 
TABLE T1: URUGUAY ROUND TARIFF CONCESSIONS GIVEN AND RECEIVED

\begin{tabular}{|c|c|c|c|c|}
\hline & \multirow{2}{*}{\multicolumn{2}{|c|}{$\begin{array}{l}\text { Bindings } \\
\text { (percentage of } 1989 \text { imports) }\end{array}$}} & \multicolumn{2}{|c|}{ Tariff reductions } \\
\hline & & & \multirow[b]{2}{*}{$\%$ of imports } & \multirow{2}{*}{$\begin{array}{l}\text { Depth of cut } \\
(\mathrm{dT} /(1+\mathrm{T})\end{array}$} \\
\hline & pre-UR & post-UR & & \\
\hline \multicolumn{5}{|l|}{ Tariff Concessions Given - All merchandise } \\
\hline Developed Economies & 80 & 89 & 30 & 1.0 \\
\hline Developing Economies & 30 & 81 & 29 & 2.3 \\
\hline All & 73 & 87 & 30 & 1.2 \\
\hline \multicolumn{5}{|l|}{ Tariff Concessions Received - All merchandise } \\
\hline Developed Economies & 77 & 91 & 36 & 1.4 \\
\hline Developing Economies & 64 & 78 & 28 & 1.0 \\
\hline \multirow[t]{3}{*}{ All } & 73 & 87 & 33 & 1.3 \\
\hline & \multirow{2}{*}{\multicolumn{2}{|c|}{$\begin{array}{l}\text { Bindings } \\
\text { (percentage of } 1989 \text { imports) }\end{array}$}} & \multicolumn{2}{|c|}{ Tariff reductions } \\
\hline & & & \multirow[b]{2}{*}{$\%$ of imports } & \multirow{2}{*}{$\begin{array}{l}\text { Depth of cut } \\
(\mathrm{dT} /(1+\mathrm{T})\end{array}$} \\
\hline Tariff Concessions Given - Industrial goods & pre-UR & post-UR & & \\
\hline Developed Economies & 85 & 92 & 32 & 1 \\
\hline Developing Economies & 32 & 84 & 33 & 2.7 \\
\hline \multirow[t]{3}{*}{ All } & 77 & 91 & 32 & 1.3 \\
\hline & \multirow{2}{*}{\multicolumn{2}{|c|}{$\begin{array}{c}\text { Bindings } \\
\text { (percentage of } 1989 \text { imports) } \\
\end{array}$}} & \multicolumn{2}{|c|}{ Tariff reductions } \\
\hline & & & \multirow[b]{2}{*}{$\%$ of imports } & \multirow{2}{*}{$\begin{array}{l}\text { Depth of cut } \\
(\mathrm{dT} /(1+\mathrm{T})\end{array}$} \\
\hline Tariff Concessions Received - Industrial goods & pre-UR & post-UR & & \\
\hline Developed Economies & 79 & 93 & 37 & 1.5 \\
\hline Developing Economies & 72 & 86 & 36 & 1.2 \\
\hline All & 77 & 91 & 37 & 1.4 \\
\hline
\end{tabular}


TABle T2: Post-Uruguay Round Tariff Rates, ALl MERCHANDiSe

\begin{tabular}{|l|c|c|c|}
\hline & $\begin{array}{c}\text { Bound rate, } \\
\text { Average ad } \\
\text { valorem }\end{array}$ & $\begin{array}{c}\text { post-UR bound } \\
\text { rate above } \\
\text { applied rate }^{\mathbf{a}}\end{array}$ & $\begin{array}{c}\text { applied rate, } \\
\text { average ad } \\
\text { valorem }\end{array}$ \\
\hline Developed Economies & 3.5 & 19 & 2.6 \\
\hline Developing Economies & 25.2 & 37 & 13.3 \\
\hline All & 6.5 & 22 & 4.3 \\
\hline
\end{tabular}

${ }^{\mathrm{a}}$ Percentage of 1989 imports.

TABLE T3: URUGUAY ROUND TOTAL, BOUND AND RECIPROCAL REDUCTIONS OF SELECTED DEVELOPING COUNTRIES

\begin{tabular}{|l|c|c|c|c|}
\hline \multicolumn{1}{|c|}{ Country } & $\begin{array}{c}\text { Total } \\
\text { Reduction }\end{array}$ & $\begin{array}{c}\text { Bound } \\
\text { Reduction }\end{array}$ & $\begin{array}{c}\text { Reciprocal } \\
\text { Reduction }\end{array}$ & $\begin{array}{c}\text { Percentage of } \\
\text { Total } \\
\text { Reduction } \\
\text { Bound }\end{array}$ \\
\hline Argentina & 16 & 9 & .001 & 57 \\
\hline Brazil & 25 & 12 & .007 & 47 \\
\hline Chile & 19 & 8 & 0 & 39 \\
\hline Mexico & 27 & 8 & .004 & 30 \\
\hline Peru & 20 & 9 & .03 & 46 \\
\hline Uruguay & 6 & 3 & .009 & 41 \\
\hline Venezuela & 19 & 2 & 0.2 & 12 \\
\hline India & 27 & 22 & 4.8 & 82 \\
\hline \multicolumn{4}{|l}{} \\
\hline
\end{tabular}


TABle T4: Post-Uruguay Round TaRiff Concessions

\begin{tabular}{|l|l|l|l|}
\hline \multicolumn{1}{|c|}{ Products } & \multicolumn{1}{|c|}{ Countries } & \multicolumn{1}{c|}{ Concessions } & \multicolumn{1}{c|}{ Trade covered } \\
\hline $\begin{array}{l}\text { Pharmaceutical } \\
\text { products }\end{array}$ & $\begin{array}{l}\text { Canada, EC, Japan, } \\
\text { Macao, } \\
\text { Switzerland/Liechtenstein } \\
\text { USA }\end{array}$ & $\begin{array}{l}\text { Duty free treatment for } \\
\text { 465 pharmaceutical } \\
\text { products from 4/97 and } \\
\text { for another 639 products } \\
\text { from 7/99. At the } \\
\text { Uruguay Round, these } \\
\text { members agreed to duty } \\
\text { free treatment of some } \\
6000 \text { products. }\end{array}$ & $\ldots$ \\
\hline $\begin{array}{l}\text { Information } \\
\text { technology } \\
\text { products }\end{array}$ & $\begin{array}{l}\text { 43 WTO Members and } \\
\text { acceding Members }\end{array}$ & $\begin{array}{l}\text { Stepwise elimination of } \\
\text { tariffs on information } \\
\text { technology products until } \\
\text { January 2000, selected } \\
\text { countries until 2005 see } \\
\text { ITA for product cover) }\end{array}$ & $\begin{array}{l}\text { Covers about 10\% } \\
\text { percent of world } \\
\text { trade in IT products } \\
\text { of US\$ 500 billion } \\
\text { in 1997 }\end{array}$ \\
\hline Distilled spirits & USA, EC & $\begin{array}{l}\text { Tariff reductions for } \\
\text { distilled spirits in 1997; } \\
\text { most tariffs will be } \\
\text { reduced to zero by 2000 }\end{array}$ & $\ldots$ \\
\hline
\end{tabular}

Source: Rectifications and Modifications of Uruguay Round Schedules 
Chart T1: Coverage of GATT TARIfF Bindings, Pre- AND Post-URuguay Round

(Industrial Goods)

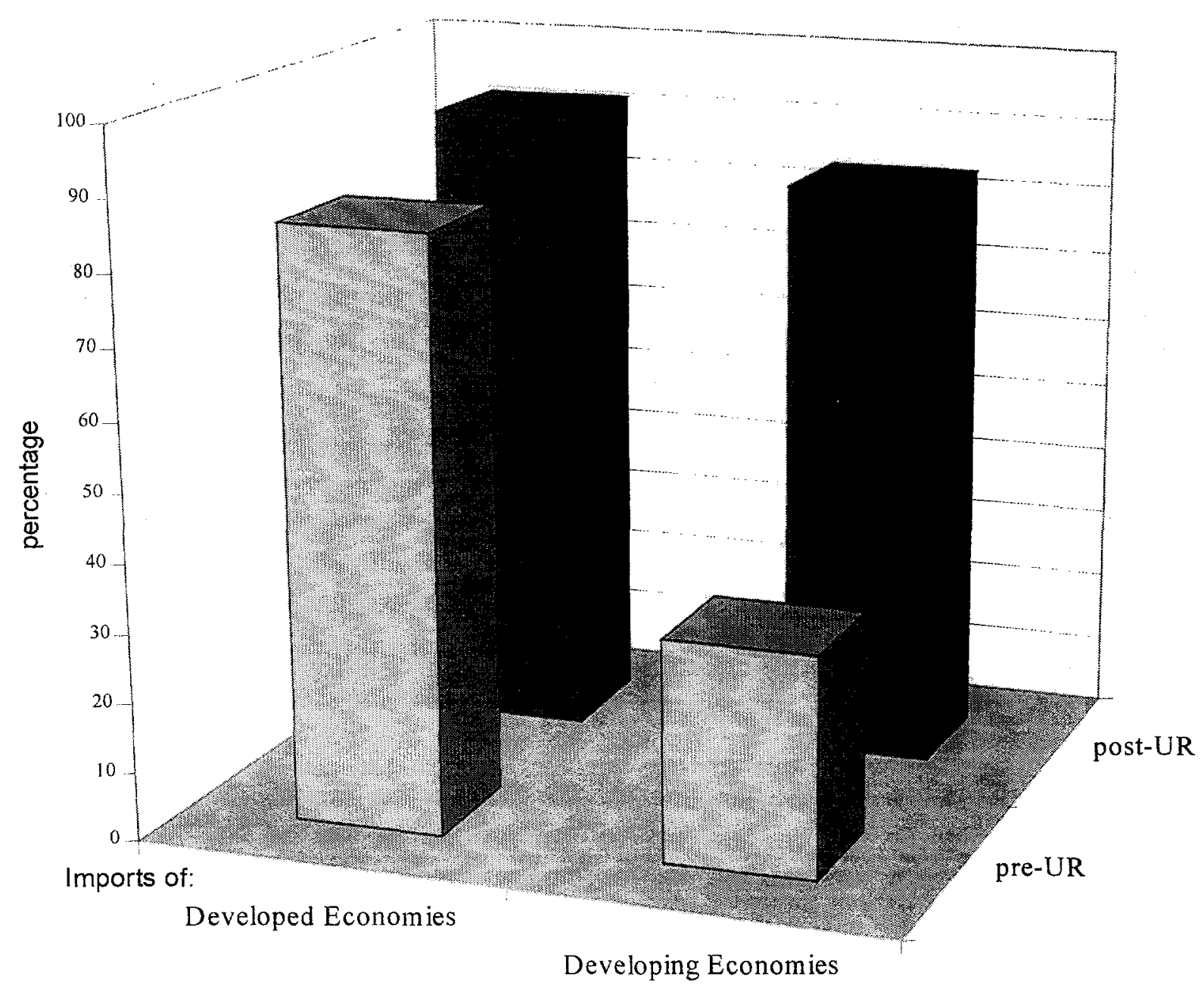


CHART T2: DEPTH OF TARIFF CUTS AGREED AT THE URUGUAY ROUND

(Industrial Goods)

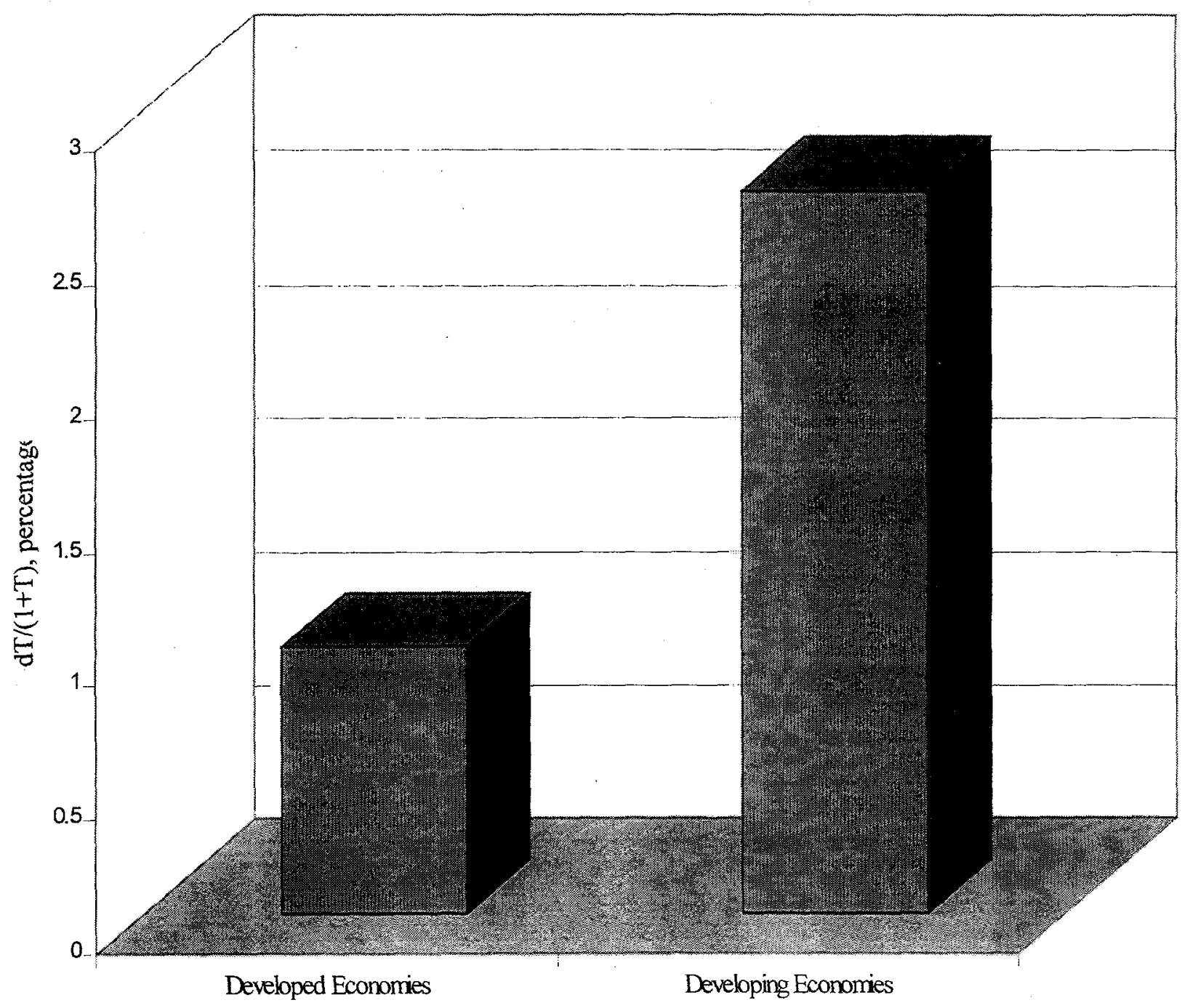


Chart T3: POST-URUgUay RoUnd MFN TARIFFS OF DEVELOPING AND OF INDUSTRIAL COUNTRIES ON MANUFACTUREd PRODUCTS

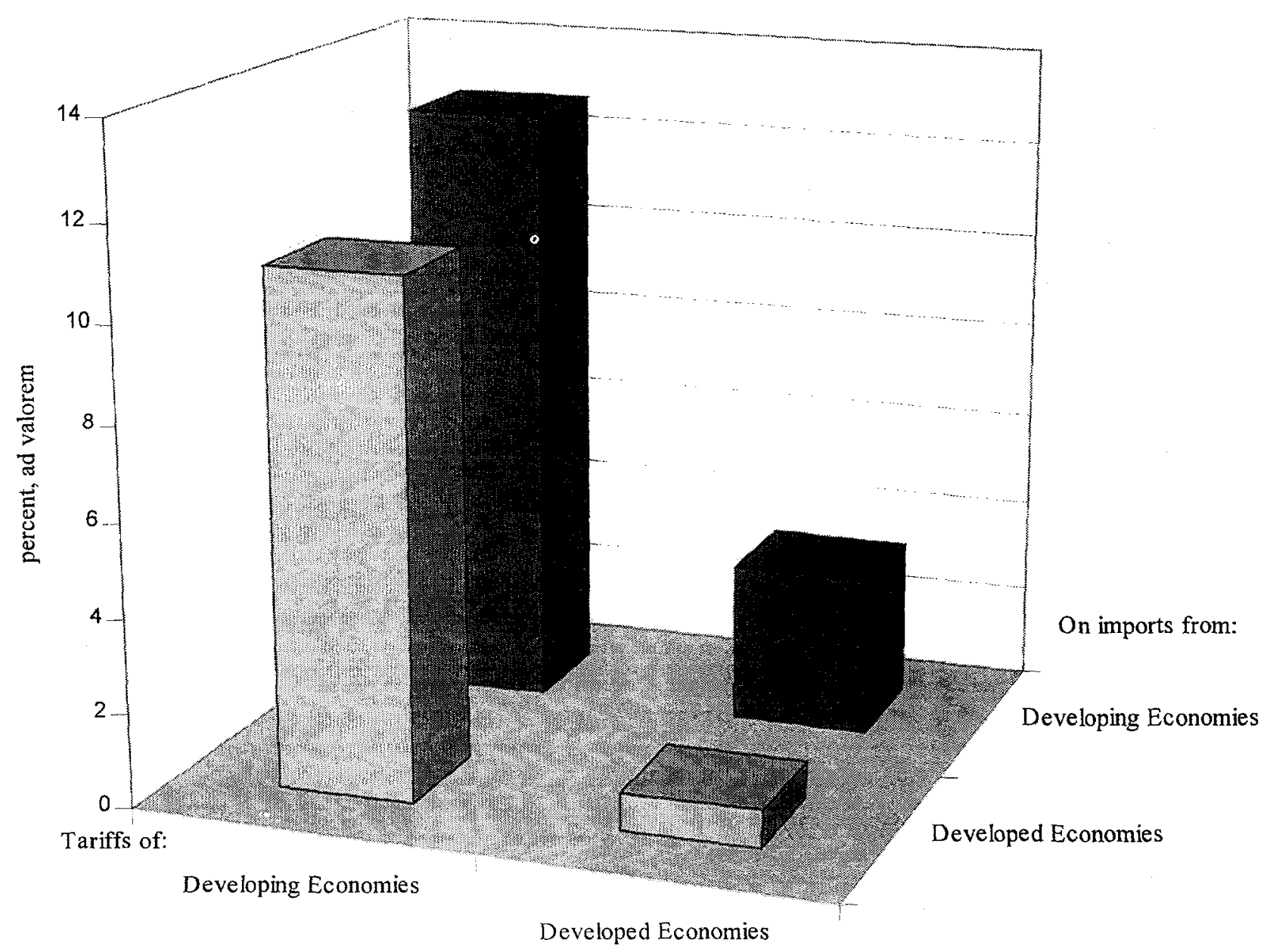




\section{QUANTITATIVE RESTRICTIONS}

The Uruguay Round re-emphasized GATT's concern to discipline the use of quantitative restrictions and similar instruments, and made considerable progress toward that end. Rules that allow such restrictions ${ }^{12}$ have been tightened, and those outside the new rules must be phased out. Grey-area measures such as voluntary export restraints are now illegal and existing measures must be phased out. In this section we will review notifications to the WTO of legal quantitative restrictions, and of those made illegal by the Uruguay Round Agreements and scheduled for elimination. In later sections we will review restrictions that have been imposed under various of the safeguard provisions in the Uruguay Round Agreements - some of which provisions allow for quantitative restrictions.

\section{GATT-LEGAL MEASURES}

Several GATT provisions that allow quantitative restrictions do not include notification requirements. Principal among these are Articles XX, General Exceptions, and XXI, Security Exceptions. Article XX covers, inter alia, restrictions to protect public morals (e.g., prohibition of importation of pornography) to apply technical or sanitary standards, to preserve human, animal and plant life, restrictions against imports produced by prison labor.

Some countries notify such restrictions, others do not. Table $Q R 1$ provides indicative information about the mix of legal quantitative restrictions that Members apply, but it does not provide reliable information about which Members apply legal quantitative restrictions. ${ }^{13}$ Virtually all countries have controls on some imports, e.g., of arms. The WTO Agreements do not require that Members report these restrictions and Table QR1 indicates that few Members have chosen to report them.

In Table QR1 we see that 49 times out of 57 (86 percent) Article XX or XXI was the justification cited for a quantitative restriction. The most frequently cited paragraph of Article $\mathrm{XX}$ is the one allowing restrictions to protect human, animal or plant live or health. Outside of Articles XX and XXI, Article XVIII.B, allowing developing countries to use quantitative restrictions to defend the balance of payments, is the most frequently cited Article. ${ }^{14}$

Though Articles XII and XVIII.B still provide for trade restrictions to defend the balanceof-payments, the Uruguay Round Understanding on Balance-of-Payments Provisions limited the scope for use of such. Even before that agreement, developing economies had been under considerable pressure to remove such restrictions, and use of the provision has declined. Only India, Nigeria, Tunisia, Bangladesh and Pakistan maintain restrictions under XVIII.B, and schedules for phasing out balance-of-payment based non-tariff-measures have already been

\footnotetext{
${ }^{12}$ The Agreements on Safeguards, on Agriculture and on Textiles and Clothing allow quantitative restrictions in certain circumstances. GATT 1994 under Article XI:2 allows quantitative export restrictions to deal with domestic shortages, also quantitative import restrictions for the application of standards and regulations, etc. Article XVII allows quantitative restrictions for the allocation of import licenses through state trading companies, Article XVIIIB for balance of payment reasons. Quantitative restrictions might also be justified under the general and security exceptions of Articles XX and XXI. For agricultural products, Article 4:2 of the Agriculture Agreement supercedes Article XI:2c of GATT 1994.

${ }^{13}$ GATT articles that allow restrictions have proven to be fungible in that almost any restriction can be at least arguably justified under several GATT provisions (Finger, in Martin and Winters, 1996). There will thus be a vague margin between restrictions that the GATT allows in principle and those it allows in fact.

${ }^{14}$ Notification of measures justified under Article XVIII.B is required.
} 
agreed with Tunisia and Pakistan. India's restrictions justified under XVIII.B are subject to a dispute settlement proceeding, and India has re-notified some of the measures under other GATT articles Nigeria's BOP-based quantitative restrictions have also been questioned.

\section{MEASURES NOTIFIED FOR POST-URUGUAY ROUND ELIMINATION}

The Uruguay Round Safeguards Agreement imposes time limits on all new safeguard measures. In concert it requires the phase-out of all existing safeguard measures now legal under GATT Article XIX. It also requires the elimination of all VERs and other restraints that would not be allowed under the Uruguay Round safeguard rules. ${ }^{15}$ Table QR2 lists all such measures notified by WTO Members. Only eight of the measures notified are measures taken under Article XIX that now come under sunset provisions. The brevity of this list, say, in comparison with the number of antidumping measures in place (below) reflects how infrequently Article XIX measures have been used to deal with troublesome imports. The other 18 measures listed are notified as inconsistent with the new Safeguard Agreement and subject to phase-out. Most of the measures (of both types) have been eliminated already, the remaining three are scheduled for elimination at the end of 1999.

The information in Table QR2 demonstrate that VERs have disappeared. To confirm that finding we looked for other information on VERs. A GATT tabulation (GATT 1992) identifying 79 such restraints outside agriculture and textiles/clothing that were in place as of 1992. Korea (46) and Japan (23) were most frequently involved on the exporters' side. On the importers' side, the European Union and the US accounted for 33 and 17 VERs each. Notifications since the Uruguay Round indicate that these arrangements are gone or will be gone on the deadline specified in the agreement. Among exporters, Japan submitted no report of continuing VERs, ${ }^{16}$ Korea's report indicates that all VERs with the US and the European Union have been eliminated. Thailand's notification indicates the same for the Thai VER on manioc to the European Union. Though the WTO does not require such notification, eighteen Members have notified the WTO that they maintain no quantitative restrictions. They are listed in a footnote to Table QR1.

WTO Trade Policy Reviews further support the conclusion that VERs have disappeared. The most recent TPR for Japan reports that all VERs in which Japan participated have been eliminated except the Japan-EU VER on cars - and that one will be gone by end 1999 (WTO, 1998). The 1996 Trade Policy Review for the US reports that the VERs agreed with other countries had been removed (WTO 1997). The accuracy of that finding is confirmed by the fact that it was not contested in discussion of the Trade Policy Reviews.

Despite this "elimination" of VERs, there are still WTO-legal ways for trade disputes to be resolved by exporters agreeing to restrain shipments. The antidumping and subsidies, countervailing measures agreements allow such "undertakings." Following the filing in 1998 of antidumping and countervailing duty cases by the US steel industry, the US reached agreement to a VER with non-WTO member Russia. As of March 1999 when this study was written, Brazil had proposed to curb exports voluntarily if a US antidumping case is suspended, and much pressure is being put on Japan to reduce exports to the US.

\footnotetext{
${ }^{15}$ Of course, the fungibility of GATT/WTO rules (footnote just above) means that a country wishing to maintain a grey area measure had several options for defending its legality.

${ }^{16}$ The EU notified the VER on Japanese exports of cars that the EU has notified under the phasing out provision of the Safeguard Agreement.
} 


\section{OVERALl Progress ON NTBS}

Tables QR3 and QR4 provide a view of recent reductions in the application of NTBs. The tabulations summarized in the tables cover export restraints, non-automatic licensing, variable charges and quantitative restrictions and price-quantity measures, but exclude antidumping and countervailing duties.

Among OECD countries, the principal finding is that the share of tariff lines affected by such measures declined significantly, or remained at a very low level (Australia and New Zealand) in all countries covered. In those two, the index remained constant. The decline in the NTB index for Norway is mainly due to the tariffication of a large number of agricultural tariff lines, the elimination of VERs is a key reason for the decline in NTBs in the US and the EU.

Information on developing economies' use of NTBs extracted from WTO Trade Policy Reviews suggests a significant reduction in use of NTBs. ${ }^{17}$ Colombia, Indonesia, Korea, Malaysia, Mexico, Morocco, South Africa and Thailand now take much less recourse to such trade restrictions. Among the developed economies listed in Table QR4 (which is based on TPRs) only one, Brazil, had a higher NTB index value in 1995-98 than 1989-94, and for Brazil the increase was small, less than 2 percentage points

WTO Trade Policy Reviews explicitly acknowledge the implementation of the Uruguay Round Agreements in bringing down NTBs in Mexico and Thailand by about 50 percent. In Colombia and Korea, the elimination of quantitative restrictions under the balance of payments provision has resulted in a major reduction of NTBs. The decline in the use of the balance of payments provision has been an important achievement in the post-UR period, although it was not explicitly part of the Uruguay Round package. ${ }^{18}$

\footnotetext{
${ }^{17}$ The OECD and the WTO-Trade Policy Reform tabulations are based on data at different levels of aggregation, hence we cannot compare the incidences of NTBs for developed economies (from the OECD tabulation) with those for developing economies (from the WTO-Trade Policy Reform tabulation.)

${ }^{18}$ Trade Policy Reviews for the other developing countries in Table QR4 did not look into the reasons for the decline of NTBs.
} 


\section{TABLE QR1: INDICATIVE LIST OF NOTIFICATIONS OF GATT-CONSISTENT* QUANTITATIVE RESTRICTIONS AND JUSTIFICATIONS, BY MEMBER}

\begin{tabular}{|c|c|c|c|c|c|}
\hline \multirow[b]{2}{*}{ Member } & \multicolumn{2}{|c|}{ GATT Articles or paragraphs cited } & \multirow[b]{2}{*}{ Product Categories } & \multirow[b]{2}{*}{$\begin{array}{l}\text { Type of } \\
\mathrm{QR}(* * *)\end{array}$} & \multirow[b]{2}{*}{$\begin{array}{l}\text { Year of last } \\
\text { Notification }\end{array}$} \\
\hline & Which ones $\left({ }^{* *}\right)$ & $\begin{array}{l}\text { Number: } \\
\text { Articles } \\
\text { XX, } \\
\text { XXI/Total }\end{array}$ & & & \\
\hline Argentina & & & Vehicles & $\bar{Q}$ & 1997 \\
\hline Australia & $\mathrm{XX}(\mathrm{b})$ & $1 / 1$ & Chemicals (Ozone depleting substances) & $P$ & 1996 \\
\hline Chile & $\mathrm{XX}(\mathrm{b})$ & $1 / 1$ & Used Vehicles & $\mathrm{P}$ & 1996 \\
\hline Cyprus & $\mathrm{XX}(\mathrm{b}),(\mathrm{d}), \mathrm{XXI}(\mathrm{a}),(\mathrm{b})$ & $4 / 4$ & Various Industrial Products & $\mathrm{L}$ & 1996 \\
\hline Fiji & $\mathrm{XX}, \mathrm{XXI}$ & $2 / 2$ & Drugs, Arms etc. (anything seditious) & $\bar{P}$ & 1997 \\
\hline Hong Kong & $\mathrm{XX}(\mathrm{b})$ & $1 / 1$ & Agricultural Chemicals (s.a) & $\overline{Q, P}$ & $1996-1998$ \\
\hline Hungary & & & $\begin{array}{l}\text { Food, Textiles, Wood, Jewelry, Motor } \\
\text { vehicles }\end{array}$ & $\overline{Q, L}$ & 1996 \\
\hline India & $\begin{array}{l}\text { XVII, XVII:B, } \\
\text { XX(b),(c),(d), XXI(b) }\end{array}$ & $4 / 6$ & $\begin{array}{l}\text { Food, Chemicals, Machinery, Wood, } \\
\text { Minerals, Metals, etc. }\end{array}$ & $\mathrm{L}, \mathrm{P}, \mathrm{O}$ & $1996-1997$ \\
\hline Jamaica & $\mathrm{XX}, \mathrm{XXI}$ & $2 / 2$ & Vehicles, Arms, Chemicals & $\mathbf{L}$ & 1998 \\
\hline Japan & \begin{tabular}{|l|}
$\mathrm{XI}: 2(\mathrm{c}), \mathrm{XX}(\mathrm{b}),(\mathrm{g})$ \\
$\mathrm{XXI}(\mathrm{b})(\mathrm{I})$
\end{tabular} & $4 / 5$ & $\begin{array}{l}\text { Food, Mineral Products, Chemicals, } \\
\text { Machinery, Arms }\end{array}$ & $\bar{Q}, \mathrm{O}$ & 1998 \\
\hline Korea & XVII, XVIII:B & $0 / 2$ & Food, Mineral Products, Textiles & $\mathrm{L}$ & 1997 \\
\hline Macau & 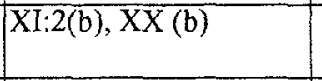 & $1 / 2$ & $\begin{array}{l}\text { Agricultural Products, Chemicals, Arms, } \\
\text { Machinery }\end{array}$ & $L, P$ & 1996 \\
\hline Malta & & & $\begin{array}{l}\text { Food, Chemicals, Minerals, Wood, } \\
\text { Metals, Vehicles, etc. }\end{array}$ & $\bar{L}$ & 1996 \\
\hline Morocco & $\mathrm{XX}(\mathrm{b}),(\mathrm{f}),(\mathrm{g}),(\mathrm{j}), \mathrm{XXI}$ & $5 / 5$ & Various & $\bar{L}$ & 1997 \\
\hline New Zealand & $\mathrm{XX}(\mathrm{b}),(\mathrm{g}),(\mathrm{j})$ & $3 / 3$ & Chemicals (Ozone depleting substances) & $\bar{P}$ & 1966 \\
\hline Pakistan & $\mathrm{XX}$ & $1 / 1$ & Food, Chemicals, Arms & $\bar{P}$ & 1997 \\
\hline Peru & $\mathrm{XX}(\mathrm{b}),(\mathrm{g})$ & $2 / 2$ & Used Textiles and Vehicles & $\mathrm{P}$ & 1996-1997 \\
\hline Philippines & XVIII:B & $0 / 1$ & $\begin{array}{l}\text { Agricultural Products, Oil, Arms. } \\
\text { Vehicles, Rubber Products, etc. }\end{array}$ & $\overline{\mathrm{L}, \mathrm{P}}$ & 1996 \\
\hline South Africa & \begin{tabular}{|l|} 
XX(a),(b),(c), \\
XXI:b(ii)
\end{tabular} & $4 / 4$ & $\begin{array}{l}\text { Agricultural Products, Oil, Arms, } \\
\text { Chemicals, Rubber, Metals, etc. }\end{array}$ & L & 1996 \\
\hline Turkey & $\begin{array}{l}\text { XI:2(a), } \\
\text { XX(a),(b),(c),(d),(f),(g) } \\
\text {,(h); XXI.(b)(i),(b)(ii) }\end{array}$ & $9 / 10$ & $\begin{array}{l}\text { Animals, Food, Chemicals, Textiles, } \\
\text { Arms }\end{array}$ & $\overline{Q, P}$ & $1996-1998$ \\
\hline Venezuela & XX(b),(g),(I) & $3 / 3$ & $\begin{array}{l}\text { Minerals, Chemicals, Rubber, Textiles, } \\
\text { Used Vehicles }\end{array}$ & $L, P$ & 1996 \\
\hline Zambia & $\mathrm{XX}(\mathrm{g}), \mathrm{XXI}$ & $2 / 2$ & Ivory, Wood, Metals & $\mathrm{P}, \mathrm{L}, \mathrm{O}$ & 1996 \\
\hline Totals & & $49 / 57$ & & & \\
\hline
\end{tabular}

Source: Notifications submitted by Member Countries to the Market Access Committee (*) Only GATT Articles

${ }^{* *}$ ) Four countries in addition to the three listed here maintaimed at the end of 1998 quantitative restrictions under the balance of payment provision (Article XVMII.B). They are Bangladesh, Nigeria (no conclusion of last consultation), Pakistan and Tunisia.

$\left({ }^{* * *}\right) \mathrm{P}=$ Prohibition, $\mathrm{Q}=\mathrm{Quota}, \mathrm{L}=$ Licensing, $\mathrm{O}=$ Other

P includes: Prohibition (P). Prohibition except under defined conditions (CP)

Q includes: Global quota (GQ), Global quota allocated by country (GQC), Bilateral quota (BQ)

$L$ includes: Automatic licensing (AL), Non-automatic licensing (NAL)

O includes: QR made effective through state trading (STR), Mixing regulation (MXR), Minimum Price (MPR) Voluntary Export Restraint (VER)

Note: Countries which notified that they do not maintain quantitative restrictions and year of notifications: Bahrain (1997), Bolivia (1997), Brunei Darussalam (1996), Costa Rica (1998) Dominican Republic (1996), Gambia (1997), Haiti (1998), Honduras (1997), Iceland (1996), Liechtenstein (1997), Mongolia (1998), Paraguay (1998), Singapore (1996), Switzerland (1997), Trinidad/Tabago (1996-1998), Uganda (1996), United Arab Emirates (1997), Uruguay (1996) 


\section{TABLE QR2: PRE-EXISTING MEASURES NOTIFIED BY MEMBERS AS SUBJECT TO ELIMINATION UNDER RULES ADOPTED AT THE URUGUAY ROUND}

(grey area measures and measures legal under Article XIX now subject to sunset provisions)

\begin{tabular}{|c|c|c|c|c|c|}
\hline $\begin{array}{l}\text { Importing } \\
\text { Member }\end{array}$ & $\begin{array}{l}\text { Restrained Exporters } \\
\text { (if available) }\end{array}$ & Product & Instrument & $\begin{array}{l}\text { Elimination } \\
\text { Date }\end{array}$ & $\begin{array}{l}\text { Sfg. Agm. } \\
\text { Article }\end{array}$ \\
\hline Cyprus & All countries & Most imports & $\begin{array}{l}\text { QRs, Prohibitions, } \\
\text { discretionary licensing }\end{array}$ & 31.12 .98 & 11 \\
\hline$\overline{\mathbf{E C}}$ & & Dried Grapes & $\begin{array}{l}\text { Minimum Import } \\
\text { Price }\end{array}$ & 31.12 .99 & 10 \\
\hline$\overline{\mathbf{E C}}$ & & Preserved Cherries & $\begin{array}{l}\text { Minimum Import } \\
\text { Price }\end{array}$ & 31.12 .99 & 10 \\
\hline$\overline{\mathrm{EC}}$ & Non-EC Countries & Live Bovine Animals & QR (Import License) & 01.07 .95 & 11 \\
\hline$\overline{\mathrm{EC}}$ & Non-EC Countries & $\begin{array}{l}\text { Swine and Meat of } \\
\text { Swine }\end{array}$ & QR (Import License) & 01.07 .95 & 11 \\
\hline$\overline{\mathrm{EC}}$ & Non-EC Countries & Rabbit Meat & $\overline{\mathrm{QR} \text { (Authorization) }}$ & 01.07 .95 & 11 \\
\hline$\overline{\mathrm{EC}}$ & All countries & Potatoes & QR (Certificates) & 01.11 .98 & 11 \\
\hline $\mathrm{EC}$ & $\begin{array}{l}\text { Non-EC Countries, except those with } \\
\text { a preferential agreement with the EC }\end{array}$ & Preserved Sardines & QR (Global Quota) & 31.12 .96 & 11 \\
\hline $\mathrm{EC}$ & $\begin{array}{l}\text { Non-EC Countries, except those with } \\
\text { a preferential agreement with the EC. }\end{array}$ & Preserved Tuna & QR (Global Quota) & 31.12 .96 & 11 \\
\hline$\overline{\mathrm{EC}}$ & Non-EC Countries & Lignite & $Q R$ & 31.12 .96 & 11 \\
\hline$\overline{\mathrm{EC}}$ & Non-EC Countries & Coal & QR (Áuthorization) & 31.12 .97 & 11 \\
\hline$\overline{\mathbf{E C}}$ & Japan & Motor Vehicles & VER & 31.12 .99 & 11 \\
\hline$\overline{\mathrm{EC}}$ & Korea & Microwave Ovens & VER & 02.06 .97 & 11 \\
\hline$\overline{\mathrm{EC}}$ & Korea & Color Picture Tubes & VER & 02.06 .97 & 11 \\
\hline$\overline{\mathrm{EC}}$ & Thailand & Manioc & VER & 30.06 .95 & 11 \\
\hline Japan & Korea & Chestnuts, shelled & VER & 31.12 .98 & 11 \\
\hline Korea & People's Rep. Of China & Hot Bean Paste & QR (Import License) & 31.12 .99 & 10 \\
\hline Nigeria & All countries & Wheat Flour & Import Prohibition & $\begin{array}{l}\text { no date } \\
\text { provided }\end{array}$ & 10 \\
\hline Nigeria & All countries & Sorghum & Import Prohibition & $\begin{array}{l}\text { no date } \\
\text { provided }\end{array}$ & 10 \\
\hline Nigeria & All countries & Millet & Import Prohibition & $\begin{array}{l}\text { no date } \\
\text { provided }\end{array}$ & 10 \\
\hline Nigeria & All countries & Gypsum & Import Prohibition & $\begin{array}{l}\text { no date } \\
\text { provided }\end{array}$ & 10 \\
\hline Nigeria & All countries & Kaolin & Import Prohibition & $\begin{array}{l}\text { no date } \\
\text { provided }\end{array}$ & 10 \\
\hline $\begin{array}{l}\text { South } \\
\text { Africa }\end{array}$ & All countries & $\begin{array}{l}\text { Oil and Oil Products, } \\
\text { Petroleum, Chemicals, } \\
\text { Rubber, Plastic }\end{array}$ & QR (Import licenses) & $\begin{array}{l}31.12 .98,31 . \\
12.96,31.07 . \\
96,28.02 .97\end{array}$ & 11 \\
\hline $\begin{array}{l}\text { UK, } \\
\text { Germany }\end{array}$ & Korea & $\begin{array}{l}\text { Stainless Steel Flat- } \\
\text { ware }\end{array}$ & VER & 31.12 .98 & 11 \\
\hline countries & Slovenia & $\begin{array}{l}\text { Wood in various forms, } \\
\text { Metal Waste and Scrap }\end{array}$ & $\begin{array}{l}\text { Special Export Tax, } \\
\text { rates } 10 \text { to } 25 \%\end{array}$ & $\begin{array}{l}01.01 .97 \text { and } \\
01.01 .98\end{array}$ & 11 \\
\hline $\begin{array}{l}\text { all WTO } \\
\text { Members }\end{array}$ & Korea & $\begin{array}{l}\text { Oysters in airtight } \\
\text { containers }\end{array}$ & VER & 31.12 .98 & 11 \\
\hline
\end{tabular}

Source: Notifications submitted by Member Countries to the WTO Committee on Safeguards

${ }^{2}$ Article 10, GATT XIX measures; Article 11, VERs and other measures inconsistent with the Safeguards Agr. 
TABle QR3: CORE Non TARIFF MEASURES* IN SElected OECD COUNTRIES

(Share of tariff lines with at least one NTB, in percentage)

\begin{tabular}{|l|c|c|}
\hline Country & 1993 & 1996 \\
\hline Australia & 0.3 & 0.3 \\
\hline Canada & 1.4 & 1.2 \\
\hline EU & 9.4 & 4.2 \\
\hline Iceland & 2.8 & 0.7 \\
\hline Japan & 3.8 & 2.6 \\
\hline Mexico & 2 & 1 \\
\hline New Zealand & 0 & 0 \\
\hline Norway & 24 & 3.8 \\
\hline Switzerland & 3.5 & 0.2 \\
\hline Turkey & 0.1 & 0.2 \\
\hline U.S. & 10.3 & 2.9 \\
\hline
\end{tabular}

Source: OECD 1997

* Core Non-Tariff Measures include: export restraints, non-automatic licensing, other quantitative restrictions, variable charges and other price control measures. The figures do not cover antidumping, countervailing duties and voluntary export/price restraints. 
TABLE QR4 CORE NON-TARIFF MEASURES IN SELECTED DEVELOPING ECONOMIES

\begin{tabular}{|l|c|}
\hline Economy & $\begin{array}{c}\text { Relative incidence of } \\
\text { NTBs } 1995-98^{\mathrm{b}}\end{array}$ \\
\hline Hong Kong & 0 \\
\hline Singapore & 1 \\
\hline Argentina & 2 \\
\hline Chile & 6 \\
\hline South Africa & 9 \\
\hline Colombia & 11 \\
\hline Mexico & 14 \\
\hline Morocco & 14 \\
\hline Thailand & 19 \\
\hline Malaysia & 21 \\
\hline Korea & 27 \\
\hline Indonesia & 33 \\
\hline Brazil & 48 \\
\hline India & 100 \\
\hline
\end{tabular}

Source: WTO Trade Policy Reviews

${ }^{a}$ Core Non-Tariff Measures include: export restraints, non-automatic licensing, other quantitative restrictions, variable charges, and other price control measures. The figures do not include coverage of antidumping, countervailing duties and voluntary export/price restraints.

${ }^{b}$ Relative NTB incidence where NTB incidence is measured by the share of 85 broad data categories with at least one NTB.

Revised April 22, 1999 


\section{TEXTILES AND CLOTHING}

Since the 1930s, developed economies have used negotiated or "voluntary" export restraints to limit their imports of textiles and clothing. ${ }^{19}$ Finally, in the Uruguay Round Agreements, the international community decided to put an end to this practice. The major provisions for eliminating quotas and VERs on textiles and clothing are as follows:

- all textiles and clothing products will be "integrated into GATT 1994" in four stages (1/1/1995, 1/1/1998, 1/1/2002,1/1/2005); encompassing 16 percent, 17 percent, 18 percent and 49 percent (by 1990 volume) of imports of all specified textiles and clothing products;

- import growth rates for all products not so integrated (i.e., that remain under restraint) will be increased in each of the three intervals between stages by 16 percent, 25 percent and 27 percent, respectively; ${ }^{20}$

- each of the four groups into which the spectrum of textile products has been divided (tops and yarns, fabrics, made up textile products, clothing) must be included in each of the integration.

The percentages listed in the first bullet above apply to "the total volume of the Member's 1990 imports of the products in the Annex."21 The annex runs to more than 30 pages of six-digit HS products and includes all textile and clothing products that were subject to MFA or MFA-type restraints in at least one importing country. ${ }^{22}$ Any one Member is unlikely to have restraints on all of the products on the list, and hence in the early stages will have the opportunity to "integrate" products on which it has no restrictions. As a matter of semantics then, the operative phrase in the agreement, to integrate into GATT 1994 is better described as "certifying that a product is clean of restrictions"

- A transitional safeguard measure may be applied by a Member ${ }^{24}$ to any product in the Annex, except for products already integrated into the GATT, i.e., liberalized as per the first bullet above.

Constraints for using the transitional safeguard mechanism are tighter than those for, say, the safeguards agreement - e.g., a transitional safeguard cannot extend beyond three years. Transitional safeguards may however be applied against specific exporters.

${ }^{19}$ Finger and Harrison (1996) provide a history of MFA-related restrictions on developed economies' imports of textiles and clothing, beginning with VERs by Japan in the 1930s.

${ }^{20}$ The percentages apply to growth rates, not to growth; e.g., if the agree quota growth rate is 3 percent, in the first interval this rate must increase to (1.16) 33 , equals 3.48 .

${ }^{21}$ Agreement on Textiles and Clothing, Article 2, paragraph 6.

22 WTO Secretariat 1999 , p. 66.

23 Those that would be illegal under GATT 1994.

24 This includes Members who did not have in place restrictions under the MFA, but who notified the Textiles Monitoring Board that they retained the right to use the transitional safeguards provision. Sixty-four Members so notified. Nine Members notified that they did not wish to retain the right to use transitional safeguards.(WTO G/L/179, p. 14.) 


\section{IMPLEMENTATION - CONCENTRATED ON RELATIVELY UNRESTRICTED PRODUCTS}

The developed economies' policies toward these imports are among their most restrictive. Hufbauer and Elliott estimate, for example, that almost $9 / 10$ of the cost to the US economy of US import restrictions are accounted for by restrictions on imports of textiles and clothing. At the same time, textiles and clothing account for more than 20 percent of developing economies' industrial exports, hence there is much to gain all around from liberalization.

Implementation has proceeded through the first two stages; thus, each importing country has integrated into GATT 1994 products accounting for at least 33 percent of its imports. There have been, however, loud complaints that minimal liberalization has resulted from this implementation. The most often voiced complaints are that each importing Member has weighted its liberalization toward products:

- that were not under restraint in that country,

- with little value added or on which developed economies do not have comparative advantage, e.g., yarns and fabrics rather than clothing,

- with high tariffs,

- and that they have overused transitional safeguards or have applied antidumping and other WTO-legal restrictions disproportionally against textiles and clothing.

We will review below available evidence on each of these.

The tabulation in Table $\mathrm{TC} 1$ - taken from information notified to the Textiles Monitoring Board - does indicate that importers have selected items that were not under restriction. Norway, of the countries in the table, is the exception. Norway has decided to liberalize more rapidly than the agreement requires. ${ }^{25}$

For the US and Canada (combined) textile imports and clothing imports are about equal, for Western European countries (combined) clothing imports are considerably larger than textile imports. ${ }^{26}$ Even so, clothing has made up a small part of the products the countries listed in Table TC2 which have been integrated into GATT 1994 - among the best of them, hardly more than 10 percent.

\section{TARIFF CUTS AND REMAINING TARIFFS}

Tariffs on textiles and clothing remain high relative to those on industrial products generally (Table TC3). Table TC3 also reports that the Uruguay Round tariff cuts on textiles and clothing were relatively large. Not only were the cuts (measured by $\mathrm{dT} /(1+\mathrm{T})$ deeper on textiles and clothing, they were applied to a larger fraction of imports.

\section{TRANSITIONAL SAFEGUARDS}

Table TC4 lists all transitional safeguard measures implemented from implementation of the Uruguay Round Agreements through March 19, 1999. Soon after the agreement went into force, the United States applied a number of transitional safeguards, all but one of which had been lifted by March 1999. The US has not imposed a transitional safeguard since March 1996. Brazil's actions, all imposed in January 1996, are mostly still in place. The only other country to

\footnotetext{
${ }^{25}$ WTO document G/C/M/23, p. 23.

${ }^{26}$ WTO, Annual Report 1997, Tables IV.53 and IV.60.
} 
apply a transitional safeguard measure was Colombia, but the two measures applied by Colombia in 1998 have both been rescinded.

\section{ANTIDUMPING}

Table AD6 reports recent antidumping initiations by sector. From these dates it appears that the EU has initiated a significant number of cases against textile and clothing imports. These cases however were not on products that the EU liberalized in the first two rounds of phasing textile and clothing tariff lines into the GATT 1994. 


\section{TABLE TC1: NUMBERS OF MFA QUOTA LIMITS NOTIFIED AND ELIMINATEd IN STAGES 1 AND 2}

(Stage 1 plus stage 2 requires integration of $33 \%$, by import volume.)

\begin{tabular}{|l|c|c|c|}
\hline \multirow{2}{*}{ Member } & Notified, & \multicolumn{2}{|c|}{ Eliminated } \\
\cline { 3 - 4 } & Number & Number & Percentage \\
\hline United States & 650 & 8 & 1 \\
\hline European Union & 199 & 14 & 7 \\
\hline Canada & 205 & 28 & 14 \\
\hline Norway & 54 & 46 & 85 \\
\hline
\end{tabular}

Source: WTO Doc. G/L/179, page 29. Norway G/C/M/23, p.23.

TABle TC2: Clothing as a PerCentage By Volume of Products INTEgRated IN STAGES 1 AND 2

\begin{tabular}{|l|c|}
\hline Member & Percentage \\
\hline United States & 12.4 \\
\hline European Union & 7.2 \\
\hline Canada & 7.9 \\
\hline Norway & 10.6 \\
\hline
\end{tabular}

Source: WTO Doc. G/L/179, page 29. 
TABle TC3: POST URUguay Round APPlied TARIFF RATES AND URUGUAY Round TARIFF CUTS ON TEXTILES AND CLOTHING AND ON ALL INDUSTRIAL GOODS

\begin{tabular}{|c|c|c|c|c|c|c|}
\hline & \multicolumn{2}{|c|}{ post-UR applied rate } & \multicolumn{2}{|c|}{$\begin{array}{c}\text { UR cut } \\
\mathrm{dT} /(1+\mathrm{T})^{*} 100\end{array}$} & \multicolumn{2}{|c|}{$\begin{array}{c}\text { Percentage of imports } \\
\text { subject to cut }\end{array}$} \\
\hline & $\begin{array}{l}\text { Textiles } \\
\text { And } \\
\text { Clothing }\end{array}$ & $\begin{array}{l}\text { Industrial } \\
\text { goods }\end{array}$ & $\begin{array}{l}\text { Textiles } \\
\text { and } \\
\text { clothing }\end{array}$ & $\begin{array}{l}\text { Industrial } \\
\text { goods }\end{array}$ & $\begin{array}{l}\text { Textiles } \\
\text { and } \\
\text { clothing }\end{array}$ & $\begin{array}{l}\text { Industrial } \\
\text { goods }\end{array}$ \\
\hline \multicolumn{7}{|c|}{ Selected developed economies } \\
\hline Australia & 22.6 & 9.7 & 9.0 & 3.8 & 54.1 & 46.2 \\
\hline Canada & 14.2 & 2.6 & 3.7 & 1.1 & 64.8 & 22.5 \\
\hline European Union & 8.7 & 2.9 & 1.4 & 1.3 & 70.5 & 43.3 \\
\hline Japan & 7.2 & 1.4 & 1.9 & 1.1 & 83.5 & 42.1 \\
\hline United States & 14.8 & 3.1 & 1.7 & 1.2 & 86 & 42.5 \\
\hline \multicolumn{7}{|c|}{ Selected developing economies } \\
\hline Brazil & 15.5 & 11.8 & 0.0 & 0.0 & 0.0 & 0.1 \\
\hline Colombia & 15.9 & 10.4 & 0.0 & 0.0 & 0.0 & 0.6 \\
\hline $\begin{array}{l}\text { Czech \& Slovak } \\
\text { Customs Union }\end{array}$ & 6.6 & 3.7 & 1.7 & 0.9 & 72.8 & 72.8 \\
\hline India & 42.4 & 29 & 7.4 & 6.8 & 41.1 & 41.1 \\
\hline Korea & 13 & 7.6 & 5.1 & 6.2 & 71.1 & 71.1 \\
\hline Thailand & 28.9 & 26.8 & 19.6 & 5.4 & 41.4 & 41.4 \\
\hline Turkey & 44.2 & 24.2 & 10.5 & 2.6 & 41.7 & 41.7 \\
\hline Zimbabwe & 17.6 & 4.5 & 1.3 & 0.1 & 2 & 2 \\
\hline $\begin{array}{l}\text { All developed } \\
\text { economies in the IDB }\end{array}$ & 8.4 & 2.5 & 1.4 & 1.0 & 53.0 & 32.3 \\
\hline $\begin{array}{l}\text { All developing } \\
\text { economies in the IDB }\end{array}$ & 21.2 & 13.3 & 4.1 & 2.7 & 48.6 & 33.4 \\
\hline $\begin{array}{l}\text { All economies in the } \\
\text { IDB }\end{array}$ & 9.8 & 4.2 & 1.6 & 1.3 & 52.6 & 32.4 \\
\hline
\end{tabular}

Note:

${ }^{a}$ Averaged over all textiles and clothing tariff lines, including those with zero cuts. 
TABLE TC4: TRANSITIONAL SAFEgUARDS IN TEXTILES AND Clothing SINCE 1/95

\begin{tabular}{|c|c|c|c|c|c|c|c|}
\hline $\begin{array}{l}\text { Member } \\
\text { requesting } \\
\text { consultations }\end{array}$ & $\begin{array}{l}\text { Member } \\
\text { subject to } \\
\text { request for } \\
\text { consultation }\end{array}$ & Product & $\begin{array}{c}\text { Measure } \\
\text { introduced } \\
\text { on }\end{array}$ & $\begin{array}{l}\text { Type of } \\
\text { safeguard } \\
\text { measure } \\
\text { introduced }\end{array}$ & $\begin{array}{l}\text { Review by } \\
\text { the TMB }\end{array}$ & $\begin{array}{l}\text { Follow-up of } \\
\text { the TMB } \\
\text { review }\end{array}$ & $\begin{array}{c}\text { measure still in } \\
\text { force (on } \\
19.03 .1999)\end{array}$ \\
\hline United States & El Salvador & $\begin{array}{l}\text { Cotton \& man-made } \\
\text { fiber pajamas \& other } \\
\text { nightwear }\end{array}$ & 27.03 .95 & $\begin{array}{l}\text { Agreed } \\
\text { restraint }\end{array}$ & \multicolumn{2}{|c|}{ United States rescinded } & no \\
\hline United States & Honduras & $\begin{array}{l}\text { Cotton \& man-made } \\
\text { fiber pajamas \& other } \\
\text { nightwear }\end{array}$ & 27.03 .95 & $\begin{array}{l}\text { Unilateral } \\
\text { restraint }\end{array}$ & Yes & $\begin{array}{l}\text { United States } \\
\text { rescinded }\end{array}$ & no \\
\hline United States & Jamaica & $\begin{array}{l}\text { Cotton \& man-made } \\
\text { fiber pajamas \& other } \\
\text { nightwear }\end{array}$ & 27.03 .95 & $\begin{array}{l}\text { Agreed } \\
\text { restraint }\end{array}$ & \multicolumn{2}{|c|}{ United States rescinded } & no \\
\hline United States & Costa Rica & $\begin{array}{l}\text { Cotton \& man-made } \\
\text { fiber underwear }\end{array}$ & 27.03 .95 & $\begin{array}{l}\text { Unilateral } \\
\text { restraint }\end{array}$ & Yes & $\begin{array}{l}\text { Dispute } \\
\text { settlement } \\
\text { panel }\end{array}$ & no \\
\hline United States & $\begin{array}{l}\text { Dominican } \\
\text { Republic }\end{array}$ & $\begin{array}{l}\text { Cotton \& man-made } \\
\text { fiber underwear }\end{array}$ & 27.03 .95 & $\begin{array}{l}\text { Agreed } \\
\text { restraint }\end{array}$ & Yes & & no \\
\hline United States & El Salvador & $\begin{array}{l}\text { Cotton \& man-made } \\
\text { fiber underwear }\end{array}$ & 27.03 .95 & $\begin{array}{l}\text { Agreed } \\
\text { restraint }\end{array}$ & Yes & & no \\
\hline
\end{tabular}


Table TC4: Transitional Safeguards...(continued)

\begin{tabular}{|c|c|c|c|c|c|c|c|}
\hline $\begin{array}{l}\text { Member } \\
\text { requesting } \\
\text { consultations }\end{array}$ & $\begin{array}{l}\text { Member } \\
\text { subject to } \\
\text { request for } \\
\text { consultation }\end{array}$ & Product & $\begin{array}{c}\text { Measure } \\
\text { introduced } \\
\text { on }\end{array}$ & $\begin{array}{l}\text { Type of } \\
\text { safeguard } \\
\text { measure } \\
\text { introduced } \\
\end{array}$ & $\begin{array}{l}\text { Review by } \\
\text { the TMB }\end{array}$ & $\begin{array}{l}\text { Follow-up of } \\
\text { the TMB } \\
\text { review }\end{array}$ & $\begin{array}{c}\text { measure still in } \\
\text { force (on } \\
19.03 .1999)\end{array}$ \\
\hline United States & Honduras & $\begin{array}{l}\text { Cotton \& man-made } \\
\text { fiber underwear }\end{array}$ & 27.03 .95 & $\begin{array}{l}\text { Unilateral } \\
\text { restraint }\end{array}$ & Yes & $\begin{array}{l}\text { Subsequent } \\
\text { agreed } \\
\text { restraint, } \\
\text { reviewed }\end{array}$ & no \\
\hline United States & Turkey & $\begin{array}{l}\text { Cotton \& man-made } \\
\text { fiber underwear }\end{array}$ & 28.03 .95 & $\begin{array}{l}\text { Unilateral } \\
\text { restraint }\end{array}$ & $\begin{array}{l}\text { Agreed } \\
\text { restraint } \\
\text { during } \\
\text { Review by } \\
\text { the } \\
\end{array}$ & $\begin{array}{l}\text { Agreed } \\
\text { restraint } \\
\text { reviewed }\end{array}$ & no \\
\hline United States & Colombia & $\begin{array}{l}\text { Cotton \& man-made } \\
\text { fiber underwear }\end{array}$ & 29.03 .95 & $\begin{array}{l}\text { Agreed } \\
\text { restraint }\end{array}$ & Yes & & no \\
\hline United States & Thailand & $\begin{array}{l}\text { Cotton \& man-made } \\
\text { fiber underwear }\end{array}$ & 29.03 .95 & $\begin{array}{l}\text { Unilateral } \\
\text { restraint }\end{array}$ & \multicolumn{2}{|c|}{$\begin{array}{l}\text { United States rescinded } \\
\text { during review }\end{array}$} & no \\
\hline United States & India & $\begin{array}{l}\text { Woven wool shirts and } \\
\text { blouses }\end{array}$ & 18.04 .95 & $\begin{array}{l}\text { Unilateral } \\
\text { restraint }\end{array}$ & Yes & \begin{tabular}{|l} 
Dispute \\
settlement \\
panel
\end{tabular} & no \\
\hline United States & India & $\begin{array}{l}\text { Women's and girl's wool } \\
\text { coats }\end{array}$ & 18.04 .95 & $\begin{array}{l}\text { Unilateral } \\
\text { restraint }\end{array}$ & \multicolumn{2}{|c|}{$\begin{array}{l}\text { Yes } \\
\text { Dispute settlement panel } \\
\text { requested, US rescinded. } \\
\text { India requested } \\
\text { termination of further } \\
\text { action in pursuance of } \\
\text { decision to establish a } \\
\text { panel }\end{array}$} & no \\
\hline
\end{tabular}




\begin{tabular}{|c|c|c|c|c|c|c|c|}
\hline $\begin{array}{l}\text { Member } \\
\text { requesting } \\
\text { consultations }\end{array}$ & $\begin{array}{l}\text { Member } \\
\text { subject to } \\
\text { request for } \\
\text { consultation }\end{array}$ & Product & $\begin{array}{c}\text { Measure } \\
\text { introduced } \\
\text { on }\end{array}$ & $\begin{array}{l}\text { Type of } \\
\text { safeguard } \\
\text { measure } \\
\text { introduced }\end{array}$ & $\begin{array}{l}\text { Review by } \\
\text { the TMB }\end{array}$ & $\begin{array}{l}\text { Follow-up of } \\
\text { the TMB } \\
\text { review }\end{array}$ & $\begin{array}{c}\text { measure still in } \\
\text { force (on } \\
19.03 .1999)\end{array}$ \\
\hline United States & India & $\begin{array}{l}\text { Men's \& boys' wool } \\
\text { coats other than suit-type }\end{array}$ & 18.04 .95 & $\begin{array}{l}\text { Unilateral } \\
\text { restraint }\end{array}$ & Yes & $\begin{array}{l}\text { United States } \\
\text { rescinded }\end{array}$ & no \\
\hline United States & Honduras & $\begin{array}{l}\text { Women's and girls' wool } \\
\text { coats }\end{array}$ & 24.04 .95 & $\begin{array}{l}\text { Unilateral } \\
\text { restraint }\end{array}$ & \multicolumn{2}{|c|}{$\begin{array}{l}\text { Agreed restraint during } \\
\text { review }\end{array}$} & no \\
\hline United States & Philippines & Man-made fiber luggage & 24.04 .95 & $\begin{array}{l}\text { Unilateral } \\
\text { restraint }\end{array}$ & \multicolumn{2}{|c|}{ Rescinded before review } & no \\
\hline United States & Brazil & $\begin{array}{l}\text { Men's \& boys' wool } \\
\text { coats other than suit-type }\end{array}$ & 26.04 .95 & None & & & no \\
\hline United States & Hong Kong & $\begin{array}{l}\text { Woven wool shirts and } \\
\text { blouses }\end{array}$ & 27.04 .95 & $\begin{array}{l}\text { Unilateral } \\
\text { restraint }\end{array}$ & Yes & $\begin{array}{l}\text { United States } \\
\text { rescinded }\end{array}$ & no \\
\hline United States & Sri Lanka & Man-made fiber luggage & 27.04 .95 & $\begin{array}{l}\text { Agreed } \\
\text { restraint }\end{array}$ & \multicolumn{2}{|c|}{ United States rescinded } & no \\
\hline United States & Thailand & Man-made fiber luggage & 28.04 .95 & $\begin{array}{l}\text { Unilateral } \\
\text { restraint }\end{array}$ & \multicolumn{2}{|c|}{ Rescinded before review } & no \\
\hline United States & Thailand & Artificial staple yarn & 28.04 .95 & $\begin{array}{l}\text { Unilateral } \\
\text { restraint }\end{array}$ & \multicolumn{2}{|c|}{ Agreed restraint reviewed } & no \\
\hline United States & Guatemala & $\begin{array}{l}\text { Cotton and man-made } \\
\text { fiber skirts }\end{array}$ & 31.05 .95 & $\begin{array}{l}\text { Agreed } \\
\text { restraint }\end{array}$ & \multicolumn{2}{|c|}{ Agreed restraint reviewed } & no \\
\hline United States & Colombia & $\begin{array}{l}\text { Women's and girls' wool } \\
\text { suits }\end{array}$ & 31.05 .95 & $\begin{array}{l}\text { Agreed } \\
\text { restraint }\end{array}$ & \multicolumn{2}{|c|}{ Agreed restraint reviewed } & no \\
\hline
\end{tabular}




\begin{tabular}{|c|c|c|c|c|c|c|c|}
\hline $\begin{array}{l}\text { Member } \\
\text { requesting } \\
\text { consultations }\end{array}$ & $\begin{array}{l}\text { Member } \\
\text { subject to } \\
\text { request for } \\
\text { consultation } \\
\end{array}$ & Product & $\begin{array}{c}\text { Measure } \\
\text { introduced } \\
\text { on }\end{array}$ & $\begin{array}{l}\text { Type of } \\
\text { safeguard } \\
\text { measure } \\
\text { introduced }\end{array}$ & $\begin{array}{l}\text { Review by } \\
\text { the TMB }\end{array}$ & $\begin{array}{l}\text { Follow-up of } \\
\text { the TMB } \\
\text { review }\end{array}$ & $\begin{array}{c}\text { measure still in } \\
\text { force (on } \\
19.03 .1999)\end{array}$ \\
\hline United States & Philippines & $\begin{array}{l}\text { Women's and girls' wool } \\
\text { suits }\end{array}$ & 31.05 .95 & $\begin{array}{l}\text { Unilateral } \\
\text { restraint }\end{array}$ & \multicolumn{2}{|c|}{ Rescinded before review } & no \\
\hline United States & Costa Rica & $\begin{array}{l}\text { Cotton \& man-made } \\
\text { fiber pajamas \& other } \\
\text { nightwear }\end{array}$ & 29.06 .95 & $\begin{array}{l}\text { Unilateral } \\
\text { restraint }\end{array}$ & \multicolumn{2}{|c|}{ Rescinded before review } & no \\
\hline United States & El Salvador & $\begin{array}{l}\text { Cotton \& man-made } \\
\text { fiber skirts }\end{array}$ & 29.03 .96 & $\begin{array}{l}\text { Unilateral } \\
\text { restraint }\end{array}$ & \multicolumn{2}{|c|}{$\begin{array}{l}\text { Agreed restraint before } \\
\text { review }\end{array}$} & yes \\
\hline United States & Pakistan & $\begin{array}{l}\text { Yarn for sale, } 85 \% \text { or } \\
\text { more by weight cotton } \\
\text { ring spun }\end{array}$ & $\begin{array}{c}\text { not } \\
\text { introduced }\end{array}$ & & & & no \\
\hline Brazil & Hong Kong & $\begin{array}{l}\text { Woven artificial filament } \\
\text { fabric }\end{array}$ & 01.06 .96 & $\begin{array}{l}\text { Unilateral } \\
\text { restraint }\end{array}$ & Yes & $\begin{array}{l}\text { Brazil } \\
\text { rescinded }\end{array}$ & no \\
\hline Brazil & Hong Kong & $\begin{array}{l}\text { M\&B shirts, knitted or } \\
\text { crocheted, of other } \\
\text { textile material }\end{array}$ & 01.06 .96 & $\begin{array}{l}\text { Unilateral } \\
\text { restraint }\end{array}$ & Yes & $\begin{array}{l}\text { Brazil } \\
\text { rescinded }\end{array}$ & no \\
\hline Brazil & Korea & $\begin{array}{l}\text { Woven fabric containing } \\
85 \% \text { or more by weight } \\
\text { artificial staple }\end{array}$ & 01.06 .96 & $\begin{array}{l}\text { Unilateral } \\
\text { restraint }\end{array}$ & \multicolumn{2}{|c|}{$\begin{array}{l}\text { Agreed restraint before } \\
\text { deferred review }\end{array}$} & yes \\
\hline Brazil & Korea & $\begin{array}{l}\text { Woven artificial filament } \\
\text { fabric }\end{array}$ & 01.06 .96 & $\begin{array}{l}\text { Unilateral } \\
\text { restraint }\end{array}$ & \multicolumn{2}{|c|}{$\begin{array}{l}\text { Agreed restraint before } \\
\text { deferred review }\end{array}$} & yes \\
\hline Brazil & Korea & Polyester filament fabric & 01.06 .96 & $\begin{array}{l}\text { Unilateral } \\
\text { restraint }\end{array}$ & \multicolumn{2}{|c|}{$\begin{array}{l}\text { Agreed restraint before } \\
\text { deferred review }\end{array}$} & yes \\
\hline
\end{tabular}


Table TC4: Transitional Safeguards...(continued)

\begin{tabular}{|l|l|l|l|l|l|l|l|}
\hline $\begin{array}{l}\text { Member } \\
\text { requesting } \\
\text { consultations }\end{array}$ & $\begin{array}{l}\text { Member } \\
\text { subject to } \\
\text { request for } \\
\text { consultation }\end{array}$ & Product & $\begin{array}{l}\text { Measure } \\
\text { introduced } \\
\text { on }\end{array}$ & $\begin{array}{l}\text { Type of } \\
\text { safeguard } \\
\text { measure } \\
\text { introduced }\end{array}$ & $\begin{array}{l}\text { Follow-up of } \\
\text { Review by } \\
\text { the TMB }\end{array}$ & $\begin{array}{l}\text { measure still in } \\
\text { ThB } \\
\text { force (on } \\
\text { 19.03.1999) }\end{array}$ \\
\hline Brazil & Korea & $\begin{array}{l}\text { Other synthetic filament } \\
\text { fabric }\end{array}$ & 01.06 .96 & $\begin{array}{l}\text { Unilateral } \\
\text { restraint }\end{array}$ & $\begin{array}{l}\text { Agreed restraint before } \\
\text { deferred review }\end{array}$ & yes \\
\hline Brazil & Korea & $\begin{array}{l}\text { Sheeting of staple } \\
\text { filament fiber } \\
\text { combinations }\end{array}$ & 01.06 .96 & $\begin{array}{l}\text { Unilateral } \\
\text { restraint }\end{array}$ & $\begin{array}{l}\text { Agreed restraint before } \\
\text { deferred review }\end{array}$ & yes \\
\hline Colombia & Brazil & Denim & 17.07 .98 & $\begin{array}{l}\text { Unilateral } \\
\text { restraint }\end{array}$ & Yes & $\begin{array}{l}\text { Colombia } \\
\text { rescinded }\end{array}$ & no \\
\hline Colombia & India & Denim & 17.07 .98 & $\begin{array}{l}\text { Unilateral } \\
\text { restraint }\end{array}$ & Yes & $\begin{array}{l}\text { Colombia } \\
\text { rescinded }\end{array}$ & no \\
\hline
\end{tabular}

Source: Reports of the Textiles Monitoring Body of the WTO 


\section{AGRICULTURE}

The agriculture negotiations focused on three categories of policy; import restrictions, domestic support programs, and export subsidy programs. We will pay attention principally to import restrictions.

\section{THE INTENT OF THE NEGOTIATORS}

On import restrictions, the major objective of the agreement is to establish a "tariffs only" regime - to eliminate all forms of import restriction other than bound tariff rates. To do so, all members were required to "tariffy" their non-tariff import restrictions. This conversion was based on the price gap methodology, with the methodological details being set out in technical guidelines on how to measure the gap between the domestic price (the price inside the protection wall) and the world price. ${ }^{27}$ The base period for the conversion, members agreed, would be 1986-1988, a period when many agricultural prices had been unusually low. Because agricultural policies try to maintain a relatively stable - and high - domestic price, the price gap calculated from this base period coupled, in some cases, with other adjustments allowed by the technical guidelines, frequently resulted in high tariff rates. Developing countries had the option to submit ceiling rates on previously unbound tariff items, with the additional proviso to remove all agriculture-specific non-tariff measures. Each member's legal obligation is defined by its schedule of tariff rates annexed to the GATT $1994 .^{28}$

According to the WTO Secretariat, forty countries participated in the tariffication process which covered (in aggregate) about 22 percent of their tariff lines. ${ }^{29}$ Finger-Ingco-Reincke calculations over the IDB show that tariffication covered, by value, just over one-third of tariffying countries' agriculture imports.

The modalities document also gave targets for tariff reductions. A developed country member was to reduce its duties, including those resulting from tariffication, across all agricultural tariff lines by a simple average of 36 percent over six years, with a minimum reduction of 15 percent on individual products. A developing country member was to reduce its duties by 24 percent over 10 years, and least developed countries were not required to make reductions. $^{30}$

\footnotetext{
${ }^{27}$ Following their use to establish the draft schedules of concessions and commitments, the technical guidelines were re-issued as Uruguay Round document MTM.GNG/MA/W/24, Modalities For The Establishment of Specific Binding Commitments Under The Reform Program, December 20, 1993.

${ }^{28}$ The reader should be careful to recognize the difference between the negotiating process through which legal commitments are agreed and the legal commitments themselves. The conversion guidelines were part of the negotiating process. They likely influenced what tariff rates one Member was willing to accept from another, but once a Member's schedule of rates was accepted and annexed to GATT 1994, the conversions guidelines became irrelevant. No Member can be taken to the dispute settlement mechanism on its bound rates being higher than those calculated with the formulas of the conversion guidelines.

${ }^{29}$ WTO Secretariat (1999), p. 136.

${ }^{30}$ Again the schedules of commitments, not the formula, define legal obligations.
} 


\section{Tariff quota commitments}

As part of the tariffication package, WTO Members agreed to maintain, for tariffied products, "current" import access opportunities at levels corresponding to those existing during the 1986-88 base period at terms not less favorable than in that period. Where such current access had been less than 5 per cent of domestic consumption of the product in question in the base period, the agreement required an (additional) minimum access opportunity on a mostfavored nation basis ${ }^{31}$ at a low tariff rate. This was to ensure that in 1995 , current and minimum access opportunities combined represented at least 3 per cent of base-period consumption and are progressively expanded to reach 5 per cent of that consumption in the year 2000 (developed countries) or 2004 (developing countries), respectively. ${ }^{32}$

\section{ESTIMATING HOW THE AGREEMENT HAS CHANGED MARKET ACCESS}

Implementing the tariff part of the agreement involves the following steps:

- As explained above, Convert to tariffs-only, i.e., determine new tariff rates for all tariff lines with NTBs, eliminate the NTBs. (Many of the new rates are specific rates, not ad valorem rates.)

- Bind all tariff lines - those on which NTBs have been converted to tariffs and those, on which there were tariffs only, i.e., no NTBs.

- Reduce the bound rates.

legal commitments are those specified in the schedules of rates attached by Members, possibly higher - even including staged reductions - than the tariff equivalent of initial measures. The Finger-Ingco-Reincke calculations that we report here are based on work by Ingco (1995) that used 1986-1988 as the base period for calculating (a) the ad valorem equivalents of overall protection applied in that period, and (b) the ad valorem equivalents of the tariffied bound rates.

Ingco found that many of the new bound rates were above the rates actually applied in the base period, and that some of the post-Uruguay Round bound rates - the rates that incorporate all of the scheduled reductions - are above the tariff equivalents of all protection applied before the Uruguay Round. While the focus of the Finger-Ingco-Reincke calculations we report here is on isolating the instances in which the Uruguay Round schedules do imply a reduction of protection, we will pay attention to her evidence on this "dirty tariffication."

Suppose for example, that the ad valorem equivalent rates for a particular tariffied line, as of the base period, were as follows:

$\begin{array}{ll}\begin{array}{l}\text { Base period applied protection } \\ \text { (including the tariff equivalent of NTBs) }\end{array} & 20 \% \\ \text { Immediate post UR bound rate } & 30 \% \\ \begin{array}{l}\text { Final post UR bound rate that } \\ \text { incorporates the scheduled reductions }\end{array} & 18 \%\end{array}$

\footnotetext{
${ }^{31}$ Importers can however count special arrangements as part of their minimum access commitments and can allocate their minimum access to exporters that have special arrangements. Thus sugar, beef etc., imports of the US and the European Union will be allocated as before. (Hathaway and Ingco, 1996, p. 48).

${ }^{32}$ Again, legal commitments are defined by the schedules, which specify at which quantities the higher tariff rate will go into effect.
} 
In this instance, the Finger-Ingco-Reincke calculations would take as the "before-UR" rate the $20 \%$ applied rate, not the $30 \%$ bound rate. Only if the final-UR bound rate is below the "before-UR" applied rate does the country's Uruguay Round commitment imply a tariff reduction. Thus the "after-UR" rate in the Finger-Ingco-Reincke calculations is the lower of the "before-UR" rate or the post-UR bound rate.

The guideline of a 36 percent reduction is met in this example - the reduction of the bound rate from $30 \%$ to $18 \%$ is more than a 36 percent reduction. The Finger-Ingco-Reincke calculations, however, look at how the Uruguay Round has reduced applied protection, and would include only the reduction from the previously applied rate, i.e., from $20 \%$, to $18 \%$. If the final-UR bound rate were at or above the base period applied rate - in this example, at or above $20 \%$, the Finger-Ingco-Reincke calculations would attribute zero reduction to the Uruguay Round. $^{33}$

\section{RESULTS: TARIFF BINDINGS AND REDUCTIONS}

Judging from the sample of countries in the IDB, Table Al reports that both developed and developing economies have now bound virtually 100 percent of their agricultural tariff lines, overall an expansion of coverage of about two-thirds for the developing economies, one-fourth for the developed economies. Uruguay Round adjustments imply reductions of tariff rates on about one-fourth of developed economies' imports, on about one-fifth of developing economies' imports. The developing economies were expected to make smaller cuts, but our results show a larger depth of cut for developing economies. ${ }^{34}$

The figures for scope and depth of cut by the developing economies in the IDB, are probably not representative of developing economies in general. The IDB covers all of the developed economy members of the WTO, but it covers none of the least developed countries, who were not expected to make reductions of their agricultural tariffs. The developing economies in the IDB tend to be those that have implemented significant trade reforms.

Chart A1 converts the extent and depth of tariff cuts by the developing economies into multiples of performance by the developed economies. We see there the same pattern we found for tariffs overall. Developing economies' tariffs are still considerably above those of developed economies; the extent (import coverage) of developing economies' Uruguay Round tariff reductions was smaller. But the depth of cut when we measure by how it will affect trading partners' market access was considerably more by the developing economies - at least for those who are in the IDB.

\section{Tariff quota commitments}

The above figures do not take into account how the minimum access commitments (implemented through tariff quotas) have affected the scope of liberalization. This impact depends, of course, on which of a country's tariffied products have imports below 5 percent of

33 The "after" rate is always the lower of the applied and the post-UR bound rate; hence, the Uruguay Round reduction is never negative.

34 Developing economies' tariff rates tend to be higher (Table A2), we measure the depth of tariff cut by dT/(1+T) which for a given $\mathrm{dT} / \mathrm{T}$ is larger as $\mathrm{T}$ is larger. Negotiating guidelines were not precise, but in GATT/WTO affairs, $d T / T$ is usually the implicit measure for depth of cut. 
base period domestic consumption, and by how much. ${ }^{35}$ At the maximum (i.e., if imports of all tariffied products were below the minimum) minimum access opportunities would affect the 22 percent of tariff lines, or approximately one-third of imports, by value, that were tariffied. Hathaway and Ingco (1996, p. 49) estimate that Japan and Korea's minimum access commitments on rice will result in nearly a million tons per year of new imports, an expansion of world trade in rice of 7.5 percent over its 1992 level. Otherwise, they conclude that "the minimum access commitments will provide relatively little additional access and even less additional trade," no more that 0.5 percent for wheat and sugar. (pp. 48, 49)

\section{TARIFFICATION ABOVE EXISTING LEVELS OF PROTECTION}

On agriculture products as on manufactures, developing economies committed to ceiling bindings above their applied rates. Averaged over the developing economies in the IDB, the average applied rate in the base period was 18 percent, their bound rates average almost 60 percent.

Countries that converted NTBs to tariffs have in some cases posted rates higher than the base year tariff equivalent of those NTBs. Japan, for example, has announced that beginning in April 1999 its tariff on rice will be $\$ 3.05$ per kilo. International Trade Reporter (1998) estimates that this rate is equivalent to 1,000 percent, ad valorem. This rate applies, of course, only to imports in excess of Japan's minimum access commitment. Hathaway and Ingco calculate that Japan's actual base period protection on rice had a tariff equivalent of about 650 percent. ${ }^{36}$ Ingco identifies other instances in which a developed economy's post-UR bound rate is above the tariff equivalent of its base year protection.

\section{SPECIAL SAFEGUARDS}

The provision on special safeguards applies only to products that were subject to tariffication. They allow additional duties to be applied in case of a precisely defined surge of import quantity, or cases of imports at prices below a precisely defined reference level. A member can apply a special safeguard to a product for the remainder of the relevant year, on a shipment by shipment basis, only if the member noted in its schedule of commitments that it claimed the right to (eventually) do so. Thirty-eight members have reserved that right, on varying numbers of products. For all relevant Members combined, these reservations imply a potential for imposing special safeguards on almost 6,100 tariff items. During the period January 1998 through September 1998, volume-based actions were taken by five Members affecting a total of 128 tariff items and price-based actions were also taken by five Members affecting a total of 72 tariff items.

35 The commitments apply to opportunities, as defined by the volume at which the higher tariff quota rate applies. They are not minimum import commitments.

36 The specific duty is above the domestic cost of production, hence only the minimum access commitment will affect the amount of rice Japan imports. 
TAble A1: Agricultural Products: URuguay Round TARIFF Bindings

\begin{tabular}{|l|c|c|c|}
\hline & \multicolumn{2}{|c|}{$\begin{array}{c}\text { Percent of imports } \\
\text { GATT-bound }\end{array}$} & $\begin{array}{c}\text { Post-UR bindings } \\
\text { that reduce } \\
\text { protection }^{\mathrm{a}}\end{array}$ \\
\cline { 2 - 4 } & Pre-UR & Post-UR & \multicolumn{2}{|c|}{} \\
\hline Tariffied products & 66 & 100 & 14 \\
\hline All economies that tariffied & 71 & 100 & 35 \\
\hline Untariffied products & 37 & 100 & 17 \\
\hline Developed Economies & & & \\
\hline Developing Economies & 72 & 100 & 26 \\
\hline Tariffied and untariffied products & 37 & 100 & 17 \\
\hline Developed Economies & & & \\
\hline Developing Economies & & & \\
\hline
\end{tabular}

Notes:

a Tariffied products: percentage (by value) of imports with final-UR bound rates (rates that include reductions) below the tariff equivalent of base period protection. Untariffied products: percentage of imports with final-UR bound rates below base period applied rates.

Source: Finger-Ingco-Reincke, Tables G2. 
Table A2: AVerage Uruguay Round Tariff Cuts on Agricultural Products, AVERAge POST-URUguAY ROUND APPLIED AND BOUND TARIFF LEVELS

\begin{tabular}{|l|c|c|c|}
\hline & $\begin{array}{c}\text { UR } \\
\text { Reduction }^{\mathrm{a}}\end{array}$ & $\begin{array}{c}\text { post-UR } \\
\text { applied rate }^{\mathrm{b}}\end{array}$ & $\begin{array}{c}\text { post-UR bound } \\
\text { rate }^{\mathrm{b}}\end{array}$ \\
\hline Tariffied Lines \\
\hline $\begin{array}{l}\text { All economies that } \\
\text { tariffied }\end{array}$ & 4.4 & 25 & 32 \\
\hline Not tariffied lines & \multicolumn{3}{l}{} \\
\hline $\begin{array}{l}\text { Developed Economies } \\
\text { Developing Economies }\end{array}$ & 1.6 & 5 & 7 \\
\hline Tariffied and not tariffied & 0.9 & 19 & 66 \\
\hline Developed Economies & 1.5 & 14 & 15 \\
\hline Developing Economies & 4.7 & 18 & 60 \\
\hline
\end{tabular}

Notes:

${ }^{a}$ Change measured as $\mathrm{dT} /(1+\mathrm{T})$, expressed as a percentage. Tariffied products: change from the tariff equivalent of base period protection to final-UR bound rate. Untariffied products: change from base period applied rate to the lower of base period applied rate and final-UR bound rate.

${ }^{5}$ Ad valorem equivalent based on 1986-1988 prices.

Source: Finger-Ingco-Reincke, Tables G2. 
CHART A1: COMPARISONS OF EXTENT AND DEPTH OF UR TARIFF CONCESSIONS ON Agricultural Products, of Post-UR bound Rates by Developed aNd by DEVELOPING ECONOMIES

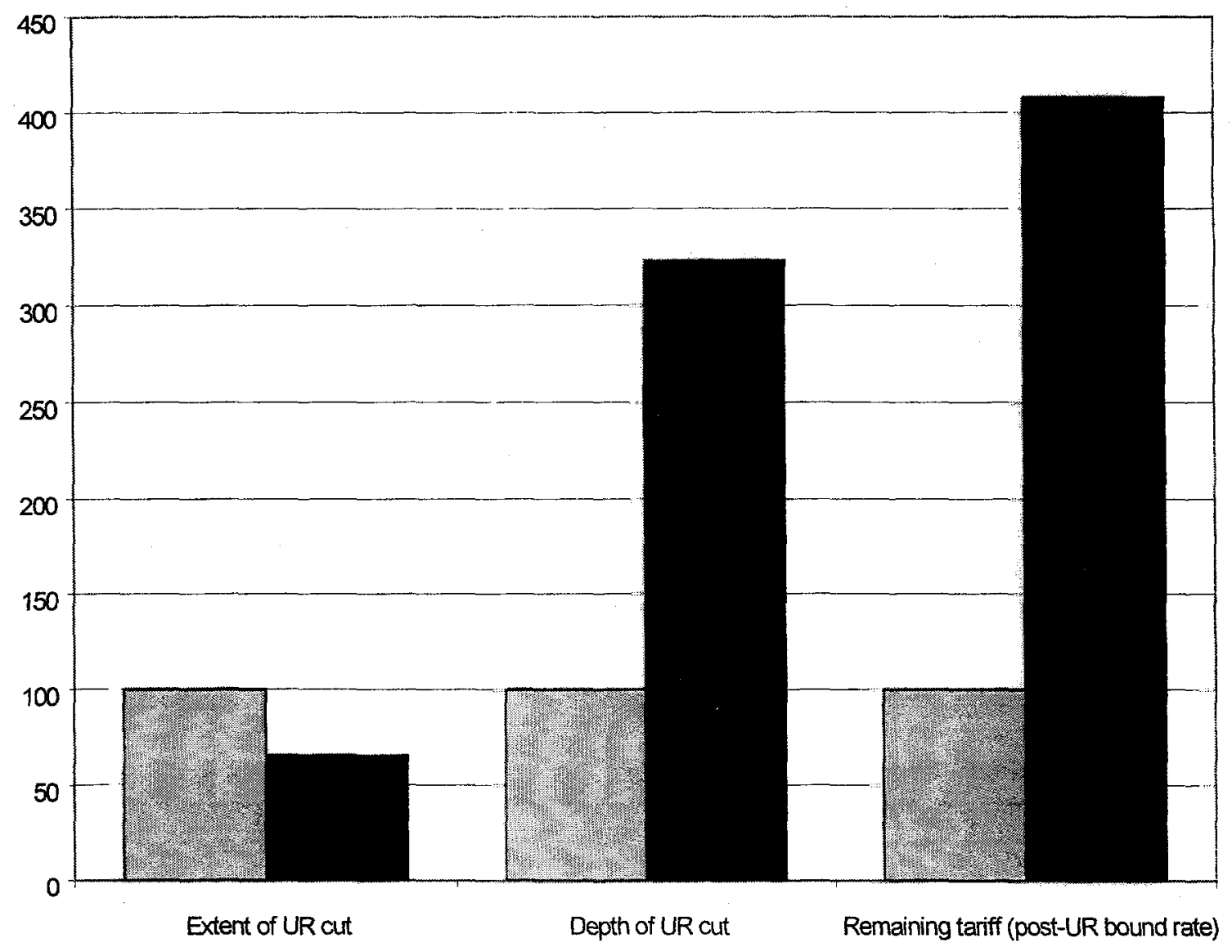

$\square$ Developed Economies

Developing Economies 


\section{ANTIDUMPING}

The Uruguay Round Antidumping Agreement (formally, Agreement on Implementation of Article VI of the GATT 1994) adds considerable detail, e.g.:

- specificity has been added on the required evidence and methodology for determining dumping and injury,

- rules regarding support from domestic industry of the antidumping claim are now spelled out,

- procedural rules for hearing both sides and the time frame of investigations have been tightened,

- a "de minimis" clause (specifying that the dumping margin has to be at least 2 percent) have been added,

- notification requirements are explicit,

- a sunset clause and requirement for review have been added.

\section{DEVELOPING ECONOMIES BECOME MAJOR USERS}

The use of antidumping has spread significantly from the five original industrial country users (Australia, Canada, the EU, New Zealand and the US). In a first wave, a number of advanced developing countries including Mexico, Brazil and Argentina starting using antidumping in the late 1980s. More recently, many smaller and poorer developing countries have sporadically taken recourse to antidumping, so that the total number of countries which have used this means of trade protection now exceeds 30 . The use of antidumping per dollar of imports is notably higher among developing economies than among developed economies.

Among the traditional users of antidumping, the number of initiations has declined since the Uruguay Round Agreements have been in effect, i.e., since January 1, 1995. The filing of a number of antidumping cases by the US steel industry at the time of this writing (March 1999) may however reverse the decline in the United States. Among new users, for which data are available - Argentina, Mexico, Korea and Turkey report an increase in the number of tariff lines the trade covered by antidumping measures. Among the developing economies for which data are available, only Brazil applies antidumping measures to a declining share of tariff lines (Michalopoulos, 1999). Table AD1 along with Charts AD1 and AD2 illustrate the development of antidumping investigations over the 1991-98 period.

Table AD2 contains the countries most frequently affected by antidumping cases between 1992-94 and 1995-97. China has been targeted most frequently during both periods. The United States, one of the most frequent users of antidumping, is also one of the most targeted countries, second after China and targeted more than twice as often as Japan. After China and the US, Korea and Brazil were the main targets during the early 1990s; while Korea, Germany and Taiwan attracted the most investigations in the latter period. Industrial countries mostly target other high income and transition countries, with less than one quarter of the investigations involving developing countries (and about half of those, China). Developing countries by contrast initiate an almost equal share of investigations against either of the three country groups (Miranda, Torres and Ruiz, 1998). As to sectoral distribution, we find that producers of base metals, chemicals, machinery, electrical equipment, plastics and textiles frequently seek antidumping protection. 


\section{UNDERTAKINGS, MAGNITUDE OF ANTIDUMPING MEASURES}

The share of initiated investigations (Table AD3) that lead to a restrictive outcome (provisional measures and affirmative findings) tend to be similar among all the countries in the table - except Australia, where the proportion of cases there that lead to restrictive outcomes, particularly restrictive final outcomes, is notably below the figure for any other country.

Another important dimension of such protection is the use of price undertakings (exporters agreeing to maintain minimum export prices) versus tariffs. For lack of time-series data, we did a tabulation for seven of the main antidumping users for 1997. In this year, only Korea and the EU report a significant share of final measures being price undertakings (Table AD4). In Korea this share exceeds 50 percent, and in the EU 20 percent. In the other 5 countries for which data was readily available, 98-100 percent of final measures consisted of duties.

While the trade coverage of antidumping is small, the level of tariffs applied on average is quite high and has in some instances reached several hundred percent. The last column of Table AD4 provides average duties imposed as part of final measures in the same seven users in 1997. Colombia applies the highest average tariff of 60 percent and Korea the lowest of 28 percent. Four of the other countries apply average rates of 30 to 40 percent. This is very high compared to "normal" average tariffs of about 4 percent on industrial products in developed economies, 8 percent to 12 percent in developing economies. The EU's 40 percent for 1997 are also much higher than the 23 percent applied for the 1980-87 period (Messerlin, 1989).

Because of the sunset clause in the Uruguay Round Agreement, reviews of measures already in place make up an increasing share of investigations. In the EU, 79 out of 190 investigations have been reviews in the 1995 - 1998 period, in the US 116 reviews of measures in place when the Uruguay Round agreements came into effect were conducted in 1998.

\section{WTO DISPUTES OVER ANTIDUMPING CASES}

A variety of disputes regarding procedures, standards for initiating and conducting investigations, as well as substantive elements necessary for imposing duties are emerging. The recent dispute between Guatemala and Mexico on Portland cement has illustrated that the procedural and technical requirements to conduct an antidumping investigation consistent with WTO rules are quite stringent. Many developing countries are likely to find it difficult to meet these requirements and may find themselves increasingly challenged, especially by the highincome countries. Developing economies have not been reluctant to challenge antidumping actions by the developed economies: Korea's case against the US on D-Ram and India's dispute with the EU on unbleached cotton fibers are examples.

The real test of the use or abuse of antidumping, however, may still be lying ahead. In recent years, the world economic climate has been quite favorable, and previous studies have shown that the use of antidumping is strongly correlated with the business cycles (see, e.g., Leidy, 1996). The slowdown in economic growth since the outbreak of the Asian crisis could, with a lag, lead to a rebound in antidumping measures and more retreats in market access commitments. The saber-rattling in the US and the considerable increase in cases by several countries in 1998 are, we hope, a transitory phenomenon. 


\section{ANTIDUMPING AS AFFECTED BY THE ASIAN CRISIS}

One could hypothesize that the Asian crisis would change the pattern of user and target countries for antidumping. As to the Asian countries affected, each experienced a marked currency devaluation, which is likely to reduce import competition and hence pressures for protection. Consistent with this, we found that the five Asian countries affected by crisis initiated fewer new cases but became the target of investigations more often in 1998 as compared to 1997. Korea and Malaysia which had used antidumping to a moderate extent in 1996/97 almost stopped initiating new investigations in 1998. Indonesia continued using antidumping to some degree while Thailand and the Philippines had never been very active users.

As to antidumping initiations against the Asian crisis countries, there is no uniform development althougn some increase has probably taken place. The US and South Africa increased the number of antidumping investigations against South East Asia from 2 to 6 and from 2 to 9 respectively. The European Union, on the other hand, initiated only 4 new cases in 1998 (all of them against Korea) after 10 cases in 1997. Brazil and Mexico neither used antidumping in 1997 nor in 1998 against these countries. (Table AD5)

\section{ANTIDUMPING CASES IN SECTORS WITH NOTABLE LIBERALIZATION}

It could be hypothesized that sectors with disproportionately large liberalization would also report a stronger increase in antidumping cases since the end of the Uruguay Round. However, there is little evidence of this for four of the main user countries. In India use of antidumping has jumped since the end of the Uruguay Round, but it is not obvious that there is a correlation between new antidumping cases and sectoral liberalization. Disproportionate liberalization in wood products (EU, Australia) and in textiles/clothing/footwear (EU) may be responsible for an increase in antidumping claims in these two sectors. (Table AD6) 
TABLE AD1: ANTIDUMPING INITIATIONS BY ECONOMY TAKING ACTION

\begin{tabular}{|l|c|c|c|}
\hline \multirow{2}{*}{ Economy } & \multicolumn{2}{|c|}{ Number of antidumping initiations } & $\begin{array}{c}\text { Index of antidumping } \\
\text { initiations per dollar } \\
\text { of imports, } \\
\text { USA=100. }\end{array}$ \\
\cline { 2 - 4 } & $1991-94$ & $1995-98$ & 1096 \\
\hline Australia & 213 & 77 & 199 \\
\hline Canada & 84 & 39 & 210 \\
\hline EU & 135 & 122 & 100 \\
\hline US & 226 & 94 & 74 \\
\hline $\begin{array}{l}\text { All developed } \\
\text { economies }\end{array}$ & 678 & 353 & 2627 \\
\hline & Developing Economies & 871 \\
\hline Argentina & 59 & 72 & 1875 \\
\hline Brazil & 59 & 54 & 204 \\
\hline India & 15 & 78 & 275 \\
\hline Korea & 14 & 34 & 313 \\
\hline Mexico & 127 & 31 & 2324 \\
\hline South Africa & 16 & $72^{\text {b/ }}$ & \\
\hline $\begin{array}{l}\text { All developing } \\
\text { economies }\end{array}$ & 394 & 509 & \\
\hline
\end{tabular}

Notes:

${ }^{\text {a.l }}$ Based on numbers of antidumping initiations 1995-98 and values of merchandise imports for 1996.

b/ 1995-97 figure.

Source: WTO Secretariat, Rules Division; Antidumping Measures Database 
TABLE AD2: ANTIDUMPING INITIATIONS BY EXPORTING ECONOMY

\begin{tabular}{|l|c|c|c|}
\hline \multirow{2}{*}{ Economy } & \multicolumn{2}{|c|}{ Number of antidumping initiations } & $\begin{array}{c}\text { Index of antidumping } \\
\text { initiations per dollar } \\
\text { of exports, USA=100 }\end{array}$ \\
\cline { 2 - 4 } & \multicolumn{3}{|c|}{ Developed economies } \\
\hline France & 26 & 8 & 34 \\
\hline Germany & 35 & 30 & 70 \\
\hline Italy & 16 & 16 & 77 \\
\hline Japan & 32 & 23 & 67 \\
\hline UK & 20 & 16 & 74 \\
\hline US & 70 & 48 & 100 \\
\hline & \multicolumn{2}{|c|}{ Developing economies } & \\
\hline Brazil & 50 & 23 & 785 \\
\hline China & 115 & 94 & 779 \\
\hline India & 24 & 21 & 385 \\
\hline Korea & 50 & 40 & 323 \\
\hline Taiwan & 31 & 30 & 451 \\
\hline Thailand & 26 & 21 & 751 \\
\hline
\end{tabular}


TABLE AD3: SHARE OF COMPLETED INVESTIGATIONS RESULTING IN PROVISIONAL AND DEFINITIVE MEASURES, 1987-1997

\begin{tabular}{|l|c|c|c|}
\hline & $\begin{array}{c}\text { Number of } \\
\text { Completed } \\
\text { Investigations }\end{array}$ & $\begin{array}{c}\text { Proportion } \\
\text { provisional } \\
\text { measures }\end{array}$ & $\begin{array}{c}\text { Proportion } \\
\text { affirmative } \\
\text { outcome }\end{array}$ \\
\hline United States & 423 & 83 & 64 \\
\hline Canada & 186 & 83 & 63 \\
\hline EC & 308 & 55 & 60 \\
\hline Korea & 43 & 58 & 58 \\
\hline New Zealand & 54 & 39 & 57 \\
\hline Mexico & 182 & 63 & 53 \\
\hline Argentina & 94 & 48 & 51 \\
\hline Brazil & 75 & 41 & 43 \\
\hline South Africa & 62 & 48 & 42 \\
\hline Australia & 408 & 53 & 29 \\
\hline
\end{tabular}

Source: WTO Secretariat, Rules Division; Antidumping Measures Database 
TABle AD4: ANTIDUmPIng Duties vS. Price UNDertakings, 1997

\begin{tabular}{|l|c|c|c|}
\hline & $\begin{array}{c}\text { Share of } \\
\text { affirmative } \\
\text { decisions } \\
\text { ending in duty } \\
\text { (in \%) }\end{array}$ & $\begin{array}{c}\text { Share of } \\
\text { affirmative } \\
\text { decisions ending } \\
\text { in price } \\
\text { undertakings } \\
\text { (in \%) }\end{array}$ & Average duty \\
in $1997^{\text {at }}$ \\
\hline Canada & 98.0 & 2.0 & 34.1 \\
\hline Colombia & 100.0 & 0.0 & 60.3 \\
\hline EC & 79.5 & 20.5 & 40.4 \\
\hline Korea & 46.7 & 53.3 & 27.9 \\
\hline Mexico & 100.0 & 0.0 & 53.7 \\
\hline South Africa & 100.0 & 0.0 & 34.1 \\
\hline US & 99.4 & 0.6 & 30.5 \\
\hline
\end{tabular}

Source: WTO Rules Division; Antidumping Measures Database

${ }^{a}$ In percent; average all final measures per country in 1997; when a decision ended in a range of duties, the mean value was taken. 
TABLE AD5: ANTIDUMPING INITIATIONS AGAINST SOUTH-EAST ASIAN COUNTRIES IN 1997 AND 1998

\begin{tabular}{|l|c|c|c|c|c|c|c|c|c|c|c|c|}
\hline & \multicolumn{2}{|c|}{ Korea } & \multicolumn{2}{c|}{ Indonesia } & \multicolumn{2}{c|}{ Thailand } & \multicolumn{2}{c|}{ Philippines } & \multicolumn{2}{c|}{ Malaysia } & \multicolumn{2}{c|}{ Total } \\
\hline & 1997 & 1998 & 1997 & 1998 & 1997 & 1998 & 1997 & 1998 & 1997 & 1998 & 1997 & 1998 \\
\hline EU & 4 & 4 & 1 & 0 & 2 & 0 & 0 & 0 & 3 & 0 & 10 & 4 \\
\hline US & 2 & 4 & 0 & 2 & 0 & 0 & 0 & 0 & 0 & 0 & 2 & 6 \\
\hline Brazil & 0 & 0 & 0 & 0 & 0 & 0 & 0 & 0 & 0 & 0 & 0 & 0 \\
\hline India & 1 & 3 & 0 & 0 & 0 & 0 & 0 & 0 & 1 & 0 & 2 & 3 \\
\hline Mexico & 0 & 0 & 0 & 0 & 0 & 0 & 0 & 0 & 0 & 0 & 0 & 0 \\
\hline South Africa & 2 & 5 & 1 & 1 & 0 & 0 & 0 & 0 & 1 & 3 & 4 & 9 \\
\hline
\end{tabular}

Source: WTO Secretariat, Rules Division; Antidumping Measures Database 
TABLE AD6: ANTIDUMPING CLAIMS BY SECTORS WITH ABOVE AVERAGE LIBERALIZATION, SELECTED COUNTRIES

\begin{tabular}{|c|c|c|c|c|c|c|c|}
\hline & 1992 & 1993 & 1994 & 1995 & 1996 & 1997 & 1998 \\
\hline \multicolumn{8}{|c|}{ United States } \\
\hline metals & 68 & 15 & 33 & 4 & 8 & 11 & 13 \\
\hline chemicals & 9 & 12 & 7 & 0 & 6 & 0 & 0 \\
\hline other manufacturing & 0 & 2 & 2 & 0 & 0 & 0 & 0 \\
\hline textiles/clothing & 0 & 0 & 0 & 0 & 0 & 0 & 0 \\
\hline \multicolumn{8}{|c|}{ European Union } \\
\hline wood & 1 & 0 & 0 & 1 & 0 & 7 & 0 \\
\hline metals & 9 & 5 & 10 & 7 & 11 & 3 & 15 \\
\hline chemicals & 13 & 5 & 6 & 3 & 0 & 6 & 0 \\
\hline machinery & 13 & 7 & 4 & 10 & 0 & 14 & 0 \\
\hline other manufacturing & 0 & 0 & 0 & 0 & 0 & 0 & 0 \\
\hline textiles/cloth/footwear & 1 & 1 & 17 & 6 & 10 & 8 & 6 \\
\hline \multicolumn{8}{|c|}{ India } \\
\hline wood & 0 & 0 & 0 & 3 & 0 & 0 & $\ldots$ \\
\hline text/clothing & 0 & 0 & 0 & 3 & 0 & 9 & $\ldots$ \\
\hline metals & 0 & 0 & 3 & 0 & 3 & 3 & $\ldots$ \\
\hline chemicals & 1 & 5 & 2 & 1 & 4 & 8 & $\ldots$ \\
\hline machinery & 0 & 0 & 0 & 8 & 0 & 6 & $\ldots$ \\
\hline \multicolumn{8}{|c|}{ Australia } \\
\hline wood & 0 & 8 & 0 & 0 & 0 & 14 & 1 \\
\hline metals & 2 & 3 & 2 & 0 & 0 & 2 & 0 \\
\hline machinery & 2 & 4 & 0 & 1 & 1 & 1 & 0 \\
\hline
\end{tabular}


CHART AD1: ANTIDUMPING - TOTAL NUMBER OF INITIATED INVESTIGATIONS, ALL WTO MEMBERS

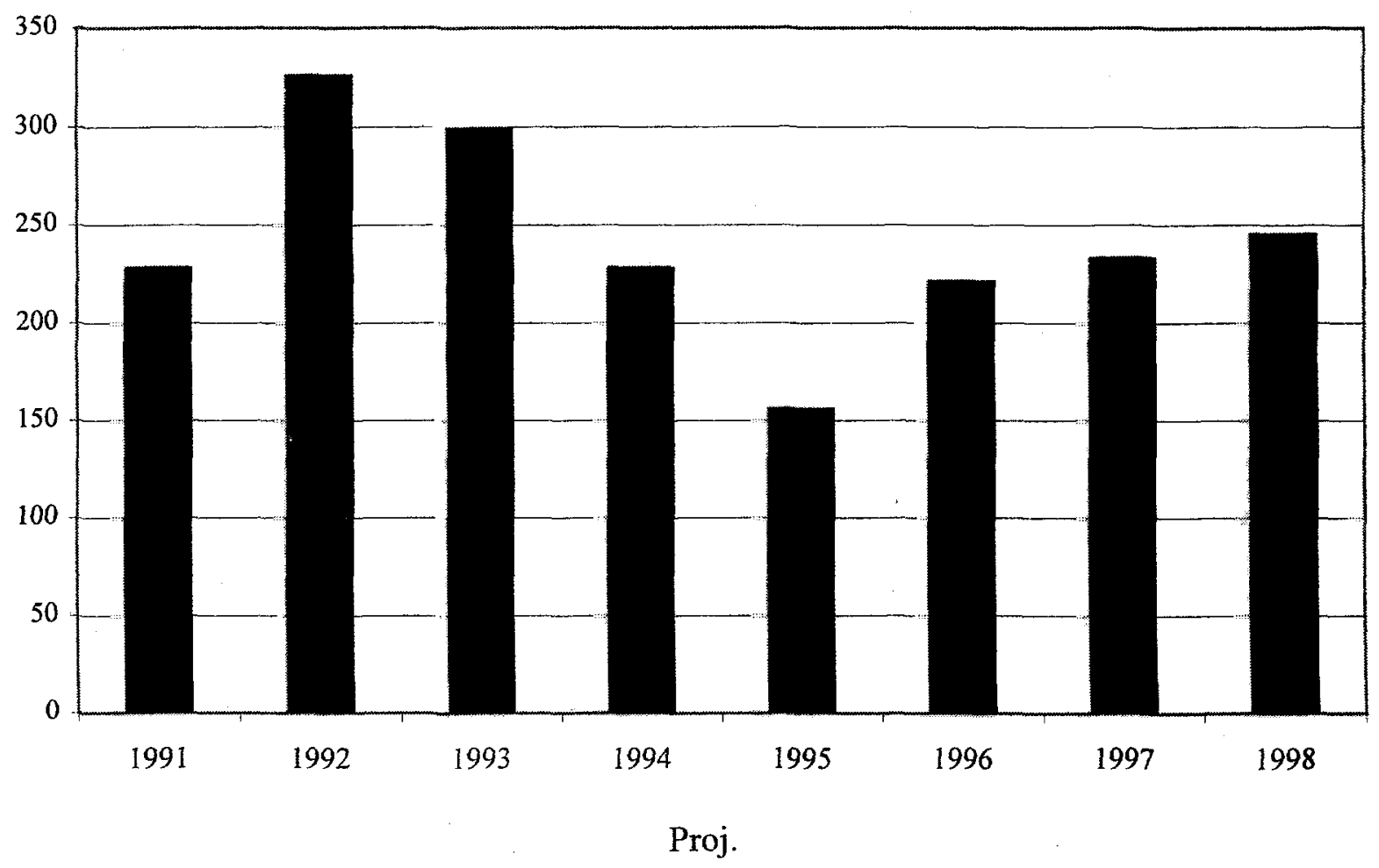

Source: WTO Rules Division; Antidumping Measures database 
CHART AD2: NUMBERS OF ANTIDUMPING INITIATIONS BY DEVELOPED AND BY DEVELOPING ECONOMIES

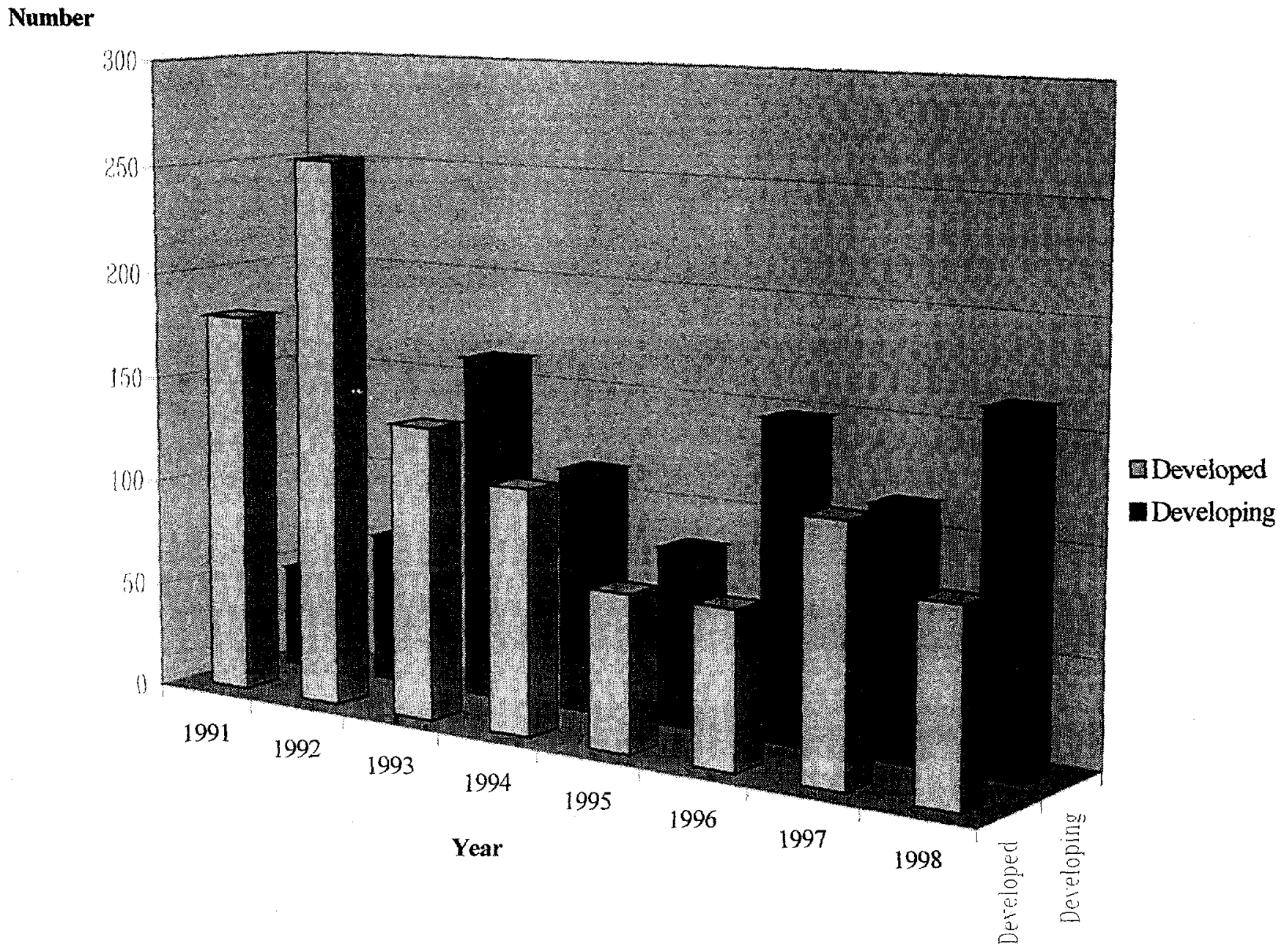




\section{SUBSIDIES, COUNTERVAILING DUTIES}

Like the antidumping rules, the GATT rules on subsidies and countervailing duties were superseded by a comprehensive Uruguay Round Agreement. The Subsidy Agreement distinguishes three types of subsidies. Subsidies contingent upon export performance or on the use of domestic over imported inputs are prohibited. They can lead to both countervailing duties and a dispute settlement case. Subsidies not specific to an enterprise or industry are considered "non-actionable." They can not be subject to countervailing duties or dispute settlement challenges although they can be brought to the Committee on Subsidies and Countervailing Measures if they result in serious adverse effects in another country. All other subsidies are "actionable", i.e., they may be subject to multilateral dispute settlement challenge or to countervailing action if they adversely effect another WTO Member.

Industrial countries had to phase out prohibited subsidies by 1998. Least developed countries have until 2003 to eliminate subsidies contingent on the use of domestic inputs, but are not required to eliminate export subsidies. Other developing countries must eliminate subsidies contingent on the use of domestic inputs by 2000 , export subsidies by 2003 . Special Provisions for transition economies are more complex, involving a requirement that prohibited subsidies be phased out by 2002 , but at the same time providing some lee way to apply programs and measures necessary for transformation from a centrally-planned to a market, free-enterprise economy.

Like in antidumping, the subsidy agreement added considerable specificity on procedures and criteria for a countervailing duty investigation. The agreement also requires that countries notify their specific subsidies (as defined under the Subsidy Agreement) on an annual basis, and countervailing duty activities on a semi-annual basis.

\section{USE OF COUNTERVAILING DUTIES}

There are two notable developments in the use of countervailing duties:

- Overall use has declined considerably since the end of the Uruguay Round, with much of this decline due to the absence of steel cases,

- The EU has become a user of countervailing measures since 1996 after hardly having used this instrument before.

The 1992 to 1994 period saw 137 cases with the US, Australia, Brazil and Mexico being the principal users (Table CV1). The European Community and its individual members, Brazil and South Africa were the main targets of countervailing duty cases for that period. Since the Uruguay Round agreements have come into force, the number of initiations has declined drastically. The 1995-1997 period witnessed only 33 cases, one quarter of the cases during the preceding 3 years. Apart from the US, the EU and New Zealand have become the main users of this provision, with EU countries and South Africa remaining the main targets (Table CV2). Although 1998 data are incomplete at the time of this writing, there are indications that the number of cases will be near the annual rates of 1992-95; considerably higher than the low rates in 1995-97.

Data on the trade coverage of countervailing cases is very limited. The US reports that cases initiated over the past 10 years (1988-1997) affected only 0.7 percent of total US imports. This is a decline by 50 percent compared to the 1984-94 period, when 1.4 percent of imports were affected (US ITC, 1998). We mentioned above that the EU does not report trade coverage 
of countervailing cases separately from antidumping. However, given that the first $\mathrm{EU}$ countervailing case of the 1990s was brought about in 1996 and only 9 cases were reported for 1996/98, trade coverage should be very small. The 4 cases from 1998, for example, affected trade of US\$140 million.

Data on the share of decisions leading to duties versus undertakings and on the average tariff rates are also scarce, but available data for two countries suggest that countervailing duties are much lower than antidumping duties. New Zealand reports two decisions leading to duties and price undertakings, each with an average duty of 7.5 percent. The US notified over 80 percent of decisions leading to duties, and average tariffs only average 4.2 percent.

There were a number of conflicts over the application of the Subsidy Agreement and the use of countervailing duties during the 1995-98 period. With respect to multilateral challenges to subsidies applied by Members, the only adopted dispute settlement panel report (by March 1999) in this area on Indonesia's national car program was decided in favor of the plaintiff, the EU. However, a number of other subsidies panels are ongoing as of this writing, mostly dealing with subsidies that the plaintiff interprets to be in the prohibited category. There are also in process a number of cases on the application of countervailing measures.

Notifications regarding subsidies and countervailing duties seem to be provided relatively regularly. However, developing countries report subsidy data much less frequently, and all subsidy notifications are frequently late and incomplete.

There are no firm plans for new negotiations in this area, but some challenges remain. Given the upcoming deadlines to bring Members' subsidy schemes in line with WTO rules, there is considerable concern about developing and transition countries' ability to meet these deadlines. 
TABLE CV1: NUMBERS OF INITIATIONS OF COUNTERVAILING DUTY INVESTIGATIONS, BY INITIATING MEMBER

\begin{tabular}{|l|c|c|}
\hline \multirow{2}{*}{ Country } & \multicolumn{2}{|c|}{$\begin{array}{c}\text { Number of initiations } \\
\text { by country }\end{array}$} \\
\cline { 2 - 3 } & $1992-94$ & $1995-97$ \\
\hline Argentina & 4 & 3 \\
\hline Australia & 19 & 1 \\
\hline Brazil & 23 & 0 \\
\hline Canada & 2 & 3 \\
\hline Chile & 8 & 0 \\
\hline EU & 0 & 5 \\
\hline Mexico & 16 & 1 \\
\hline New Zealand & 0 & 6 \\
\hline USA & 60 & 10 \\
\hline Other & 5 & 4 \\
\hline Total & 137 & 33 \\
\hline
\end{tabular}

Source: WTO Secretariat, Rules Division; Countervailing Measures Database 
TABLE CV2: NUMBERS OF INITIATIONS OF COUNTERVAILING DUTY INVESTIGATIONS, BY AFFECTED (EXPORTER) MEMBER

\begin{tabular}{|l|c|c|}
\hline \multirow{2}{*}{ Country } & \multicolumn{2}{|c|}{$\begin{array}{c}\text { Number of initiations } \\
\text { against country }\end{array}$} \\
\cline { 2 - 3 } & $1992-94$ & $1995-97$ \\
\hline Brazil & 13 & 1 \\
\hline Canada & 4 & 2 \\
\hline EC & 12 & 5 \\
\hline Germany & 6 & 1 \\
\hline India & 4 & 4 \\
\hline Italy & 6 & 6 \\
\hline South Africa & 10 & 3 \\
\hline US & 7 & 1 \\
\hline Venezuela & 5 & 1 \\
\hline Other & 70 & 9 \\
\hline Total & 137 & 33 \\
\hline
\end{tabular}

Source: WTO Secretariat, Rules Division; Countervailing Measures Database 


\section{SAFEGUARDS}

The Agreement on Safeguards specifies the rules for the application of Article XIX emergency action measures. Under the agreement, action can be taken against imports only a determination of "serious" injury caused or threatened to be caused by imports. ${ }^{37}$ Either quantitative restrictions or duty increases beyond bound rates are allowed, but measures are time bound and must be progressively reduced. The need to make compensation and the right of exporters to retaliate can be avoided by keeping the restrictive measure within certain parameters. ${ }^{38}$ This restriction on compensation-retaliation was intended to make the use of safeguards measures more attractive, and aims at preventing the re-emergence of voluntary export restraints or orderly marketing arrangements. The agreement also requires that existing safeguard measures be notified and phased out according a schedule similar to the sunset provision that applies to new measures.

There has been a minor increase in cases since the Uruguay Round agreement came into effect, but safeguards remain an infrequently used trade remedy - only 19 safeguard investigations initiated 1995-97 as compared with 33 countervailing duty investigations and over 600 antidumping initiations. ${ }^{39}$ (Table SG1)

Total imports affected by investigations amounted to about 2 billion US $\$$ between 1995 and 1998, or about one quarter of one percent of annual imports of the countries initiating investigations. ${ }^{40}$ Two of the eight cases which have been decided affirmatively resulted in a quantitative restriction, the other six in tariffs. Import quotas were allocated in both cases on the basis of previous relative import shares. Four cases were terminated or ended in a negative decision, and four decisions were outstanding at the time of this writing.

Our findings on safeguards confirm earlier findings that market access retreats through existing provisions have so far been limited. At the same time, the new UR Agreements have been successful in curtailing protection outside the multilateral framework. Between 1995 and spring 1999, there have been no complaints that the prohibition of gray area measures under Article 11 of the SGA has been violated. Anticipation that degressive and time-bound safeguard measures would replace antidumping as an instrument for dealing with specific import problems has not been have been realized.

\footnotetext{
${ }^{37}$ There seems to be a legal consensus that "serious injury" is a somewhat higher level of injury than "material injury" as specified under antidumping and countervailing duty rules. The difference is however difficult to isolate in an accounting or economic sense.

${ }^{38}$ The conditions are provided in the WTO homepage under www.wto.org/WTO/goods/safeguar.htm.

${ }^{39}$ Finger (1998) demonstrates that the various trade remedies the GATT/WTO permits are quite fungible.

${ }^{40}$ The five cases by the US covered in total about 0.15 percent of US annual imports, the two cases by Argentina covered 1 percent of Argentine imports.
} 
TABLE SG1: SAFEGUARD INVESTIGATIONS INITIATIONS, 1991-1998

\begin{tabular}{|l|c|c|c|c|c|c|c|c|c|c|}
\hline Country & 1991 & 1992 & 1993 & 1994 & $\begin{array}{c}\text { Total } \\
\mathbf{1 9 9 1 - 9 4}\end{array}$ & 1995 & 1996 & 1997 & 1998 & $\begin{array}{c}\text { Total } \\
\mathbf{1 9 9 5}-\mathbf{9 8}\end{array}$ \\
\hline Argentina & & & & & $\mathbf{0}$ & & & 1 & 1 & $\mathbf{2}$ \\
\hline Australia & & & & & $\mathbf{0}$ & & & & 1 & $\mathbf{1}$ \\
\hline Austria & 1 & & 1 & & $\mathbf{2}$ & & & & & $\mathbf{0}$ \\
\hline Brazil & & & & & $\mathbf{0}$ & & 1 & & & $\mathbf{1}$ \\
\hline Canada & & & 1 & & $\mathbf{1}$ & & & & & $\mathbf{0}$ \\
\hline Czech \& Slovak & 1 & & & & $\mathbf{1}$ & & & & & $\mathbf{0}$ \\
\hline EEC & 3 & & 1 & & $\mathbf{4}$ & & & & & $\mathbf{0}$ \\
\hline Egypt & & & & & $\mathbf{0}$ & & & & 1 & $\mathbf{1}$ \\
\hline Hungary & & 3 & & & $\mathbf{3}$ & & & & & $\mathbf{0}$ \\
\hline India & & & & & $\mathbf{0}$ & & & 1 & 5 & $\mathbf{6}$ \\
\hline Korea & & & & & $\mathbf{0}$ & 1 & 2 & & & $\mathbf{3}$ \\
\hline USA & & & & & $\mathbf{0}$ & 1 & 2 & 1 & 1 & $\mathbf{5}$ \\
\hline All countries & 5 & 3 & $\mathbf{3}$ & $\mathbf{0}$ & $\mathbf{1 1}$ & 2 & 5 & 3 & 9 & $\mathbf{1 9}$ \\
\hline
\end{tabular}


TABLE SG2: SAFEGUARD MEASURES, SINCE 1/95

\begin{tabular}{|c|c|c|c|c|c|c|c|}
\hline $\begin{array}{l}\text { Notifying } \\
\text { Member }\end{array}$ & $\begin{array}{l}\text { Type of Product } \\
\text { concerned }\end{array}$ & $\begin{array}{l}\text { Import Value, } \\
\text { Year prior to } \\
\text { Investigation } \\
\text { (Million US \$) } 1 /\end{array}$ & $\begin{array}{l}\text { Share of Total } \\
\text { Merchandise } \\
\text { Imports (\%) }\end{array}$ & $\begin{array}{l}\text { Initiation of } \\
\text { Investigation } \\
\quad \text { (Year) }\end{array}$ & $\begin{array}{c}\text { Outcome of } \\
\text { Injury } \\
\text { Investigation }\end{array}$ & \multicolumn{2}{|c|}{ Type of Measure \& Quantification /2 } \\
\hline Argentina & $\begin{array}{l}\text { Footwear } \\
\text { Toys }\end{array}$ & $\begin{array}{l}116.6 \\
155.1\end{array}$ & $\begin{array}{l}0.49 \\
0.51\end{array}$ & $\begin{array}{l}1997 \\
1998\end{array}$ & $\begin{array}{l}\text { affirmative } \\
\text { ongoing }\end{array}$ & Tariff & $\begin{array}{l}4.96 \text { \$ per pair (average), } \\
4.04 \text { \$ per pair (average) }\end{array}$ \\
\hline Australia & Swinemeat & 27.6 & 0.04 & 1998 & affirmative & & $\ldots$ \\
\hline Brazil & Toys & 133.1 & 0.25 & 1996 & affirmative & Tariff & $43 \%, 29 \%, 15 \%$ plus $20 \%$ regular tariff \\
\hline$\overline{\text { Egypt }}$ & Safety matches & 1.7 & 0.01 & 1998 & affirmative & Tariff & $34 \%, 22 \%, 11 \%$ plus $30 \%$ regular tariff \\
\hline \multirow[t]{5}{*}{ India } & $\begin{array}{l}\text { Acetylene black } \\
\text { Carbon black }\end{array}$ & $\begin{array}{l}\cdots \\
24.5\end{array}$ & $\begin{array}{l}\cdots \\
0.07\end{array}$ & $\begin{array}{l}1997 \\
1998\end{array}$ & $\begin{array}{l}\text { affirmative } \\
\text { affirmative }\end{array}$ & $\begin{array}{l}\text { Tariff } \\
\text { Tariff }\end{array}$ & $\begin{array}{l}18 \% \text { up to } \operatorname{Re} 12,950 / \text { metric tonne, } 5 \% \\
\text { up to } \operatorname{Re} 8,830 / \text { metric tonne } / 3 \\
10 \%\end{array}$ \\
\hline & Slabstock polyol & 13.1 & 0.04 & 1998 & ongoing & & \\
\hline & Propylene glycol & 3.4 & 0.01 & 1998 & ongoing & & $\therefore$ \\
\hline & Hardboard & 0.2 & 0.00 & 1998 & negative & & None \\
\hline & $\begin{array}{l}\text { Styrene butadiene } \\
\text { rubber }\end{array}$ & $\cdots$ & $\cdots$ & 1998 & $\begin{array}{l}\text { terminated on } \\
01.05 .98\end{array}$ & & None \\
\hline \multirow[t]{3}{*}{ Korea } & Soybean oil & $\ldots$ & $\ldots$ & 1995 & affirmative & & None \\
\hline & Dairy Products & 69.4 & 0.05 & 1996 & affirmative & $\begin{array}{l}\text { Import } \\
\text { Quota }\end{array}$ & $\begin{array}{l}\text { rising from } 55.6 \text { to } 65.2 \% \text { of pre- } \\
\text { investigation imports }\end{array}$ \\
\hline & Bicycles \& parts & 38.9 & 0.03 & 1996 & affirmative & & None \\
\hline \multirow[t]{5}{*}{ USA } & Tomatoes & 191.9 & 0.03 & 1995 & negative & & None \\
\hline & $\begin{array}{l}\text { Brooms } \\
\text { Tomatoes \& } \\
\text { peppers }\end{array}$ & $\begin{array}{l}12.1 \\
843.1\end{array}$ & $\begin{array}{l}0.00 \\
0.10\end{array}$ & $\begin{array}{l}1996 \\
1996\end{array}$ & $\begin{array}{l}\text { affirmative } \\
\text { negative }\end{array}$ & Tariff & $\begin{array}{l}33 \%, 32.5 \%, 32.1 \% \text { from } 32 \% \text { current } \\
\text { bound rate } \\
\text { None }\end{array}$ \\
\hline & Wheat gluten & 90.5 & 0.01 & 1997 & affirmative & $\overline{Q R}$ & $\ldots$ \\
\hline & Lamb meat & 123.5 & 0.01 & 1998 & ongoing & & \\
\hline & & $\begin{array}{c}\text { Total } \\
1,844.7\end{array}$ & $\begin{array}{l}\text { Average across } \\
\text { countries } \\
0.24\end{array}$ & & & & \\
\hline
\end{tabular}

Source: Notifications submitted by Member Countries to the WTO Committee on Safeguards.

$1 /$ the year closest to the initiation of the investigation was chosen, in most cases this was the year prior to it

$2 /$ more than one figure for one measure describes the steps of progressive liberalization.

$3 /$ a duty charged up to a maximum of value ( $\mathrm{Re}$ ) per quantity (metric tonnes). 


\section{SERVICES}

Since the Uruguay Round, the multilateral trading system includes disciplines and liberalization commitments covering trade in services. Although experts who have reviewed the outcome of the negotiations have concluded that the first round of services negotiations did not result in far-reaching trade liberalization, they also point out that the importance of bringing services under the multilateral umbrella of the WTO should not be underestimated (Snape, 1998; Hoekman, 1996). In most countries, at least half of GDP is generated in the services sectors and the share is increasing. At the same time less than one quarter of world trade, as reported in countries' balance-of-payments, is in services; 60 percent of which falls under tourism and transport. Low, Mattoo and Schuknecht (1999) show that trade-openness in most services sectors is still much lower than in merchandise trade, and further technical progress and market opening could hence create enormous new trading opportunities.

\section{THE AGREEMENT}

The rights and obligations of WTO Members regarding services trade are specified in the General Agreement on Trade in Services (GATS). Many GATS obligations parallel those of the GATT, although there are important structural differences between the two agreements. National treatment, for example is an unconditional obligation under GATT but negotiable under the GATS. It applies only to sectors that a country itself specifies in its schedule of commitments and can be made subject to limitations even in these cases. Moreover, the GATS permits exempting measures from the most-favored-nation treatment for limited periods. ${ }^{4}$ The GATS, like the GATT, provides for the withdrawal of commitments for Balance-of-Payment reasons (Article XII), and under general exceptions (Article XIV). It contains a broad carve-out for prudential reasons in financial services (Annex on Financial Services) and establishes a framework for modifications of schedules (Article XXI). In some areas, negotiations on the need for and possible content of specific rules are still ongoing (see also Croome, 1996 and 1998).

Like the tariff agreements under the GATT, the GATS provides no special monitoring system for Members' compliance to their commitments. The small number of complaints and conflicts brought to the Services Committee and the Dispute Settlement Body suggest that compliance is so far not a big problem. Early dispute settlement cases have however helped to establish important principles. The banana case against the European Union, for example, established that GATS commitments must not be impaired indirectly - in the bananas case, through the application of trade measures on goods that would otherwise be allowed.

\section{LIBERALIZATION}

The GATS schedules of commitments are structured along three dimensions; (i) sector, ${ }^{42}$ (ii) type of commitment (essentially market access and national treatment), and (iii) mode of supply. Unlike the GATT, the GATS covers not only cross-border trade (mode 1) but also consumption abroad (mode 2), foreign commercial presence (mode 3 ), and the movement of

\footnotetext{
${ }^{41}$ Slightly more than half of the WTO membership has used this possibility and annexed MFN exemptions to their schedules.

${ }^{42}$ Members in making commitments for specified sectors usually followed from a nomenclature prepared to facilitate negotiations. That nomenclature divides services activities into some 160 sectors.
} 
natural persons (mode 4). ${ }^{43}$ GATS commitments are based on a positive list, i.e., apply only to sectors explicitly listed in schedules. A country that makes a commitment for a sector for a type of commitment say, national treatment, may however put limitations on that commitment.

Country schedules vary from one page covering one subsector to more than 100 pages covering most services sectors. Malaysia, for example, has made commitments in the largest number of sectors (over 130), and another 30 countries have made commitments in over 100 sub-sectors. Almost all WTO Members have made commitments in tourism, but only 10 regarding rail services.

Tables S1 and S2 present a tally of Members' commitments under the most frequently used modes of delivery, mode 1 (cross border) and mode 3 (commercial presence). ${ }^{44}$ The table lists the numbers of countries that have made national treatment and market access commitments in the most important service sectors. The information in Tables S1 and S2 is summarized in Tables S3 and S4. ${ }^{45}$ We see in Table S3 that across all of the sectors, developing economies agreed to allow unlimited cross-border market access to foreign sellers in only 8 percent of the country-sector possibilities. Developed economies were even less forthcoming, granting full cross-border access in only 7 percent of the country-sector possibilities. There are even fewer unrestricted commitments to allow foreign sales through a foreign commercial presence. Overall, there were slightly more commitments to allow unqualified national treatment to foreign sellers.

While Table S3 asks how many countries granted unrestrained access to foreign sellers, Table S4 asks how many countries granted at least some access, e.g., allowed foreign commercial presence but limited the size of the foreign establishment, allowed cross-border access to some forms of banking deposits but not to others. By this standards, the Uruguay Round outcome is more optimistic. The developed economies accepted some cross border access in more than $2 / 3$ of the instances, and agreed to allow some form of foreign commercial presence in almost all sectors. Developing economy commitments were more restricted, allowing some form of cross-border market access in about $1 / 4$ of instances, allowing some foreign commercial presence and some dimensions of national treatment for foreign establishments in about $1 / 3$ of the tabulated instances.

The obvious message is that the agreement provides a substantial start toward opening international markets for services, but nearly all liberalization commitments are qualified in some way, especially commitments by developing economies.

${ }^{43}$ Examples: tourist travel abroad (mode 2), buying an insurance policy from a foreign-owned but domestically established branch office (mode 3), and the temporary contract for a business consultant abroad (mode 4). Trade statistics comparing trade across modes are limited and it is often difficult to pin down just what available statistics describe. Based on information available for the US, mode 3 trade (sales by foreign branches of US companies) in financial, insurance and recreational services is considerably larger than mode 1 trade (purchases by foreigners from a US-located source). In business services, trade in the two modes is about equal. Only in telecom services does mode 1 trade - trade across borders - appear to be larger than the corresponding mode 3 trade (Low, Mattoo and Schuknecht, 1999).

${ }^{44}$ Mode 2 appears less important in many areas (except tourism) and commitments there often mirrors mode 1 commitments. Mode 4 (movement of natural persons) commitments are very limited for all countries.

${ }^{45}$ As to how the summary tables were constructed, the category "Professional Services" in Tables S1 and S2 includes four sectors. Our tabulation covers 105 developing economies and 26 developed economies, hence in Table S3 in the first line, there were a possible total of (a) 105 developing economies times 4 sectors, or 420 access commitments by developing economies and of (b) 26 developed economies times 4 sectors, or 104 access commitments by developed economies. 
What challenges do these findings pose? Article XIX of the GATS sets January 1, 2000 as the deadline to start new negotiations in services. Given the relatively limited liberalization commitments, negotiations should focus on improving market access conditions (Croome, 1998). Liberalization across all sectors, countries and modes should open up considerable new trading opportunities.

Some further development of GATS rules is already mandated in the Agreement itself, and more may be necessary. Effective disciplines on domestic regulation as embedded in professional qualifications, licensing requirements, and technical standards may also be an important issue to prevent such measures from being unnecessarily trade distortive. Furthermore, regulatory principles aiming at effective competition and independent regulatory oversight as agreed for the basic telecom sector, could be a precedent for other sectors where previous monopolies are gradually exposed to competition.

Finally, it is worthwhile mentioning that the trade potential in services is not only constrained by trade policies in many developing countries. A weak services infrastructure and problems in identifying export opportunities can also be a severe obstacle to services trade development. Nevertheless, it is likely that trade liberalization in conjunction with technical progress (e.g. electronic commerce) will much expand services trade and the boundary of what is tradable in the future (Bacchetta, Low, Mattoo, Schuknecht, Wager and Wehrens, 1998). 
TABle S1: Mode 1 CommitMents in SeleCted Services Sectors

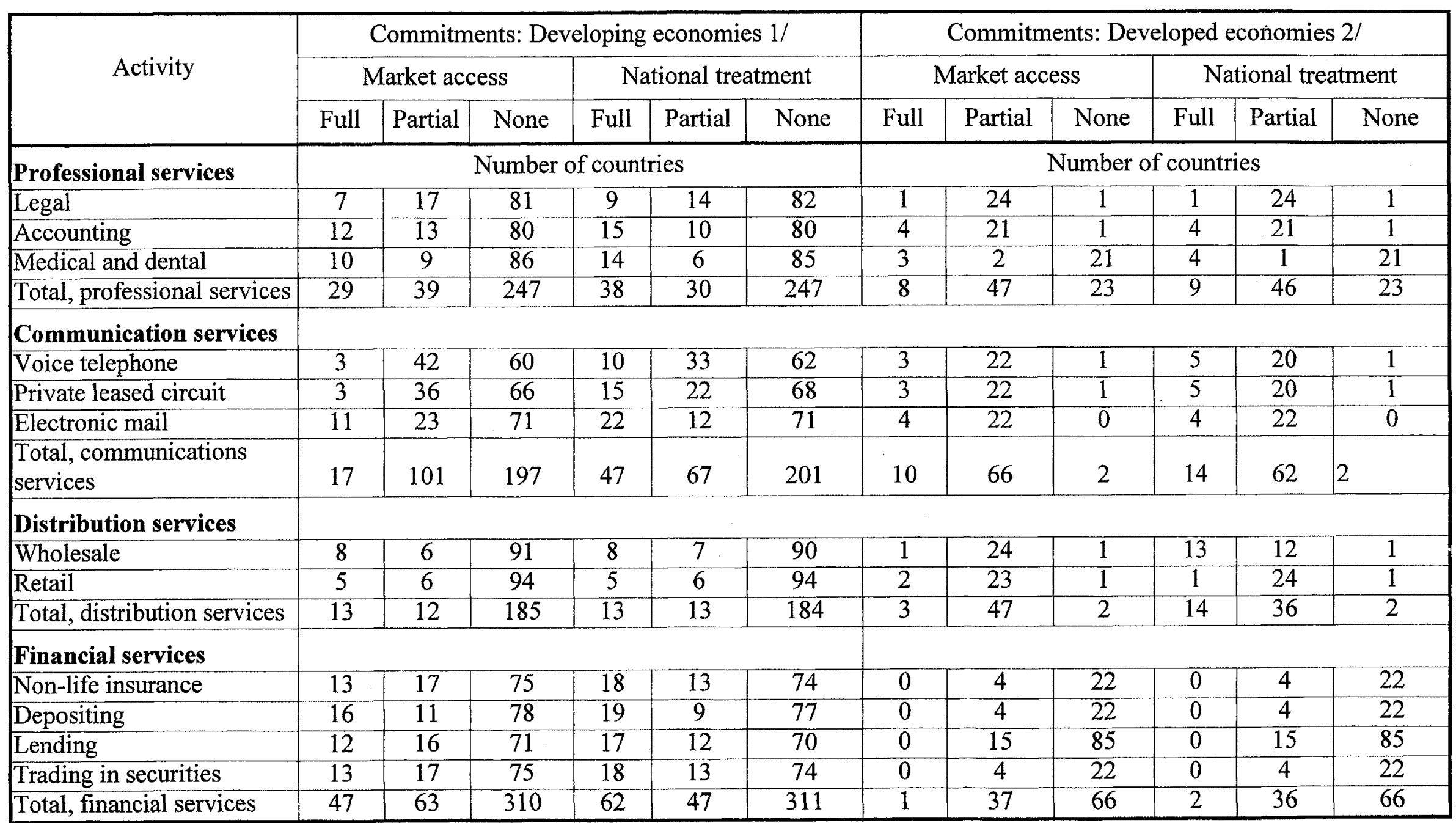

Source: WTO Secretariat

1/ Total of 105 Members

2/ Total of 26 Members 
TABLE S2: MODE 3 COMMITMENTS IN SELECTEd Services Sectors

\begin{tabular}{|c|c|c|c|c|c|c|c|c|c|c|c|c|}
\hline \multirow{3}{*}{ Activity } & \multicolumn{6}{|c|}{ Commitments: Developing economies $1 /$} & \multicolumn{6}{|c|}{ Commitments: Developed economies 2/ } \\
\hline & \multicolumn{3}{|c|}{ Market access } & \multicolumn{3}{|c|}{ National treatment } & \multicolumn{3}{|c|}{ Market access } & \multicolumn{3}{|c|}{ National treatment } \\
\hline & Full & Partial & None & Full & Partial & None & Full & Partial & None & Full & Partial & None \\
\hline & \multicolumn{6}{|c|}{ Number of countries } & \multicolumn{6}{|c|}{ Number of countries } \\
\hline \multicolumn{13}{|l|}{ Professional services } \\
\hline Legal & 2 & 26 & 77 & 7 & 21 & $\overline{77}$ & 0 & 24 & 2 & 0 & 24 & 2 \\
\hline Accounting & 4 & 36 & 65 & 15 & 24 & 66 & 1 & 25 & 0 & 3 & 23 & 0 \\
\hline Medical and dental & 8 & 21 & 76 & 16 & 12 & 77 & 0 & 16 & 10 & 1 & 16 & 9 \\
\hline Total, professional services & 14 & 83 & 218 & 38 & 57 & 220 & 1 & 65 & 12 & 4 & 63 & 11 \\
\hline \multicolumn{13}{|l|}{ Communication services } \\
\hline Voice telephone & 4 & 46 & 55 & 8 & 39 & 58 & 0 & 25 & 1 & 2 & 23 & 1 \\
\hline Private leased circuit & 2 & 39 & 64 & 13 & 24 & 68 & 0 & 25 & 1 & 2 & 23 & 1 \\
\hline Electronic mail & 3 & 32 & 70 & 20 & 14 & 71 & 1 & 25 & 0 & 3 & 23 & 0 \\
\hline $\begin{array}{l}\text { Total, communications } \\
\text { services }\end{array}$ & 9 & 117 & 189 & 41 & 77 & 197 & 1 & 75 & 2 & 7 & 69 & 2 \\
\hline \multicolumn{13}{|l|}{ Distribution services } \\
\hline Wholesale & 6 & 14 & 85 & 6 & 13 & 86 & 0 & 25 & 1 & 0 & 25 & 1 \\
\hline Retail & 2 & 15 & 88 & 3 & 15 & 87 & 1 & 24 & 1 & 0 & 25 & 1 \\
\hline Total, distribution services & 8 & 29 & 173 & 9 & 28 & 173 & 1 & 49 & 2 & 0 & 50 & 2 \\
\hline \multicolumn{13}{|l|}{ Financial services } \\
\hline Non-life insurance & 5 & 40 & 60 & 9 & 34 & 62 & 0 & 26 & 0 & 0 & 26 & 0 \\
\hline Depositing & 11 & 44 & 50 & 13 & 42 & 50 & 1 & 24 & 1 & 0 & 25 & 1 \\
\hline Lending & 11 & 41 & 53 & 11 & 41 & 53 & 1 & 24 & 1 & 0 & 25 & 1 \\
\hline Trading in securities & 8 & 37 & 60 & 6 & 39 & 60 & 1 & 25 & 0 & 0 & 26 & 0 \\
\hline Total, financial services & 35 & 162 & 223 & 39 & 156 & 225 & 3 & 99 & 2 & 0 & 102 & 2 \\
\hline
\end{tabular}


TABle S3: PerCentages of DeVEloping aNd OF DEVEloped ECONOMIES

THAT GAVE FULL MARKET ACCESS OR FULL NATIONAL TREATMENT

COMMITMENTS ON SELECTED SERVICE SECTORS

\begin{tabular}{|l|c|c|c|c|}
\hline & \multicolumn{2}{|c|}{ Market Access } & \multicolumn{2}{c|}{ National treatment } \\
\hline $\begin{array}{l}\text { Cross border provision } \\
\text { (Mode 1) }\end{array}$ & $\begin{array}{c}\text { Developing } \\
\text { Economies }\end{array}$ & $\begin{array}{c}\text { Developed } \\
\text { Economies }\end{array}$ & $\begin{array}{c}\text { Developing } \\
\text { Economies }\end{array}$ & $\begin{array}{c}\text { Developed } \\
\text { Economies }\end{array}$ \\
\hline Professional services & 9 & 10 & 12 & 12 \\
\hline Communication services & 5 & 13 & 15 & 18 \\
\hline Distribution services & 6 & 6 & 6 & 27 \\
\hline Financial services & 11 & 1 & 15 & 2 \\
\hline All selected sectors & 8 & 7 & 13 & 13 \\
\hline \hline & \multicolumn{2}{|c|}{ Market Access } & National treatment \\
\hline Commercial presence & Developing & Developed & Developing & Developed \\
(Mode 3) & Economies & Economies & Economies & Economies \\
\hline Professional services & 9 & 10 & \multicolumn{1}{c|}{12} & 12 \\
\hline Communication services & 5 & 13 & \multicolumn{1}{c|}{15} & 18 \\
\hline Distribution services & 4 & 2 & 4 & 0 \\
\hline Financial services & 8 & 3 & & 0 \\
\hline All selected sectors & 5 & 2 & 10 & 4 \\
\hline
\end{tabular}

Source: Tabulated from Table S1. 
Table S4: Percentages of Developing and of DeVeloped Economies That Made SOME MARKET ACCESS OR SOME NATIONAL TREATMENT COMMITMENTS ON SELECTED SERVICE SECTORS

\begin{tabular}{|l|c|c|c|c|}
\hline & \multicolumn{2}{|c|}{ Market Access } & \multicolumn{2}{c|}{ National treatment } \\
\hline $\begin{array}{l}\text { Cross border provision } \\
\text { (Mode 1) }\end{array}$ & $\begin{array}{c}\text { Developing } \\
\text { Economies }\end{array}$ & $\begin{array}{c}\text { Developed } \\
\text { Economies }\end{array}$ & $\begin{array}{c}\text { Developing } \\
\text { Economies }\end{array}$ & $\begin{array}{c}\text { Developed } \\
\text { Economies }\end{array}$ \\
\hline Professional services & 22 & 71 & 22 & 71 \\
\hline Communication services & 37 & 97 & 36 & 97 \\
\hline Distribution services & 12 & 96 & 12 & 96 \\
\hline Financial services & 26 & 37 & 26 & 37 \\
\hline All selected sectors & 25 & 70 & 25 & 70 \\
\hline \hline & Market Access & National treatment \\
\hline $\begin{array}{l}\text { Commercial presence } \\
\text { (Mode 3) }\end{array}$ & $\begin{array}{c}\text { Developing } \\
\text { Economies }\end{array}$ & $\begin{array}{c}\text { Developed } \\
\text { Economies }\end{array}$ & $\begin{array}{l}\text { Developing } \\
\text { Economies }\end{array}$ & $\begin{array}{l}\text { Developed } \\
\text { Economies }\end{array}$ \\
\hline Professional services & 22 & 71 & 22 & 71 \\
\hline Communication services & 37 & 97 & 36 & 97 \\
\hline Distribution services & 18 & 96 & 18 & 96 \\
\hline Financial services & 47 & 98 & 46 & 98 \\
\hline All selected sectors & 36 & 94 & 35 & 95 \\
\hline
\end{tabular}

Source: Tabulated from Table S2. 


\section{SUMMARY FINDINGS}

The Uruguay Round was the biggest market access round ever. Measured across its coverage of access to markets for merchandise, its tariff reductions - when the 1997 agreement on information technology products is included - exceeds the approximately 35 percent shares of world imports covered by the Kennedy and Tokyo Rounds. In addition, the Uruguay Round agreement eliminated VERs and made significant progress to eliminate developed economies' quantitative restrictions on imports of textiles and clothing and all economies' NTBs on imports of agricultural products.

\section{TARIFF CUTS}

Various reports of the round described the depth of the tariff cut as "one-third," or even as "a forty percent cut." When we take into account imports on which tariffs were not reduced (including those duty-free when the round began) and when we follow a formula for the tariff reduction that measures how much more an exporter will be able to retain from a dollar of expenditure by an importer, we come to more modest figures. Export sales to industrial countries will retain about 1 percent more than without the Uruguay Round cuts, exports sales to developing countries will retain about 2.3 percent more. Applied to 1997 world imports (excluding intra- trade area imports) of some 3.6 trillion dollars $\left(\$ 3.6 \times 10^{12}\right)$ that comes to $\$ 50$ billion/year more for exporters. ${ }^{46}$

Developing economies (except for some of the least developed countries) were full participants in the market access negotiations. Their tariff reductions covered as large a share of their imports as did those of the developed economies, their tariff cuts - when measured by how they will affect exporters' receipts - were deeper than those of the developed economies. The percentage of imports covered by GATT-bound rates is now almost as high for the developed economies as for the developed.

\section{QUANTITATIVE RESTRICTIONS}

The Uruguay Round safeguard agreement requires the phasing out of all existing safeguard (GATT Article XIX) measures and all VERs and other restraints that would not be legal under the Uruguay Round safeguard rules. Good evidence indicates that these measures are indeed on their way out. The safeguards agreement provides for notification of VERs, notification by exporting (i.e., constrained) countries as well as by importing countries. Except for Nigerian restrictions on grain and kaolin imports, for which no elimination date was specified, all notified restrictions will be eliminated by the end of 1999 .

As to remaining NTBs of other forms (e.g., restrictive import licensing procedures, price control measures) a 1997 OECD survey of its members found such measures on a small percentage of tariff lines -4 percent or lower for the OECD countries covered in the survey. A similar tabulation of NTB incidence among developing economies based on information from WTO Trade Policy Reviews indicates a wider range of NTB incidence among these countries. For Hong Kong and for Singapore, the tabulation found virtually no NTBs, for Brazil, India and Indonesia a relatively high number. The tabulation also indicates that Latin American countries

\footnotetext{
${ }^{46} \$ 50 \times 10^{9}$.
} 
that have undertaken major tariff reductions in the past 10 or 15 years have also significantly reduced their NTBs - e.g., Argentina and Chile.

Some quantitative restrictions remain. Those related to the protection of human, animal and plant health, to the application of industrial standards, or to trade in arms and munitions are clearly GATT-legal. Agreements on the application at the border of health and industrial standards will facilitate the policing of the temptation to use such measures as disguised forms of protection. A few countries maintain restrictive measures under GATT provisions that allow such to protect the balance of payments, but continuing negotiating pressure has significantly reduced the application of such measures.

\section{TEXTILES AND CLOTHING}

A major accomplishment of the Uruguay Round is an agreement to eliminate the Multi Fiber Arrangement and an accompanying bound commitment by countries that now apply import quotas sanctioned by the MFA to eliminate these restrictions. In addition, the developed economies agreed to tariff cuts on textiles that are deeper than those on other industrial products.

The dark side of this accomplishment:

- The agreement is written in such a way that the developed economies will be able to legally put off elimination of MFA restrictions until 2005. While the provision of four "stages" suggests that 33 percent of the agreed liberalization should have been in place by the end of 1997 , in fact the US has eliminated only 1 percent of its MFA quotas, the EU 7 percent.

- Developed economies' tariffs on textiles and clothing remain two to three times higher than their tariffs on other industrial goods.

The agreement provides for the application of "transitional safeguards" (MFA-like restraints) on products not under such restraint when the agreement came into effect, but the use of these has been minimal. Three different importing countries through April 1999 have applied a total of 35 such measures; but as of April 1999, only two of these had not been rescinded.

\section{AGRICULTURE}

The major accomplishment of the agriculture agreement is the creation of a "tariffs only" regime - the replacement of all NTBs by tariffs plus the binding of all agricultural tariffs (those that replace NTBs as well as those on products previously protected only by tariffs.) This conversion to tariffs was accompanied by reductions of import protection levels that were narrower in scope, but deeper than tariff reductions on industrial products. A special safeguards provision, applicable only to tariffied products, has been minimally used.

A close look at implementation suggests however that the public relations dimensions of the agriculture agreement may have outpaced the substance of liberalization. While the further use of NTBs is explicitly banned, the conversion formulas for setting tariffs "equivalent" to the NTBs they replaced were negotiating guidelines, not legal obligations. ${ }^{47}$ Likewise, the often cited 36 percent cut by developed economies and 24 percent cut by developing economies were guidelines, not legal obligations - and could be made meaningless for tariffied products by the possibility of setting inflated tariff equivalents. Instances of such inflated tariff equivalents have

\footnotetext{
${ }^{47}$ Developing and developed economies alike were required to eliminate NTBs, but the negotiating guidelines allowed developing economies to apply ceiling bindings rather than tariffs equivalent to their NTBs.
} 
appeared in the press, e.g., Japan has set a specific tariff ${ }^{48}$ on rice that at present prices amounts to 1,000 percent, ad valorem. The post Uruguay Round tariff rates are lower than the tariff equivalent of pre- Uruguay Round protection for only 14 percent of products that underwent tarification.

Perhaps the most illiberal element in the WTO agricultural regime is the use of tariff quotas to implement minimum access provisions. Except for rice imports by Japan and Korea, the tariff quota system has had little effect on the amount of trade, and it has preserved the old system of political bargaining over the allocation among exporters of restricted import access managed trade, not liberalized trade.

The agriculture agreement provides for further negotiations, to begin in 2000 . Unlike the textiles and clothing agreement, the agriculture agreement includes no binding commitment for further removal of restrictions.

\section{ANTIDUMPING}

In the mid 1980s to early 1990s antidumping became the most popular tool for governments seeking a GATT-legal means to accommodate a domestic industry that was clamoring for protection. With the significant strides toward liberalization achieved at the Uruguay Round, including the banning of VERs (the favored instrument the previous decade), there were fears that antidumping would be even more intensely used.

To now, fears of such a surge have not been realized. The number of antidumping measures introduced by the traditional users (Australia, Canada, EU, US) has been less since 1995 than it had been in the years just before. A number of developing economies have however become major users - over 30 WTO members have notified antidumping actions since the Uruguay Round Agreements came into effect. Argentina, Mexico, Brazil and India have become major users, with numbers of cases per dollar of imports considerably higher than the ratios for traditional users.

China is the most frequent target for antidumping actions, followed by the United States. Per dollar of exports, antidumping initiations against an economy are much higher against developing economies. Thus the generalization that describes tariffs can be extended to antidumping: it is disproportionally used by developing economies, it is disproportionally used against developing economies.

Where antidumping duties have been applied, they have provided a degree of protection much higher than what was taken away by Uruguay Round tariff reductions. Antidumping duties of 30 to 50 percent are common, many are higher. By comparison, reductions agreed at the Uruguay Round were in the range of 2 to 4 percentage points.

\section{COUNTERVAILING DUTIES}

WTO Members take countervailing measures more often than safeguard actions under Article XIX, but not nearly so often as they use antidumping to protect local producers - in 1992-98, some 2,000 antidumping investigations initiated, 200 countervailing duty investigations. The number of countervailing duty cases dropped sharply in the first three years the Uruguay Round Agreements were in force, but incomplete information indicates that in 1998

\footnotetext{
${ }^{48}$ Per kilo, rather than ad valorem.
} 
the number of cases is back up to pre-1995 levels. The US is by far the largest user, more than 40 percent of initiations in the 1990 s were by the US. Developing countries, particularly Brazil, Chile and Mexico, are other frequent users.

\section{SAFEGUARDS}

The major accomplishment of the safeguard agreement is that it has been successful in curtailing protection outside the multilateral framework. VERs that existed when the agreement came into effect have been phased out, and through March 1999, there have been no complaints that the prohibition of gray area measures has been violated. Some WTO Members hoped that in lifting the compensation requirement on time-bound and degressive safeguard measures, the agreement would make safeguard measures more user friendly and perhaps shift usage away from antidumping. This seems not to have occurred - in 1995-98, when there were almost 900 antidumping initiations, only 19 safeguard investigations were initiated. In only one of the seven countries initiating safeguard investigations did the cases cover as much as $1 / 2$ of 1 percent of total imports.

Fourteen of the 19 safeguard initiations were by developing economies.

\section{SERVICES}

Since the Uruguay Round, the multilateral trading system includes disciplines and liberalization commitments covering trade in services. Although experts who have reviewed the outcome of the negotiations have concluded that the first round of services negotiations did not result in far-reaching trade liberalization, they also point out that the importance of bringing services under the multilateral umbrella of the WTO should not be underestimated. In most countries, at least half of GDP is generated in the services sector and the share is increasing. At the same time, less than one quarter of reported world trade is in services.

Overall, the Uruguay Round Agreements were a notable step toward opening world markets. Developing economies stepping forward as equal partners with the developing economies in working toward an open global trading system was an equally notable event. The Uruguay Round Agreements preserved and perhaps extended the provisions for imposing new trade restrictions, but so far resort to these provisions has been minimal. Since the entry into force of the Uruguay Round Agreements, use of traditional trade remedies - e.g., antidumping, countervailing duties - has been below rates in the decade before. Spread of use of antidumping to developing economies - the intensity of their use of this instrument, especially against imports from other developing economies - is however a matter of concern. 


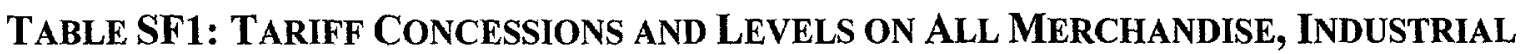
Goods, Textiles and Clothing, Agricultural Products - Developed ECONOMIES AND DEVELOPING ECONOMIES COMBINED

\begin{tabular}{|l|c|c|c|c|c|}
\hline & $\begin{array}{c}\text { Bindings, post } \\
\text { Uruguay } \\
\text { Round }\end{array}$ & \multicolumn{2}{|c|}{ Tariff reductions } & \multicolumn{2}{|c|}{$\begin{array}{c}\text { Post Uruguay Round } \\
\text { average tariff }\end{array}$} \\
\cline { 3 - 6 } & $\begin{array}{c}\text { \% of } 1989 \\
\text { imports }\end{array}$ & $\begin{array}{c}\text { Scope } \\
\% \text { of } \\
\text { imports }\end{array}$ & $\begin{array}{c}\text { Depth } \\
\mathrm{dT} /(1+\mathrm{T})\end{array}$ & Bound & Applied \\
\hline All merchandise & 97 & 30 & 1.2 & 7 & 4 \\
\hline Industrial goods & 91 & 32 & 1.3 & 6 & 4 \\
\hline Textiles and clothing & 80 & 53 & 1.6 & 12 & 10 \\
\hline $\begin{array}{l}\text { All Agricultural } \\
\text { products }\end{array}$ & 100 & 25 & 2.6 & 24 & 14 \\
\hline $\begin{array}{l}\text { Tariffied Agricultural } \\
\text { Products }\end{array}$ & 100 & 14 & 4.2 & 32 & 25 \\
\hline $\begin{array}{l}\text { Not tariffied agricultural } \\
\text { products }^{\mathrm{b}}\end{array}$ & 100 & 32 & 1.4 & 19 & 8 \\
\hline
\end{tabular}

Notes:

${ }^{a}$ Products protected before the Uruguay Round by NTBs - that were converted to tariffs.

${ }^{b}$ Products protected before the Uruguay Round by tariffs - with no NTBs to convert.

TABle SF3: Post URuguay Round TaRIfF RATES DeVeloped ECONOMIES AND DEVELOPING ECONOMIES - PERCENT AD VALOREM

\begin{tabular}{|l|c|c|c|c|}
\hline & \multicolumn{2}{|c|}{ Bound } & \multicolumn{2}{c|}{ Applied } \\
\hline & $\begin{array}{l}\text { Developed } \\
\text { economies }\end{array}$ & $\begin{array}{c}\text { Developing } \\
\text { economies }\end{array}$ & $\begin{array}{c}\text { Developed } \\
\text { economies }\end{array}$ & $\begin{array}{c}\text { Developing } \\
\text { economies }\end{array}$ \\
\hline All merchandise & 4 & 25 & 3 & 13 \\
\hline Industrial products & 4 & 20 & 3 & 13 \\
\hline Textiles and clothing & 11 & 24 & 8 & 21 \\
\hline Agricultural products $^{\mathrm{a}}$ & 15 & 60 & 14 & 18 \\
\hline
\end{tabular}

Note: ${ }^{a}$ Includes tariffied and not-tariffied products. 
TABLE SF2: SUMMARY OF URUGUAY ROUND CONCESSIONS BY DEVELOPED ECONOMIES AND BY DEVELOPING ECONOMIES

\begin{tabular}{|c|c|c|c|c|}
\hline & $\begin{array}{c}\text { All } \\
\text { merchandise }\end{array}$ & $\begin{array}{l}\text { Industrial } \\
\text { products }\end{array}$ & $\begin{array}{l}\text { Textiles } \\
\text { and } \\
\text { clothing }\end{array}$ & $\begin{array}{c}\text { All } \\
\text { Agricultural } \\
\text { products }\end{array}$ \\
\hline \multicolumn{5}{|l|}{$\begin{array}{l}\text { Bindings, post Uruguay Round - } \\
\% \text { of imports }\end{array}$} \\
\hline Developed economies & 89 & 92 & 80 & 100 \\
\hline Developing economies & 91 & 84 & 85 & 100 \\
\hline \multicolumn{5}{|l|}{ Uruguay Round Tariff Cuts } \\
\hline \multicolumn{5}{|l|}{ Scope - \% of imports } \\
\hline Developed economies & 30 & 32 & 53 & 26 \\
\hline Developing economies & 29 & 33 & 49 & 17 \\
\hline \multicolumn{5}{|l|}{ Depth $-\mathrm{dT} /(1+\mathrm{T})$ as $\%$} \\
\hline Developed economies & 1.0 & 1.0 & 1.4 & 1.5 \\
\hline Developing economies & 2.3 & 2.7 & 4.1 & 4.7 \\
\hline \multicolumn{5}{|l|}{$\begin{array}{l}\text { Post Uruguay Round average } \\
\text { tariffs - percent, ad valorem }\end{array}$} \\
\hline \multicolumn{5}{|l|}{ Bound } \\
\hline Developed economies & 4 & 4 & 11 & 15 \\
\hline Developing economies & 25 & 20 & 24 & 60 \\
\hline \multicolumn{5}{|l|}{ Applied } \\
\hline Developed economies & 3 & 3 & 8 & 13 \\
\hline Developing economies & 13 & 13 & 21 & 18 \\
\hline
\end{tabular}


TABLE SF4: PeRCENTAges OF ANTIDUMPING INITIATIONS, JULY 1996 - JUNE 1998 AGAINST DIFFERENT GROUPS OF ECONOMIES

\begin{tabular}{|l|c|c|c|c|}
\hline \multirow{2}{*}{ Initiating economy } & \multicolumn{4}{|c|}{ Targeted economy } \\
\cline { 2 - 5 } & China & Developed & Developing & Transition \\
\hline $\begin{array}{l}\text { Developed } \\
\text { economies }\end{array}$ & 19 & 31 & 40 & 11 \\
\hline $\begin{array}{l}\text { Developing } \\
\text { economies }\end{array}$ & 25 & 35 & 24 & 15 \\
\hline
\end{tabular}




\section{REFERENCES}

Adlung, R., A. Carzinaga and A. Mattoo (1999) "A Review of GATTS Commitments", forthcoming WTO Working Paper.

Bacchetta, M, P. Low, A. Mattoo, L. Schuknecht, H. Wager and M. Wehrens (1998) Electronic Commerce and the Role of the WTO, Geneva: World Trade Organization.

Commission of the European Communities (1994 and 1998) Report from the Commission to the European Pariiament on the Community's Antidumping and Anti-Subsidy Activities, Brussels.

Croome, John (1996) WTO Obligations and Bank Policy Advice: Keeping up with postUruguay Round Rules, Washington DC: The World Bank.

Croome, John (1998) The Present Outlook for Trade Negotiations in the World Trade Organization, World Bank Policy Research Working Paper 1992.

Finger, J. Michael (1996) "Legalized Backsliding: Safeguard Provisions in GATT" in Will Martin and L. Alan Winters (eds) The Uruguay Round and the Developing Countries, Cambridge: University Press, 316-340.

Finger, J. Michael (1998) GATT Experience with Safeguards: Making Economic and Political Sense of the Possibilities that the GATT Allows to Restrict Imports, Policy Research Working Paper No. 2000, Washington DC: The World Bank, October.

Finger, J. Michael (ed.) (1993) Antidumping: How it Works and Who Gets Hurt, Ann Arbor: University of Michigan Press.

Finger, J. Michael and Ann Harrison (1996) "The MFA Paradox: More Protection and More Trade?" in Anne O. Krueger (ed.) The Political Economy of American Trade Policy, Chicago: University of Chicago Press, 197-253.

Finger, J. Michael, Merlinda D. Ingco and Ulrich Reincke (1996) The Uruguay Round: Statistics on Tariff Concessions Given and Received, Washington, DC: The World Bank.

General Agreement on Tariffs Trade (GATT) (1993) Overview of Developments in International Trade and the Trading System, Annual Report by the Director General, Geneva.

Hathaway, Dale E. and Merlinda D. Ingco (1996) "Agricultural Liberalization and the Uruguay Round," in W. Martin and L. Alan Winters (eds.) The Uruguay Round and the Developing Countries, Cambridge: Cambridge University Press, 30-58.

Hoekman, Bernard (1996) "Assessing the General Agreement on Trade in Services," in Will Martin and L. Alan Winters (eds.) The Uruguay Round and the Developing Countries, Cambridge: Cambridge University Press, 88-124.

Hufbauer, Gary Clyde and Kimberly Ann Elliott (1994) Measuring the Costs of Protection in the United States, Washington DC: Institute for International Economics.

Ingco, Merlinda D. (1995) "Agricultural Trade Liberalization in the Uruguay Round," Policy Research Working Paper No. 1500, August, Washington DC: The World Bank. 
International Trade Reporter (1998) "Japan Decides Rice Tariffication of $\$ 3.05$ per Kilo Beginning in April 1999," v. 15, no. 50. (December 23) p. 2121.

Laird, Sam (1999) "Patterns of Protection and Approaches to Liberalization," paper presented at the CEPR Conference on New Issues in the World Trading System, London 2/1999.

Leidy, M. (1996) Macroeconomic Conditions and Pressures for Protection Under Antidumping and Countervailing Duty Laws: Empirical Evidence from the United States, IMF Staff Paper, Washington DC: International Monetary Fund.

Low, Patrick, A. Mattoo and L. Schuknecht (1999) "Trade Policies for Electronic Commerce," forthcoming WTO Working Paper.

Martin, Will and L. Alan Winters (eds.) (1996) The Uruguay Round and the Developing Countries, Cambridge: Cambridge University Press.

Messerlin P. (1989) "The EC Antidumping Regulations: A First Economic Appraisal, 198085," Weltwirtschaftliches Archiv, 125: 563-587.

Michalopoulos, Constantine (1999) "The Integration of Developing Countries into the Multilateral Trading System: Commercial Policy and Market Access," Geneva WTO Mimeo.

Miranda, J., R. Torres, and M. Ruiz (1998) "The International Use of Antidumping, 19871997," Journal of World Trade, 32: 5-71

OECD (1997) Indicators of Tariff and Non-Tariff Trade Barriers, Paris: Organization for Economic Cooperation and Development.

Snape, Richard (1998) Reaching Effective Agreements Covering Services, in Anne O. Krueger (ed.) the WTO as an International Organization, Chicago: The University of Chicago Press, pp. 287-289.

Staiger, R. and F. Wolak (1994) "Measuring Industry Specific Protection: Antidumping in the United States," NBER Working Paper No. 4696.

United Nations Conference for Trade And Development and World Trade Organization (1998) Market Access Development Since the Uruguay Round: Implications, Opportunities and Challenges, in Particular for Developing Countries and Least Developed Countries, in the Context of Globalization and Liberalization, Geneva Mimeo.

United States International Trade Commission (1998) US Antidumping and Countervailing Duty Handbook, October; Washington D.C.

WTO (1997) Trade Policy Review, United States 1996, Geneva: World Trade Organization, February.

WTO (1998) Trade Policy Review, Japan 1998, Geneva: World Trade Organization, June.

WTO Secretariat (1997) General Council Decision of 16 July 1997, WT/L/225, Geneva.

WTO Secretariat (1999) Guide to the Uruguay Round Agreements, Kluwer Law International, The Hague, London, Boston.

Zdouc, W. (1999) "WTO Dispute Settlement Practice Relating to the GATS," Geneva: WTO Mimeo. 


\section{Policy Research Working Paper Series}

Title

WPS2214 Trade Policy and Market Access Issues for Developing Countries: Implications for the Millennium Round

WPS2215 Implementation of Uruguay Round Commitments: The Development Challenge

WPS2216 Corruption and Trade Tariffs, or a Case for Uniform Tariffs

WPS2217 Border, Border, Wide and Far, How We Wonder What You Are

WPS2218 Who Avoids and Who Escapes Poverty during the Transition: Evidence from Polish Panel Data, 1993-96

WPS2219 The Effect of the United States' Granting Most Favored Nation Status to Vietnam

WPS2220 A Quantitative Evaluation of Vietnam's Accession to the ASEAN Free Trade Area

WPS2221 The Dynamics of Poverty and the Effectiveness of Poland's Safety Net (1993-96)

WPS2222 Labor Market Integration in the Presence of Social Capital

WPS2223 Integrated Financial Supervision: Lessons from Northern European Experience

WPS2224 Growth Forecasts Using Time Series and Growth Models

WPS2225 How Did Highly Indebted Poor Countries Become Highly Indebted? Reviewing Two Decades of Debt Relief

WPS2226 Money, Politics, and a Future for the Michael Klein international Financial System
Author Date

Constantine Michalopoulos October 1999

J. Michael Finger

Philip Schuler

October 1999

L. Tabada

36896

Roberta Gatti

October 1999

R. Gatti

38735

David C. Parsley

November 1999

H. Sladovich 37698

Wlodzimierz Okrasa

November 1999

S. Fallon 38009

Emiko Fukase

Will Martin

November 1999

L. Tabada 36896

Emiko Fukase

Will Martin

November 1999

L. Tabada 36896

Wlodzimierz Okrasa

November 1999

S. Fallon 38009

Maurice Schiff

November 1999

L. Tabada 36896

Michael Taylor Alex Fleming

November 1999

S. Torres 39012

Aart Kraay

November 1999

R. Bonfield George Monokroussos

William Easterly

November 1999

K. Labrie 31001

November 1999

M. Salehi 37157 


\section{Policy Research Working Paper Series}

Title

WPS2227 The Sri Lankan Unemployment Problem Revisited

WPS2228 Fiscal Contingency Planning for Banking Crises

WPS2229 Do School Facilities Matter? The Case of the Peruvian Social Fund (FONCODES)

WPS2230 Bankruptcy Organization through Markets: Auction-Based Creditor Ordering by Reducing Debts (ACCORD)

WPS2231 What's Behind Mercosur's Common External Tariff
Author

Martin Rama

Patrick Honohan

Christina Paxson Norbert Schady

David Hausch

S. Ramachandran

Marcelo Olarreaga

Isidro Soloaga

L. Alan Winters
Date

November 1999

November 1999

November 1999

L. Tsang

80516

S. Fallon 38009 38526 88247
Contact for paper

A. Yaptenco

N. Schady

November 1999 L. Tabada 35555

1120 